I N T ER N ATIONAL MONETARY FUND

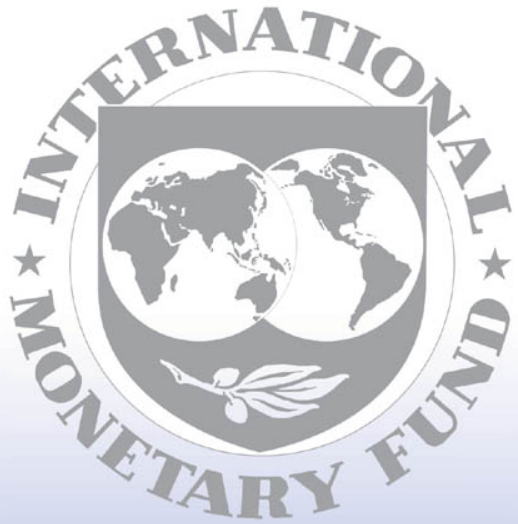

Staff

Country

Reports 


\title{
Iceland: Staff Report for Second Review Under Stand-By Arrangement and Request for Extension of the Arrangement, Rephasing of Access and Establishment of Performance Criteria.
}

The following documents have been released and are included in this package:

- $\quad$ The staff report, prepared by a staff team of the IMF, following discussions that ended on December 15, 2009, with the officials of Iceland on economic developments and policies. Based on information available at the time of these discussions, the staff report was completed on April 8, 2010. The views expressed in the staff report are those of the staff team and do not necessarily reflect the views of the Executive Board of the IMF.

- $\quad$ A Press Release.

- $\quad$ A statement by the Executive Director for Iceland.

The document(s) listed below will be separately released.

Letter of Intent sent to the IMF by the authorities of Iceland*

Technical Memorandum of Understanding*

*Also included in Staff Report

The policy of publication of staff reports and other documents allows for the deletion of market-sensitive information.

\author{
Copies of this report are available to the public from \\ International Monetary Fund • Publication Services \\ $70019^{\text {th }}$ Street, N.W. • Washington, D.C. 20431 \\ Telephone: (202) 623-7430 • Telefax: (202) 623-7201 \\ E-mail: publications@imf.org Internet: http://www.imf.org
}

\section{International Monetary Fund Washington, D.C.}




\title{
INTERNATIONAL MONETARY FUND
}

\section{ICELAND
Second Review Under the Stand-By Arrangement and Request for Extension of the Arrangement, Rephasing of Access, and Establishment of Performance Criteria

\author{
Prepared by the European Department in Consultation with Other Departments
}

Approved by Poul M. Thomsen and Aasim Husain

April 8, 2010

- Stand-By Arrangement: A 24-month SBA in an amount equivalent to SDR 1.4 billion (\$2.1 billion, 1190 percent of quota) was approved by the Executive Board on November 19, 2008 (Country Report No. 08/362). A first purchase of SDR 560 million was made following the Board meeting. The first review, along with an extension of the arrangement to May 31, 2011 and rephasing of access, was approved by the Executive Board on October 28, 2009 (Country Report No. 09/306). A second purchase equivalent to SDR 105 million was made following the completion of this review. The third purchase, equivalent to SDR 105 million, would become available upon completion of the second review, while the rest of undisbursed amounts are proposed to be rephased. To account for delays the authorities are requesting an extension of the arrangement to end-August 2011. The Nordic countries and Poland have also committed to provide funds to cover the financing gap under the program.

- Summary: Indications are growing that Iceland's recession, while deep, will be less severe than expected. Program policies have contributed to this, and all relevant performance criteria for the second review have been met. A recovery is still expected to commence in 2010, but it will face headwinds from the private sector debt overhang (and estimates of private sector external debt were again revised up), and from fiscal consolidation. The discussions focused on how to best support the recovery while meeting fiscal sustainability and financial sector restructuring objectives. In this context, the authorities and staff agreed that a better outlook for public sector debt would allow a slightly more gradual fiscal consolidation in 2010; and that to address the private sector debt overhang, private sector debt restructuring needed to be accelerated. The authorities also took actions to directly address program fiscal and financial sector objectives. Landsbankinn (i.e. New Landsbanki) was recapitalized, and with the recapitalization of the savings banks all but complete, the first stage of the bank restructuring process is reaching an end. In addition, a medium-term strategy for public debt management was articulated; supervisory and regulatory reforms were put into draft legislation; and a process was designed to strengthen non-bank financial institutions. The central bank also took steps to support the krona, by tightening the administration of capital controls, which opened up room for interest rate cuts in support of the economy. Financing assurances are in place. In view of lingering uncertainties about the precise timing of external financing, it was agreed the monetary policy would need to place greater emphasis on reserve accumulation.

- Discussions. See Fund Relations Appendix. 
I. Introduction .

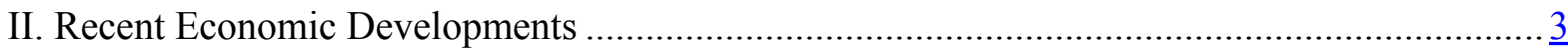

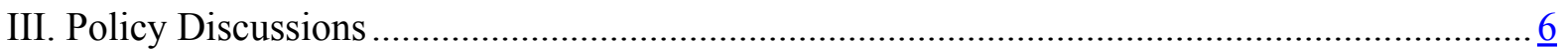

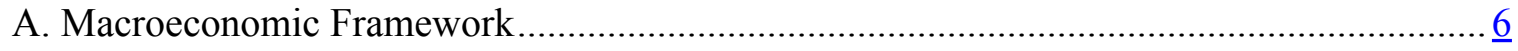

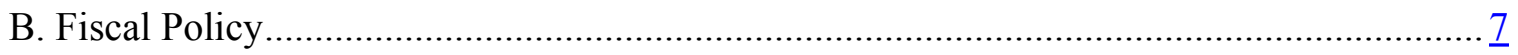

C. Monetary and Exchange Rate Policy ........................................................................

D. Financial Sector Policies ..................................................................................... $\frac{10}{13}$

E. Private Sector Debt Restructuring ..................................................................... 13

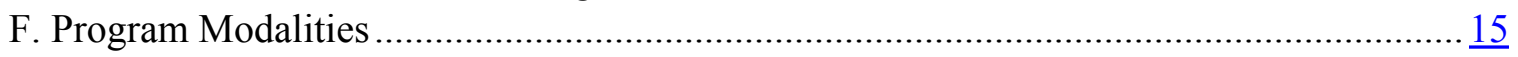

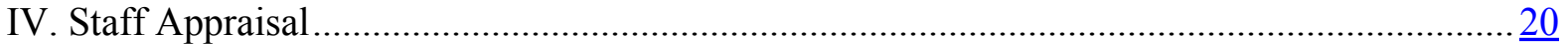

Figures

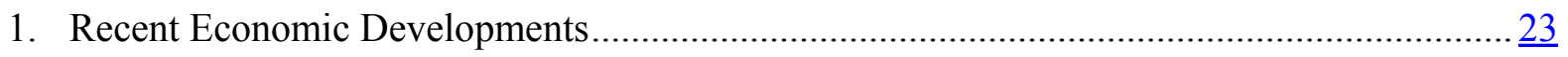

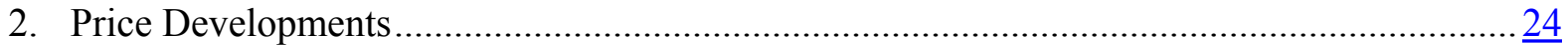

3. Financial Markets Developments …......................................................................... 25

4. Household and Corporate Sector Conditions ............................................................ 26

5. Macroeconomic Outlook Compared to the $1^{\text {st }}$ Review ..................................................... 27

6. GDP Growth and Export Performance ....................................................................... 28

7. Structure of Fiscal Adjustment and International Comparisons......................................... 29

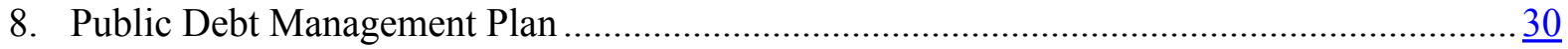

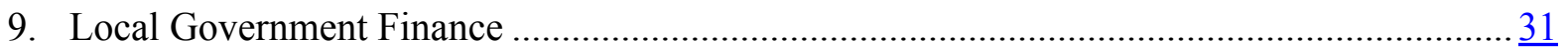

Tables

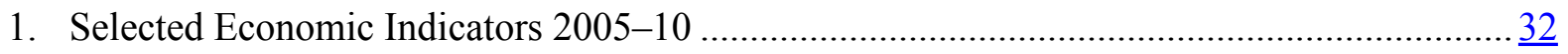

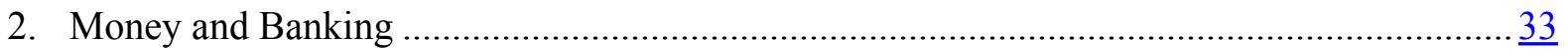

3. Status of the Financial Sector ................................................................................... 34

4. Projected External Debt Stock (gross), end-2009 ........................................................ $\underline{35}$

5. Medium-Term Projections, 2008-14 ........................................................................ 36

6. Balance of Payments, 2007-14 .................................................................................. $\frac{37}{38}$

7. General Government Operations 2007-14 (GFS, modified cash, percent of GDP) ............... $\underline{38}$

8. Central Government Operations 2007-14 (GFS, modified cash, percent of GDP) …............ $\underline{39}$

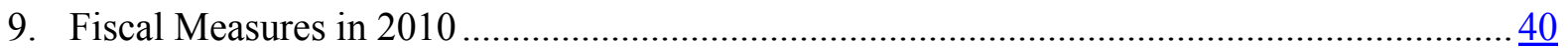

10. Changes to Capital Controls Rules............................................................................. 41

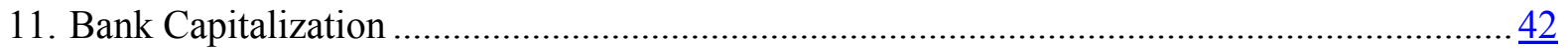

12. Current Household Debt Restructuring Framework.................................................... 43

13. Corporate Debt Restructuring Framework ....................................................................... 44

14. Proposed Changes in the Insolvency Regime …........................................................ 45

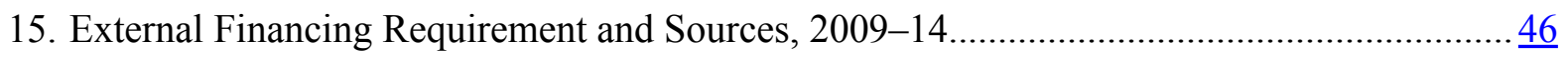

Appendix

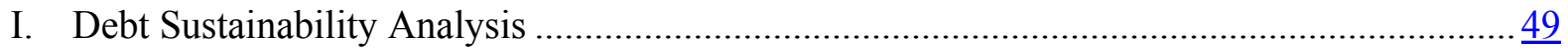

Attachments

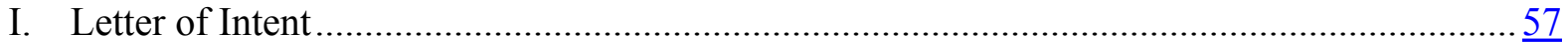

II. Technical Memorandum of Understanding ....................................................................... 69

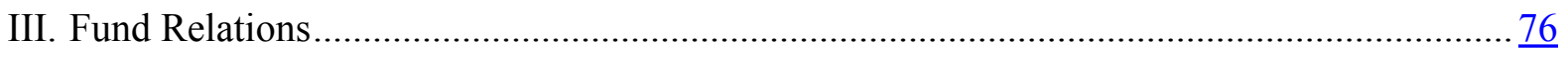




\section{INTRODUCTION}

\section{The policy agenda in Iceland continues to be overshadowed by the Icesave}

dispute. When Landsbanki failed during Iceland's October 2008 crisis, and Iceland's private deposit insurance fund was unable to pay claims, the U.K. and Netherlands stepped in to pay out deposit insurance obligations to depositors in "Icesave" branches. The sides have been trying ever since to reach an agreement on how to resolve the deposit insurance claims, now largely held by the U.K. and Netherlands (in the place of their depositors). A government-togovernment agreement, involving an Icelandic government guarantee of full recovery of deposit insurance claims, was reached during October 2009, and passed by Iceland's parliament. However, in March 2010 it was put to a referendum and resoundingly rejected.

\section{The need to reassess financing assurances contributed to a delay in the second} review. Bilateral program financing from the Nordic countries has been linked to progress towards resolving the Icesave issue. Staff was comfortable that the program was fully financed for the next 12 months, due to a current account surplus in the presence of capital controls. However, the uncertainty introduced by the evolving Icesave negotiations meant that a new assessment of medium-term financing was necessary. It is staff's assessment that financing assurances are in place: the Icelandic authorities have reaffirmed their intent to reach a settlement and unlock bilateral financing.

3. Policy implementation is on track despite some delays (LOI 1-2). Three program benchmarks are now complete, although two were implemented with delay (the public debt management strategy, for instance, was approved in early February). The fourth structural benchmark - recapitalization of the savings banks - is now nearing completion. All relevant performance criteria, including end-December quantitative targets, have been met. Overall, program objectives are being met: the krona has been steadily strengthening since the first review; the government has taken an important step towards securing fiscal sustainability with the passage of the 2010 budget; and bank restructuring is approaching a critical milestone, the full recapitalization of the system.

\section{RECENT ECONOMIC DEVELOPMENTS}

4. The macroeconomic adjustment of the economy continues to be less severe than expected (Table 1; Figures 1-2). The decline in real GDP amounted to $6 \frac{1}{2}$ rather than the originally projected $9 \frac{1}{2}$ percent in 2009 , and the seasonally adjusted unemployment rate has now stabilized in the 8-10 percent range. Supportive fiscal policies have helped consumption hold up better than expected, while the external sector has benefited from currency depreciation and higher commodity prices. The overall improvements in inflation and the trade and current account balances since the late 2008 crisis have been striking. Indicators currently suggest firming consumer sentiment, and stable inflation expectations, but still weak business sentiment. 
5. Financial markets remain stable but subdued (Table 2; Figure 3). Deposits have remained stable, reflecting the government's blanket guarantee. The exchange rate has appreciated from 186 to 172 krona per euro since November, even while the CBI has not intervened. Spreads in the offshore market have increased but offshore trading has thinned, reflecting tighter administration of capital controls. Short-term Interbank market interest rates have stayed in the 8-10 percent range and there has been little change in the yield curve since mid-October, reflecting broad stability in the CBI's effective policy rate (the CD rate, which has moved from about 10 to 9 percent). CDS spreads on Icelandic government debt increased in the wake of Icesave difficulties, and after a downgrades by Moody's and Fitch (Iceland is now positioned at or just below the lowest investment grade, by the ratings agencies). However, the spreads have since come back down and remain well below the immediate post-crisis level.

6. New information about private sector balance sheets suggests that vulnerabilities for the economy may be slightly less than previously perceived (Figure 4):

- In the corporate sector, the level of leverage is high, but FX exposures are concentrated. End-January 2010 data shows the level of non-performing loans at 50 percent for the corporate sector, and 41 percent for small and medium sized enterprises (SMEs). Most holding companies, where FX exposures are concentrated, have already defaulted (with limited impact on the real economy). Remaining FX borrowers are mostly exporters with some hedges, and over half of all Icelandic businesses have no FX liabilities. After long delays in establishing their balance sheets, commercial banks have recently started to adopt voluntary out-of-court workouts as a more permanent solution to distressed corporate debt.

- In the household sector a minority of loans are distressed, while FX exposures are less than feared. New data on non-performing loans confirm earlier CBI estimates about the level of distress (about 30 percent of retail loans under ISK 100 million at the banks are in default while about 15 percent of loans at the Housing Finance Fund (HFF) are in default or under payment suspension). The distress is concentrated among a small number of individuals, many of whom have direct FX exposures. Overall, however, only 9 percent of households have FX mortgage debt, and FX auto-loans are a small portion of total indebtedness. Nonetheless, indirect exposures to the exchange rate, through CPI-indexed debt, remain high. The debt restructuring framework for households, approved in October 2009, provides payment mitigation tools to alleviate the distress.

- In the financial sector, recapitalization has improved bank balance sheets, but challenges facing some non-deposit taking institutions have become clearer (Table 3). The three new commercial banks have now been recapitalized, with the government remaining the controlling party only in Landsbankinn (i.e., after allowing creditors to acquire its stake in the two other banks). Savings banks are in the process 
of being recapitalized. However, capital shortages in some non-banks have come to light, and the government owned and guaranteed HFF shows very high leverage (almost 60 times equity) and a capitalization ratio that has fallen to 4.3 percent at endJune 2009 (slightly above the locally-prescribed minimum of 4 percent). The issue of banks' long FX position is being addressed, and the banks are currently offering unhedged borrowers the conversion of their FX debts into ISK (with the FME supporting the effort by temporarily allowing the exclusion of such loans from the computation of their long foreign exchange position and market risk).

Table. FX Imbalances in the New Banks

\begin{tabular}{lccc}
\hline \multicolumn{1}{c}{ Bank } & Dec-08 & Jun-09 & Sep-09 \\
\hline & \multicolumn{3}{c}{ in percent of total equity } \\
\cline { 2 - 4 } Islandsbanki & 259 & 223 & 267 \\
Arion (New Kaupthing) & 301 & $\ldots$ & 287 \\
Landsbankinn (New Landsbanki) & 171 & 149 & 149 \\
\hline Source: FME & & &
\end{tabular}

7. General government debt is climbing more slowly than expected. At end-2009, the debt stood at 105 percent of GDP, about 15 percent of GDP lower than expected (i.e. excluding impacts due to delayed bilateral loans). Creditor acquisition of the government share in Arion and Islandsbanki has helped, along with sale of some financial assets acquired as collateral during the crisis. The expected Icesave obligation of the public sector, which is included in the debt estimate, continues to be between 15 and 20 percent of GDP (based on the October agreement). Higher projected asset recovery has been broadly offset by a slower expected rate of payout (as litigation is first allowed to play out). Ongoing renegotiations, which include an interest holiday for some years, suggest that the ultimate cost could be significantly lower.

Iceland: General Government Debt Indicators (in percent of GDP)

\begin{tabular}{|c|c|c|c|c|c|}
\hline & \multicolumn{2}{|c|}{2008} & \multicolumn{3}{|c|}{2009} \\
\hline & First Review & Est. & Prog. & Final & Difference \\
\hline Gross debt & 70.0 & 71.7 & 125.2 & 105.1 & -20.1 \\
\hline \multicolumn{6}{|l|}{ of which: } \\
\hline Bank recapitalization $1 /$ & 0.0 & 0.0 & 20.3 & 12.1 & -8.2 \\
\hline Net present value of IceSave guarantee & 0.0 & 0.0 & 17.2 & 17.0 & -0.3 \\
\hline Bilateral loans 2/ & 0.0 & 0.0 & 8.2 & 3.0 & -5.2 \\
\hline Local government debt & 6.6 & 8.3 & 8.2 & 10.0 & 1.8 \\
\hline Other & 63.4 & 63.3 & 71.3 & 63.1 & -8.2 \\
\hline Liquid Assets 3/ & & & 35.7 & 32.2 & -3.5 \\
\hline Net debt & 41.3 & 42.1 & 89.5 & 72.9 & -16.6 \\
\hline
\end{tabular}

$1 /$ Recapitalization of savings banks is now expected in 2010.

2/ Timing of bilateral loans updated in 2009 projections.

3 / Includes government deposits at $\mathrm{CBI}$, other deposits, and claims on $\mathrm{CBI}$ from onlent foreign exchange loans. 
8. External debt is broadly the same as previously projected, at about 300 percent of GDP at end-2009 (Table 4 and A1). For private sector external debt, some components have been revised down to reflect experience to date with cases already in bankruptcy or restructuring, but on net there is a significant increase, reflecting old bank assets now understood to have a domestic recovery source (for instance, derivatives, and loans that were put into offshore special purpose vehicles). Some uncertainty about overall external debt remains, reflecting the tangled pre-crisis web of cross-border transactions.

\section{Policy Discussions}

9. Discussions focused on securing Iceland's economic recovery. While the economy has performed better than expected to date, there is some risk that the debt overhang will trap the economy into a period of low growth. It was agreed that meeting the program's fiscal sustainability and financial restructuring objectives remained crucial to unlocking a sustainable medium-term recovery. However, it was also agreed that the near-term recovery could be supported by a slightly less front-loaded fiscal adjustment than originally planned (taking advantage of the better outlook for public debt), and by efforts to accelerate private sector debt restructuring (to directly address the private sector debt distress).

\section{A. Macroeconomic Framework}

10. Under the revised policy framework a gradual recovery, beginning in mid-2010, is still anticipated ( $\mathrm{LOI} 5$; Tables 5-6; Figures 5-6).

- $\quad$ Regarding growth, delays in energy-intensive investment projects dampen immediate prospects, but the recalibration of fiscal policy in 2010 and private sector debt restructuring are expected to partly offset the impact. The overall pattern of recovery, however, is expected to remain much the same: a strong contribution from net exports (due to import compression in the near-term and, over the medium-term, expanding exports including from non-traditional sectors, as the supply response builds); rising investment, as firms shake off credit constraints and exploit improvements in their competitiveness; and ultimately a broader recovery of domestic demand, as income filters down to households, and balance sheets recover. This is a pattern of recovery familiar from other countries' post-crisis experience, but program projections stretch out the timeframe given the more pronounced credit and supply-side constraints that Iceland faces (i.e. on the supply side, the quotas in the fishing industry and long lead times for new investments in the energy intensive sector).

- CPI inflation is now projected to be higher in 2010, reflecting delays to date in the disinflation process, and the shift of some indirect tax increases from late 2009 into 2010. The combination of slack in the economy, currency stability, and wage moderation is still expected to keep CPI inflation on a steady downward path, reaching 4-5 percent by end-2010, and 3-4 percent in 2011. 
11. There are headwinds to the recovery, although some upside is also possible. The main short-run risks are further delays in investments in energy-intensive sectors, high fiscal multipliers (to the extent that the distressed private sector cannot offset the impact of necessary fiscal restraint on domestic demand), and possible emigration. Constraints on the reallocation of resources from non-tradable to tradable sectorslack of financing and certain aspects of regulatory policies - may impede recovery in the medium term. On the other hand, there is ample potential for higher FDI in response

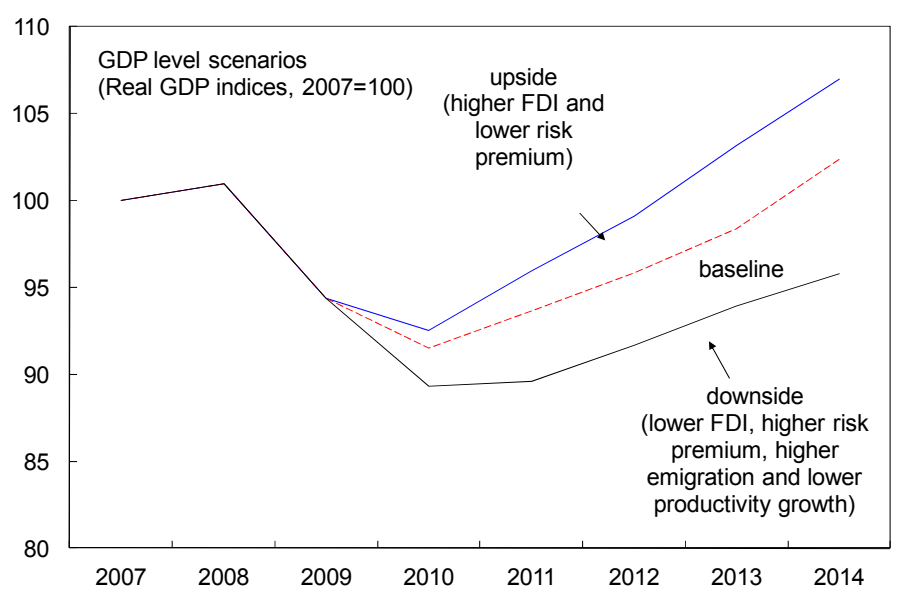
to the improvements in competitiveness. And program projections for current account related income receipts are very conservative (and to the extent they are higher, this would mean less pressure for adjustment through the trade balance, more real appreciation, and a balance sheet related boost).

12. While debt levels remain very high and are still a matter of concern, the revised debt numbers do not materially affect the sustainability assessment (LOI 6; Appendix I; Tables A1-A2; Figures A1-A2):

- $\quad$ External debt is projected to peak in 2010 at about 300 percent of GDP. It is projected to decline thereafter, although more slowly than previously foreseen owing to, among other factors, a revised timing of payments to creditors by old banks, revised FDI forecasts (more is now expected to be debt-financed), and updated forecasts of the disbursement and repayment of bilateral support. The main result — a declining debt ratio - continues to hold under most shocks, including a further increase in debt. However, significant, permanent real depreciation would represent a problem.

- $\quad$ The outlook for public debt sustainability has improved, and the medium-term trajectory benefits from the now-higher estimated recovery on assets acquired during the financial crisis. The steady downward path remains robust to shocks, including the downside 'headwind' scenario. However, stress tests signal that program fiscal consolidation targets need to be met, and contingent liabilities well-managed, to keep debt on a downward path.

\section{B. Fiscal Policy}

13. The authorities and staff agreed that the improved public debt outlook created room to support growth by slowing the pace of fiscal consolidation (LOI 8; Tables 7-8; Figure 7). Accordingly, the general government primary balance is expected to improve by 
$4 \frac{1}{4}$ percent of GDP during 2010 , as opposed to the $5 \frac{1}{2}$ percent of GDP previously programmed. The primary balance would still reach the previously programmed level of $23 / 4$ percent of GDP, owing to fiscal over performance in 2009 . The consolidation path would also remain frontloaded and in line with the pace of other Nordic consolidations, and would still deliver end-2014 public debt below the earlier estimate. Given stable local government budget plans the adjustment would be delivered by the central government.

\section{The authorities have passed a 2010 budget in line with the targeted adjustment.}

The budget reflects the earlier agreement with social partners in the context of the June stability pact: a mix of primary revenue and primary spending measures split about evenly. The measures required amounted to 5.4 percent of GDP, a little more than the total adjustment in light of the cyclical impact on tax revenues in 2010, and the introduction of a few new spending programs. They have been drawn from the authorities' medium-term consolidation plan (Table 9; Figure 7):

- Revenue measures amount to 2.5 percent of GDP. The authorities aim has been to increase the relative tax burden on high-income individuals, adjust for past tax erosion, target environmental externalities, and adjust earmarked taxes to spending needs (e.g. higher social contributions to finance high unemployment outlays). Most of the measures represent permanent changes, but about 0.4 percent of GDP are temporary (e.g. pre-payment of taxes), increasing the amount of measures needed in 2011 and beyond.

- $\quad$ Expenditure measures amount to about 3.2 percent of GDP. The authorities reiterated that their aim is to preserve the Iceland's Nordic model welfare state. Wages and transfer payments have been restrained via changes in indexation provisions, but the authorities pointed out that this would keep public sector wage developments in line with private sector developments. Welfare programs have been maintained, and in some cases new spending has been introduced to address vulnerable groups (e.g. young adults at the point of entering the labor market). The cuts fall mainly on operational and investment spending, where real increases had been very sharp in recent years.

\section{The work towards identifying fiscal measures for 2011-13 will continue during}

the next 6 months. The authorities' medium-term plan already identifies additional revenue options, but the authorities have also requested technical assistance from the Fund to facilitate continued work to improve the underlying structure of taxation. The authorities acknowledged that further work would be required to identify areas for spending adjustment. To begin the process, they expected to submit medium-term expenditure ceilings consistent with the medium-term consolidation plan, and binding for the first two years, to cabinet for approval during the first half of the year. 
16. The authorities and staff agreed that public debt management had a key role to play in securing fiscal sustainability (LOI 9). To this end, and building on technical assistance provided by the Fund, the authorities articulated a medium-term debt management strategy. The strategy, among other initiatives, aims for: a higher share for krona-denominated debt; establishment of a few liquid benchmark issues along the yield curve; the introduction of long-term inflation-indexed bonds to widen the investor base; disposal of financial assets accumulated during the crisis; and the maintenance of a sufficient deposit buffer. Successful implementation would increase the average maturity of Iceland's debt to $4 \frac{1}{2}$ years by 2011 (from below 31/2 years at end 2009, and just 2 years after the crisis), smooth the profile of debt coming due, and provide a significant buffer against adverse developments in sovereign debt markets (deposits targeted at no less than 6 months of government debt amortization; the present figure is 12 months) (Figure 8). Lower rollover risk, in turn, could eventually contribute to a lower risk premium. The strategy also recognizes the need to build up capacity in the Ministry of Finance for this function (the current model, where the central bank largely handles the work, is best suited to countries with low debt where the main objective is to build up a yield curve).

17. The authorities plan to strengthen the fiscal federal framework (LOI 10). They recognized that, in comparison to their OECD peers, local governments in Iceland were a large element of general government, with a high degree of fiscal autonomy, but a very volatile revenue base. At the same time the framework for coordination, monitoring and control was among the weakest in the OECD (Figure 9). To contain risks, improve coordination, and facilitate more equal distribution of the fiscal adjustment burden, the authorities indicated that they intend to amend the fiscal framework. To this end, a Committee has been established which is due to report its findings by mid 2010, allowing amendments to be passed into law in time for the new fiscal year (proposed as a new program structural benchmark for end-2010). In terms of new municipal fiscal rules, international experience provides several models for the authorities to consider, including borrowing or debt limits, deficit rules (e.g. Spain), and targets for the sector that are backed by political commitment (e.g. Belgium in the 1990s).

\section{Monetary and Exchange Rate Policy}

18. The authorities and staff agreed that currency stability remains the appropriate intermediate target towards program inflation and growth objectives. (LOI 11). The Monetary Policy Committee (MPC) has stated that it stands ready to adjust the monetary stance as required to maintain exchange rate stability, within a flexible exchange rate regime. To the extent the krona strengthens, spreads on Icelandic debt decline, and inflation continues to subside, there may be room to reduce interest rates. In such a context, negative feedback through balance sheet channels would be minimal, and the lower rates could thus help address the output gap, improve public and external debt dynamics, and facilitate private sector debt restructuring and the correction of banks' FX long positions (by inducing a shift into krona loans). However, it was also recognized that Iceland had to build up its net 
international reserves over time to fully extricate itself from the 2008 crisis. Given present uncertainties over the timing of new external borrowings, it was agreed that, in the event of a strengthening krona, emphasis also had to be placed on reserve accumulation.

19. Monetary operations have been adjusted to increase the effectiveness of interest rate policy (LOI 12). Auctions of 28-day Certificate of Deposits (CDs), introduced in September, have drained excess liquidity from the market and brought short-term market interest rates within the CBI's rate corridor. To ensure that policy rates continue to feed through to the financial markets, and that the stance of monetary policy is well-understood, the authorities reduced the corridor from $500 \mathrm{bps}$ at end-September to $300 \mathrm{bps}$ in December, eliminated the minimum $\mathrm{CD}$ rate, and restructured $\mathrm{CD}$ auctions to feature a pre-announced weekly volume target (set according to the CBI's liquidity forecast with all bids up to the targeted volume accepted).

\section{To support the krona, the authorities have tightened the administration of} capital controls, while the next liberalization steps remain on hold (LOI 13). At endOctober 2009, administration was tightened, and resources were added to the CBI's surveillance unit (Table 10). Since this point, the currency has steadily gained ground, and the CBI has been able to cease its previously small but steady interventions in the market. Administration nonetheless remains a challenge, and it was agreed that additional resources may yet be needed to address bottlenecks in the investigation and prosecution processes and to enhance data collection and monitoring in the CBI. Also in October 2009, the CBI lifted controls on all new inward investment in foreign exchange, although the impact of this has been slight to date. However, it was agreed that the liberalization of capital outflows would not commence at present, in light of the BoP outlook (especially uncertainty about the timing of new external borrowing), and the incomplete operational restructuring of the financial sector (key preconditions stated in the liberalization strategy).

\section{Financial Sector Policies}

21. The authorities and staff agreed that the key near term priority was to wrap up bank recapitalization (LOI 14). Recapitalization would underpin greater confidence in the banks, remove an important impediment to private sector debt restructuring (banks would know their balance sheet), and set the stage for operational restructuring, in particular reductions in FX and CPI indexed exposures. The focus was twofold (Table 11 describes the outcomes in more detail):

- Landsbankinn. The bank was recapitalized on December 15, 2009, after the FME confirmed that asset valuation was in line with industry standards.

- $\quad$ Savings banks. Due diligence by the FME, supported by independent audits, revealed that seven out of the ten remaining savings banks were severely undercapitalized or insolvent, and all had obligations with the CBI (by dint of assets 
absorbed during last year's bank interventions). In all of these cases, deadlines were extended to allow sufficient time for negotiations between bank creditors and bank owners, and to allow the two parties time to come up with proposals that did not require the government to absorb losses (as initial proposals did) .

- $\quad$ By end-March 2010 the smallest eight savings banks agreed with the central bank on recapitalization plans, which include the restructuring of their debt through rescheduling, write downs, and debt to equity swaps. The CBI will participate in 5 of these cases, and indicated that all equity acquired would be transferred to the State Banking Agency for management

- $\quad$ The two larger savings banks' owners have also reached preliminary agreements with their creditors, which entail capital injections by the government to the limit defined in the Emergency Law, and in line with conditions applied by the government (including, in the first place, the allocation of losses to owners and creditors). A decision by owners and creditors remains to be taken, and the authorities indicated that if this latest round of negotiations did not reach a conclusion, timely resolution of these weak institutions would be needed through a mechanism that protects depositors in full. In either case, full recapitalization of the sector is now expected by end-May (proposed as a new program structural benchmark).

\section{The authorities agreed that an important priority would be to reduce} vulnerabilities in the non-bank financial sector (LOI 15). The sector is large: assets of some 50 percent of GDP in the Housing Finance Fund (HFF) and almost 20 percent of GDP in other credit undertakings. While assets from commercial and savings banks have been subject to stringent forward-looking valuations that have led to recognition of large losses, the rest of the system has yet to be put to similar scrutiny. These institutions do not take deposits from the public - they borrow in the capital markets. Among them, the HFF is thought to have better overall portfolio quality than the banks, as it did not engage in the riskiest forms of mortgage lending.

\section{The discussions identified a process by which to address non-banks'}

vulnerabilities. All of these institutions will be required, on the basis of their end-2009 books, to demonstrate that their business plans are sufficient to maintain or restore their solvency and viability without government support. The FME would review the plans and require remedial measures as necessary (proposed as a new structural benchmark for endAugust 2010). For the private undertakings, the authorities reiterated their program principles not to absorb losses and to treat creditors fairly according to applicable law. For the government-owned HFF, the debt of which is also government guaranteed, the authorities indicated that there was no reason to yet believe a government capital injection would be required. However, the broader issue of the prudential rules to be applied, including a higher 
capital ratio consistent with Basel requirements, would have to be addressed, with gradual phase-in.

\section{The authorities have submitted legislation to parliament to address weaknesses \\ in the bank regulation and deposit insurance framework (meeting an end-December structural benchmark) (LOI 16):}

- $\quad$ The draft changes to the banking act address a number of issues raised in the earlier Jännäri Report, including the discretionary powers of the FME; the establishment of a national credit registry at the FME (that will cover significantly-sized loan exposures); tougher provisions on large exposures, connected lending, and related party loans (including mandatory approval of the latter by bank board members); fit and proper requirements for owners; and cooperation of the FME with external auditors. The changes are expected to diminish credit risk in the system, provide a better overview of large exposures at the national level, and enhance the supervisory and regulatory capacity of the FME.

- $\quad$ The draft bill on deposit insurance (DIS) closely follows recent developments within the EU. The authorities and staff agreed that (i) the DIS must protect a large number of depositors to be effective; (ii) banks should be given sufficient time to absorb the increase in their contributions to the system; and (iii) in certain circumstances the DIS could borrow to ensure that it has sufficient resources to ensure prompt repayment of domestic deposits. The deposit insurance limit in Iceland would be raised to euro 50,000 . However, especially given the ongoing discussions to strengthen the savings bank sector, the staff and authorities agreed that this was not the time to remove the government's existing blanket deposit guarantee. Thus, it was announced that such protection would remain in place and its gradual lifting will be announced once market confidence in banks has been completely restored.

\section{Further actions are planned to strengthen the regulatory and supervisory}

framework (LOI 17). The FME indicated that upon passage of the draft legislation it would use its enhanced powers to update prudential guidelines. Looking forward, it was agreed that an assessment of compliance with the revised twenty five Basel Core Principles should be made by end-March 2011, with the participation of two internationally-recognized bank supervisors (proposed as a new structural benchmark). There are some overlapping areas of this exercise with the Jännäri report, but the latter was principally a targeted assessment of past supervision deficiencies in the run up to the crisis. An updated BCP assessment for Iceland (the last one was in 2003) will allow review of operation of the new system, and help identify areas that require further strengthening. 


\section{E. Private Sector Debt Restructuring}

26. The authorities and staff agreed that accelerated private debt restructuring is needed to reduce the debt overhang and support growth (LOI 18). High household and corporate debt (about 130 and 370 percent of GDP in September 2008), has weighed on domestic demand. Moreover a large part of the banks' loan book will require some degree of restructuring. Targeted measures for distressed households could help limit the decline in private consumption. Corporate debt restructuring could help prevent exit of viable, albeit over-leveraged companies and eventually boost corporate investment. Successful restructuring would also restore banks' capacity to resume new lending, and could help improve the external debt outlook.

\section{The authorities have put in place a framework for household debt restructuring}

(LOI 18). The framework aims to help the 20-25 percent of the households that the CBI estimates to be in distress. Individuals have access to the Domestic Debt Advisory Services (DAS), which provides information and financial advice on available restructuring options. These include (Table 12): generalized measures which households are automatically eligible for; private voluntary workouts with their financial institutions (which have developed a menu of options for various types of borrowers); and court-supervised procedures (if other procedures proved insufficient). To date, many households with healthier balance sheets have chosen to opt out of the generalized scheme, and voluntary workouts have been slow to take root (they are expected to span the next 18 months). The new banks expect to be able to financially cope with the restructuring framework, in part because the opt-out rate is expected to rise as the economy recovers and inflation subsides, and also in light of existing provisions on their books (the HFF will have to expand its bond issuance to cover the reduction in inflows due to rescheduling, but the volumes are not projected to be large enough to crowd out budget borrowing). Staff and authorities agreed that across-the-board debt write-downs, as some had proposed, were not an option, in light of heavy and unaffordable costs (well beyond provisions on financial firms' books) and the moral hazard this would create.

\section{It was agreed that the low rate of usage to date of the household framework} called for some further refinements (LOI 18). Discussions with stakeholders suggested that key reasons for the modest progress include: public confusion and expectation of further assistance; gaps in addressing debtors in real need, and technical design deficiencies in the current framework (e.g. built in incentives for delay). With these problems in mind, it was agreed that some changes to the framework need to be passed into law by end-June (a new program structural benchmark). The changes would primarily aim at: (i) providing additional debt advisory or mediation tools for debtors to facilitate debt workouts; (ii) providing further incentives to expedite voluntary out-of-court workouts; and (iii) expanding the coverage of debt distressed individuals. The authorities stressed that after these refinements they plan not to introduce any further modifications to the framework and indeed would allow the twice-extended moratorium on foreclosures to expire with no further extensions. 
29. Out-of-court voluntary workouts remain the agreed approach for corporate debt restructuring in Iceland (LOI 18). The financial and technical capacities of the banks are estimated to be sufficient to address the restructuring, and the authorities and staff thus see no need to establish an AMC at this point. Under the framework, financial institutions have already developed out-of-court guidelines, which have been approved by the FME and are currently subject to Competition Authority Review. The guidelines aim to harmonize the initiatives among financial institutions and to expedite restructuring for firms, with an aim to have it mostly complete in 12-18 months.

\section{The guidelines for corporate workouts are designed to overcome several} impediments to voluntary debt restructuring. Restructuring can be held up by conflicts of interest among creditors (the 'hold-out' problem); asymmetric information between corporate debtors and creditors (e.g. about the value of collateral); constraints to securing new financing; and by capacity problems when it comes to handling the large number of small and medium enterprises. The authorities and staff agreed on a number of measures to help overcome these problems (Table 13). Appropriate governance in government-owned institutions was also an important objective: the public finances must be protected, but excessive managerial concern about public scrutiny could delay restructuring. This dilemma is made more acute by Iceland's small size and tight knit business community. However, rules on minimum criteria for when loans can be changed, and a committee to be established to monitor and report on the restructuring process to the parliament, should help guard against both of these extremes.

\section{The discussions also addressed direct government involvement in restructurings} (LOI 18). It was recognized that while the government did not have the resources to provide incentives and had to protect its claims, its procedures should not unnecessarily delay restructuring efforts. Existing problems included requirements to use the clogged court system in order to access partial tax exemptions for write-offs; and the short length of public receivable installment repayment agreements (other countries have offered extended plans in the wake of crises, for instance Singapore in 1997). The authorities expect to make proposals, and also indicated that they intended to review their approach to negotiated settlements with debtors who could not pay. They emphasized that this was a matter of streamlining procedures and would not fundamentally alter the government's ultimate claim.

\section{The authorities and staff agreed that amendments to the insolvency regime} would be needed to support large-scale debt restructuring (Table 14, LOI 18). A bill to do so is expected to be passed by end-June 2010. There was broad agreement that key issues include: insufficient court capacity to handle a large volume of cases over an extended period; complications due to the cross border aspect of many companies' debts; and ensuring integrity of secured creditors' rights. It was agreed that capacity constraints had to be addressed by keeping cases out of court to the extent possible and thus, the authorities have committed to assess by end-June 2010 whether the establishment of features such as 'prepackaged rehabilitation plans' would be advisable. In addition, the authorities are also 
committed to revamp the court system's capacity through an increase in the number of judges and assistant judges (by 13 percent). Finally, a commission has been set up to make proposals to reform the criminal law in order to reduce strain on the court system both on the District and Supreme courts levels.

Table. Estimates of Potential Pressures to the District Courts

\begin{tabular}{|c|c|c|c|}
\hline & \multicolumn{3}{|c|}{ percentage increase relative to $2004-071 /$} \\
\hline & \multicolumn{3}{|c|}{ Increase in workload 2/ } \\
\hline & 2010 & 2011 & 2012 \\
\hline \multicolumn{4}{|l|}{ Low-end estimates for 2010} \\
\hline \multicolumn{4}{|c|}{ A. Without considering complex criminal cases } \\
\hline & $35-40$ & $35-40$ & $30-35$ \\
\hline \multicolumn{4}{|c|}{ B. Considering complex criminal cases } \\
\hline & $50-65$ & $50-70$ & $45-60$ \\
\hline \multicolumn{4}{|l|}{ High-end estimates for 2010} \\
\hline \multicolumn{4}{|c|}{ A. Without considering complex criminal cases } \\
\hline & $45-50$ & $50-55$ & $55-60$ \\
\hline \multicolumn{4}{|c|}{ B. Considering complex criminal cases } \\
\hline & $60-80$ & $65-85$ & $70-90$ \\
\hline
\end{tabular}

\section{F. Program Modalities}

33. Key elements of program monitoring through early-2011 have now been set out:

- Extension and rephasing. Following the delay in completing the second review, the authorities have requested an extension of the arrangement to August 31, 2011. They have also requested a rephasing of undisbursed amounts: one review would be eliminated, with the disbursement spread over the last three program reviews. The extension reflects the fact that key program objectives will take longer than anticipated to realize. In particular, delays in restoring international financial market access have affected the timetable for more fully securing fiscal sustainability and establishing a fully operational financial sector.

- $\quad$ Program performance will continue to be monitored through quarterly reviews. The next review is expected to take place after July 15, based on end-May performance criteria, with subsequent reviews returning to the quarterly pattern. Quantitative performance criteria are being proposed for May and September 2010, and indicative targets are being proposed for December 2010 (LOI Table 1 and TMU). 
Iceland: Access and Phasing Under the Stand-By Arrangement, 2008-111/

\begin{tabular}{lrrll}
\hline & \multicolumn{2}{c}{ Purchases } & \\
\cline { 2 - 3 } Date Available & \multicolumn{2}{c}{ Percent of } & \\
\hline & SDR mns & quota & & Conditions include \\
\hline November 2008 & 560 & 476.2 & Board approval of arrangement \\
28 October 2009 & 105 & 89.3 & First review completion and observance of end-December 2008 PCs \\
15 December 2009 & 105 & 89.3 & Second review completion and observance of end-October 2009 PCs \\
15 July 2010 & 105 & 89.3 & Third review completion and observance of end-May 2010 PCs \\
25 November 2010 & 105 & 89.3 & Fourth review completion and observance of end-September 2010 PCs \\
25 February 2011 & 140 & 119.0 & Fifth review completion and observance of end-December 2010 PCs \\
25 May 2011 & 140 & 119.0 & Sixth review completion and observance of end-March 2011 PCs \\
15 August 2011 & 140 & 119.0 & Seventh review completion and observance of end-June 2011 PCs \\
& & & \\
Total & 1400 & 1190.5 & \\
\hline
\end{tabular}

Source: IMF staff estimates

- $\quad$ Five new structural benchmarks are proposed in support of program objectives in the fiscal and financial sectors (LOI Table 2, and LOI 10, 14, 15, 17, 18):

Amendments to the fiscal framework for local governments (to be passed into law by end 2010) will assist in the design and implementation of the fiscal adjustment, and contain future fiscal risks in this important segment of the general government.

$>$ Recapitalization of two large savings banks (by end-May 2010) will bring the initial stage of bank restructuring to completion, help to more fully establish the banking system, and set the stage for needed operational and loan restructuring.

Any recapitalization and rehabilitation measures required by the FME for nonbank financial institutions and the HFF (after a review of their plans, by endAugust 2010) will help ensure that these key components of the financial system remain solvent and sufficiently liquid to honor debt coming due over the next three years without the government absorbing private sector losses.

A Basel Core Principles assessment of the bank supervisory regime and a strategic plan to address identified weaknesses (to be completed and published by end March 2011) will ensure that the changes being implemented to the system have been effectively implemented, and that they are comprehensive enough to provide a strong regulatory framework to preserve financial stability once Iceland exits from post-crisis measures.

$>$ Amendments to the household sector debt restructuring framework (to be passed into law by end-June 2010) will facilitate faster private sector debt restructuring, and thus reduce the private debt overhang. This in turn will help to underpin the economic recovery and support improvements in debt ratios. 


\section{The financing gap, and reserve adequacy, are broadly unchanged from the time} of the first review (Table 15). Reserves are expected to peak in 2010 as exceptional financing is disbursed, followed by a temporary but sharp drop in 2011 when amortization peaks, and old bank resolution committees are expected to pay out large accumulated recovered assets. Over the medium-term, reserves are built back up, boosted by current account and capital account inflows. Reserve coverage appears more than adequate relative to projected imports, but appears inadequate relative to short-term debt coverage and relative to more sophisticated measures of the optimal level of reserves (reserves-to-GDP, at roughly 30 percent, are now below the optimal calculated level of 45 percent). ${ }^{1}$ Of course, short-term debt coverage measures should be adjusted for the planned gradual phase out of capital controls over time, with due account for possible circumvention. Making this adjustment, reserves do appear adequate, but 2011 outflows do put pressure on coverage ratios. This, and the risk of higher-than-expected circumvention, illustrates the continued need for the full amount of financing in the program.

Iceland: Reserve cover, 200944
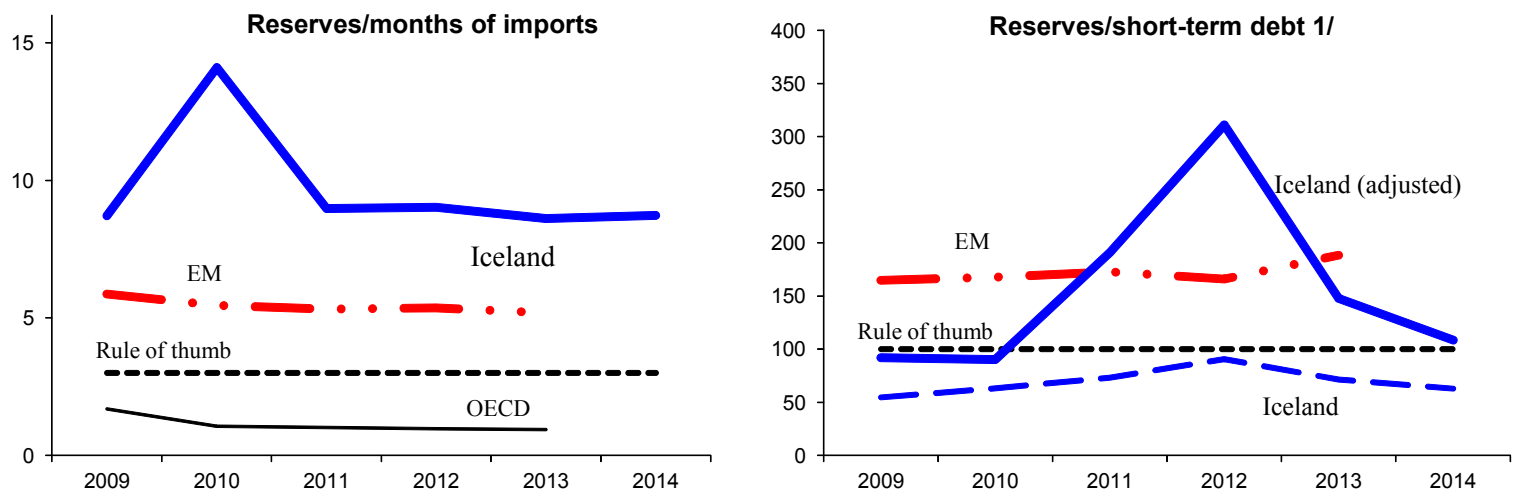

Sources: WEO, staff estimates. Emerging market (EM) and OECD data are medians.

1 / Short-term debt is on residual maturity basis. Adjusted measure for Iceland excludes short-term debt subject to capital controls, and a large multinational (with offsetting assets and liabilities)

\footnotetext{
${ }^{1}$ Jeanne and Ranciere (2006). "The Optimal Level of International Reserves for Emerging Market Countries: Formulas and Applications" IMF Working Paper 06/229.
} 
Iceland: Financing Needs, 2008-11 (in billions of US dollars)

\begin{tabular}{lcccccccc}
\hline & \multicolumn{4}{c}{ Program 1/ } & \multicolumn{5}{c}{ Current projection } \\
& 2008 & 2009 & 2010 & 2011 & 2008 & 2009 & 2010 & 2011 \\
\hline Overall balance & -18.7 & -0.3 & -2.6 & 0.1 & -18.1 & -0.4 & 0.0 & -2.8 \\
Financing & 18.7 & 0.3 & 2.6 & 0.3 & 18.7 & 0.4 & 0.0 & 2.8 \\
$\quad$ Reduction in reserves & -0.9 & -1.4 & 0.4 & 0.0 & -0.9 & -0.3 & -2.8 & 2.1 \\
Accumulation of arrears & 18.8 & -5.6 & 0.0 & 0.0 & 18.8 & 0.0 & -5.4 & 0.0 \\
Extraordinary Financing & 0.8 & 7.3 & 2.2 & 0.3 & 0.8 & 0.7 & 8.2 & 0.6 \\
$\quad$ Fund & 0.8 & 0.3 & 0.7 & 0.3 & 0.8 & 0.2 & 0.5 & 0.6 \\
$\quad$ Bilateral (earmarked / non-cash) & 0.0 & 5.6 & 0.0 & 0.0 & 0.0 & 0.0 & 5.4 & 0.0 \\
$\quad$ Other identified new financing & 0.0 & 1.4 & 1.5 & 0.0 & 0.0 & 0.5 & 2.3 & 0.0 \\
$\quad$ Residual financing gap & 0.0 & 0.0 & 0.0 & 0.0 & 0.0 & 0.0 & 0.0 & 0.0 \\
\hline
\end{tabular}

Source: Central Bank of Iceland, Fund staff estimates and calculations.

1/ 1st review under the Stand-By Arrangement, October 20, 2009 (EBS/09/159).

35. Financing assurances are in place (LOI 20). All bilateral loans have been agreed, save for an expected macro-stabilization loan from the EU, which is taking longer than expected to negotiate. To date, Iceland has received $\$ 50$ million from the Faroe Islands, and requested and received two-thirds of the first Nordic tranche, \$440 million, in December, 2009. Further Nordic financing is linked to progress in resolving the Icesave deposit insurance dispute with the U.K. and Netherlands. Delays in Nordic disbursements can be accommodated under the program: the capital control liberalization strategy is designed to automatically adjust to the balance of payments outlook. With the controls effective and a current account surplus, Iceland should have sufficient financing over the next 12 months to support the policies in place. Regarding the prospect for eventually securing this bilateral finance, the authorities have given their assurance that they remain committed to negotiating a settlement of the Icesave issue that can garner enough political support in Iceland to be fully enacted, and have been actively engaging with the opposition to this end. The Icelandic, British and Dutch authorities have made progress towards a new deal, but completing negotiations may take some time.

\section{Staff believes that the modified program puts Iceland in a position to fulfill its} obligations to the Fund in a timely manner. External debt remains on a downward trajectory. Fund credit outstanding would still peak in 2011 at 52 percent of gross reserves and then rapidly fall. Payments would peak in 2012-13 at a manageable 11 to 13 percent of reserves. As before, the pace of capital account liberalization, which is geared towards the level of reserves, provides comfort that payments can be met even if the external financing environment is somewhat weaker than envisaged. In addition, the past pattern of import compression in response to shocks, offers further comfort that shocks (e.g., from terms of trade) can be absorbed despite high debt-servicing obligations. 
Iceland: Indicators of Fund Credit 200815

(in millions of SDR)

\begin{tabular}{lrrrrrrrr}
\hline & 2008 & 2009 & 2010 & 2011 & 2012 & 2013 & 2014 & 2015 \\
\hline Existing and prospective Fund credit & & & & & & & & \\
$\quad$ Disbursements & 560 & 105 & 315 & 420 & 0 & 0 & 0 & 0 \\
Stock & 560 & 665 & 980 & 1400 & 1120 & 748 & 433 & 105 \\
Obligations & 0 & 10 & 17 & 34 & 317 & 399 & 330 & 333 \\
$\quad$ Principal (repurchases) & 0 & 0 & 0 & 0 & 280 & 372 & 315 & 328 \\
$\quad$ Charges and interest & 0 & 10 & 17 & 34 & 37 & 27 & 15 & 5 \\
Stock of existing and prospective Fund credit & & & & & & & \\
In percent of quota & 476 & 565 & 833 & 1190 & 952 & 636 & 368 & 89 \\
In percent of GDP & 5.1 & 8.7 & 11.9 & 16.1 & 12.2 & 7.8 & 4.2 & 0.9 \\
In percent of exports of G\&S & 11.6 & 16.8 & 22.4 & 31.1 & 23.4 & 14.8 & 8.1 & 1.8 \\
In percent of gross reserves & 24.3 & 31.5 & 24.3 & 53.2 & 39.3 & 25.1 & 13.5 & 3.3 \\
Obligations to the Fund from existing and prospective Fund arrangements & & & \\
In percent of quota & 0 & 8 & 15 & 29 & 269 & 339 & 281 & 283 \\
In percent of GDP & 0.0 & 0.1 & 0.2 & 0.4 & 3.5 & 4.2 & 3.2 & 3.1 \\
In percent of exports of G\&S & 0.0 & 0.2 & 0.4 & 0.8 & 6.6 & 7.9 & 6.2 & 5.9 \\
In percent of gross reserves & 0.0 & 0.5 & 0.4 & 1.3 & 11.1 & 13.3 & 10.3 & 10.9 \\
\hline
\end{tabular}

Source: IMF staff estimates and projections.

\section{There remain large risks, which the program addresses:}

- High debt brings risks of a low-growth, high-emigration trap. The large debt burden, and accompanying threat to reserves, requires significant demand-dampening measures, including fiscal tightening and capital controls. However, the slightly slower pace of fiscal adjustment in 2010, and measures to accelerate private sector debt restructuring, should help mitigate these risks.

- $\quad$ Policy mis-sequencing remains a concern. A balance must be maintained between the gradual release of capital controls, the steady adjustment of the fiscal deficit, and financial system reforms. A sequencing misstep could have significant implications for external and domestic stability. Against this, the authorities' coordinated capital control liberalization and public debt management plans, and upfront actions to strengthen the financial sector regulatory framework, will help avoid missteps.

- Uncertainty persists about the level of external private sector debt. The collapse of the banking sector led to a massive compression of Iceland's balance sheet, and the complexity of the many cross-border financing instruments is still being untangled. However, the latest data are more comprehensive in their scope, and the stress tests discussed in the debt sustainability appendix provide comfort that debt would remain on a downward path in the event of an additional negative shock.

- While the authorities remain committed to an Icesave solution to unlock bilateral program financing, it is possible that wider political barriers in Iceland prove 
insurmountable. In the event that the bilateral finance under the program is no longer available, the authorities' economic program would confront a serious challenge in late 2011, when external public debt maturities begin to rise. Coping with this would likely require a considerable re-orientation of policies, including deep fiscal cutbacks. The authorities are aware of the possible challenge and have contingency plans in place, and have committed in the letter of intent to consult with the Fund in the event of this contingency.

- $\quad$ Finally, litigation risks remain, related to the Emergency Law. A December 2009 ruling by the European Surveillance Authority dismissed complaints about the Emergency Law, although this is just the start of what will likely be a lengthy process. Successful litigation, and the resulting additional external public debt, could overwhelm the ability of the authorities to successfully adjust towards a sustainable medium-term growth path.

\section{Staff Appraisal}

38. Iceland's recession, while deep, has been less severe than expected to date. The operation of automatic fiscal stabilizers, capital controls, and the blanket deposit guarantee, have all provided support and breathing space. The more shallow recession has contributed to a slightly slower disinflation, but current account imbalances have rapidly unwound. Quarterly GDP growth is expected to resume during 2010, towards a recovery in the medium-term.

39. The key policy frameworks Iceland needs to extricate itself from the crisis are now in place. It has taken about 16 months to recapitalize the banking system and put into place fiscal consolidation, public debt management and capital control liberalization strategies, and a framework for private debt restructuring. The process has revealed bottlenecks in Iceland's small administration, but the program is now on track: targets have been met, 3 of 4 benchmarks have been observed (albeit with some delays), and for the one remaining benchmark on savings bank recapitalization, substantial progress has been achieved.

40. Implementing the agreed policy framework will require sustained political commitment. Fiscal consolidation, capital account liberalization and private debt restructuring will take time and work. A sustained effort to consult the public and build support for policies will be needed. It will be particularly important to reassure the public that while exit from the crisis will take time, the policies in place can deliver it.

\section{While a policy framework is now in place, nimble policy implementation} remains crucial. Risks remain considerable, and the recovery in particular will face headwinds, particularly from fiscal consolidation and distressed private sector balance sheets. Program fiscal and financial sector objectives need to be met to secure a durable recovery 
robust to risks, but there is scope to adjust 2010 macroeconomic policies to help secure recovery in the near-term.

42. Fiscal consolidation remains of paramount importance, but lower debt provides a little space for more gradual adjustment. The reduction in the targeted primary adjustment from 5 $\frac{1 / 2}{2}$ to $4 \frac{1}{4}$ percent of GDP in 2010 can provide some support to the economy while maintaining an improved outlook for public debt. Staff welcomes the authorities' efforts in the budget to preserve the key features of the social safety net. Work should commence early in the next budget cycle on the adjustment measures needed for 2011-12.

43. Fiscal consolidation needs to be supported by appropriate public debt management and an appropriate fiscal federal framework. Iceland needs to make an early and gradual effort to resume borrowing in international markets, and an effort to smooth the maturity profile of domestic debt, following the plan laid out in the recently approved medium-term public debt management strategy. Meanwhile, greater fiscal coordination, monitoring and control will support adjustment efforts, and planned reforms to the fiscal federal framework should be enacted in time for the next fiscal year.

\section{Preserving currency stability remains the best monetary policy framework for} delivering program inflation and growth goals. Tighter administration of capital controls has supported the currency of late, and continued vigilance against circumvention is needed, including a willingness to tighten restrictions if necessary. In light of uncertainties about the timing of new external borrowing the emphasis in implementing policy in the near-term should be on accumulating reserves. The next capital account liberalization step will need to await a stronger balance of payments outlook.

45. Financial system restructuring is now reaching an important milestone, but difficult work still lies ahead. Staff welcomes the recapitalization of Landsbankinn and progress made in the recapitalization of smaller savings banks. The recap process has proven more complex than expected, but delays have helped protect the government against absorbing losses, and have helped ensure fair and equitable treatment of creditors (in line with applicable law). Attention should now shift to the remaining unrestructured savings banks, where steps to finalize recapitalization are overdue. The completion of this stage of financial sector restructuring should lay a foundation for revived lending, but to fully realize this potential, efforts will need to be directed to operational restructuring of banks, and reinforcing the non-bank financial sector.

46. Financial restructuring efforts should be matched by a strengthening of the framework for regulation and supervision. The staff welcomes draft legislation to this end, and once this is passed the FME should rapidly implement the changes. This will deal with the failings of the past, and planning should begin for a full assessment of the system against Basel Core Principles, with a view to identifying any lingering issues to be addressed. 


\section{Private sector debt restructuring is a priority, and will help offset}

macroeconomic headwinds. Staff has been concerned that while the authorities are converging on a framework, the piecemeal approach to-date has fueled public expectations about generous - but unaffordable - measures in the future. Some adjustments should be implemented in the near-term to fill gaps and address design problems in the existing framework. The right approach remains to emphasize targeted, voluntary, and fiscallyaffordable measures, and it will be important to temper expectations by communicating that further measures will not be forthcoming. The insolvency regime also needs to be refined to support debt restructurings in the corporate sector, and the focus should be on increasing the capacity of the court system to process requests.

48. Realizing bilateral external financing remains crucial to program success. Staff welcomes the authorities' continued commitment to unlock this financing, and to this end to continue with best faith efforts to reach an agreement with the U.K. and the Netherlands regarding Icesave deposits.

49. Risks are still large, but the program is capable of countering them. Risks to internal and external stability could emanate from the possible impact of high debt levels on growth, policy mis-sequencing, and litigation. However, efforts to free up policy space to counter the depressing impacts of the debt overhang; careful coordination of fiscal, financial sector and capital control liberalization plans; and timely and determined policy implementation, will help to limit these risks.

50. Implementation of the authorities' IMF-supported program in 2010 continues to represent the best opportunity for Iceland to extricate itself from post-crisis challenges. Staff supports the authorities' request for completion of the second review under the StandBy Arrangement, as well as the extension and rephasing of the arrangement and the establishment of new performance criteria. 
Figure 1. Iceland: Recent Economic Developments
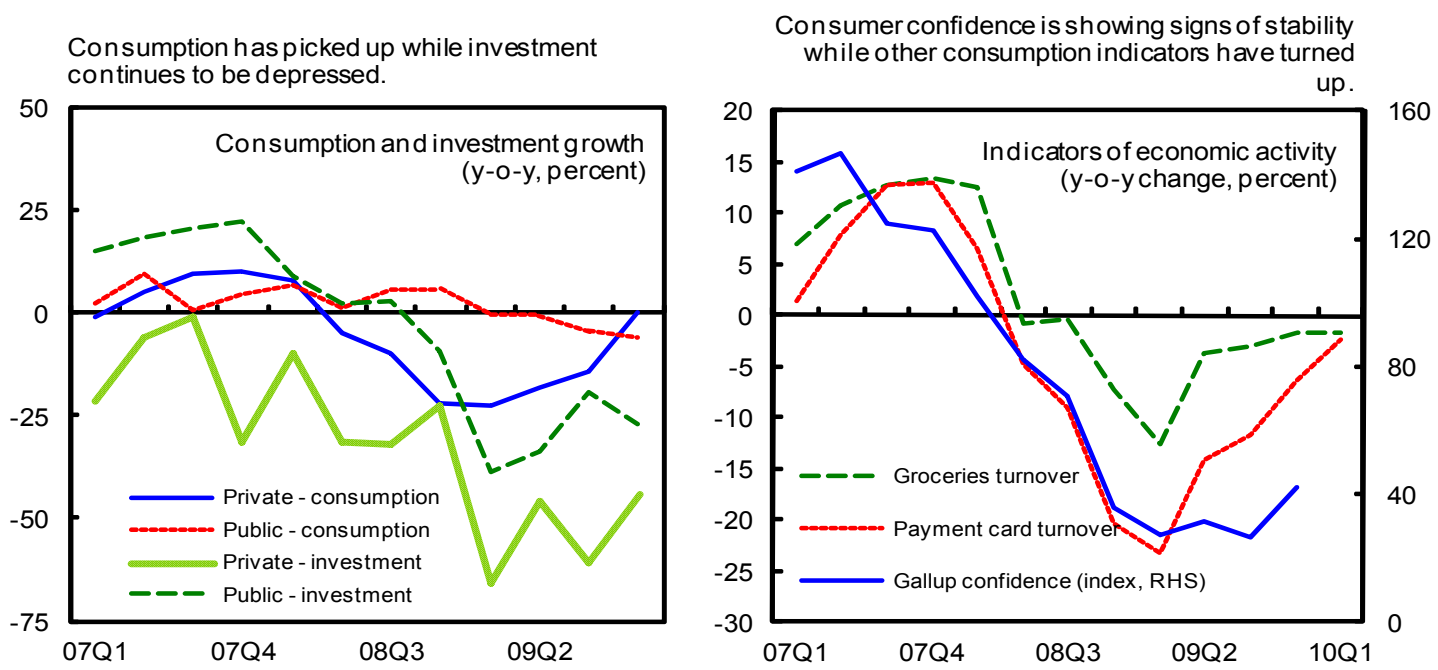

Export growth has resumed while import growth has picked up from a low base...

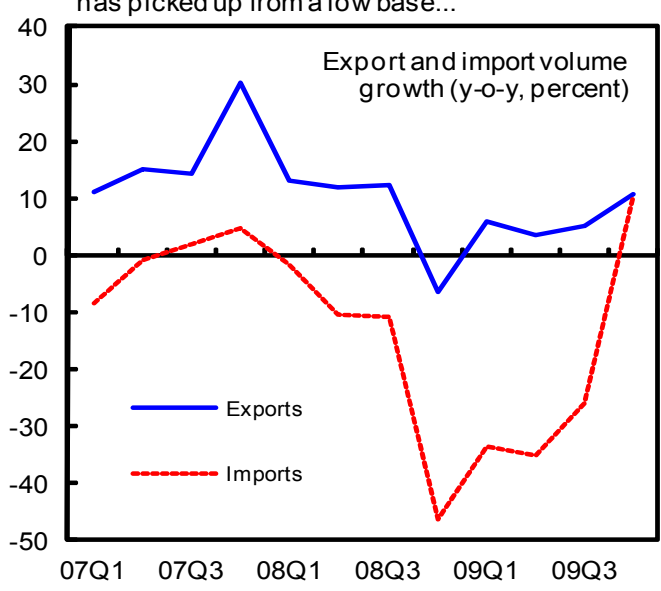

improving the trade balance.

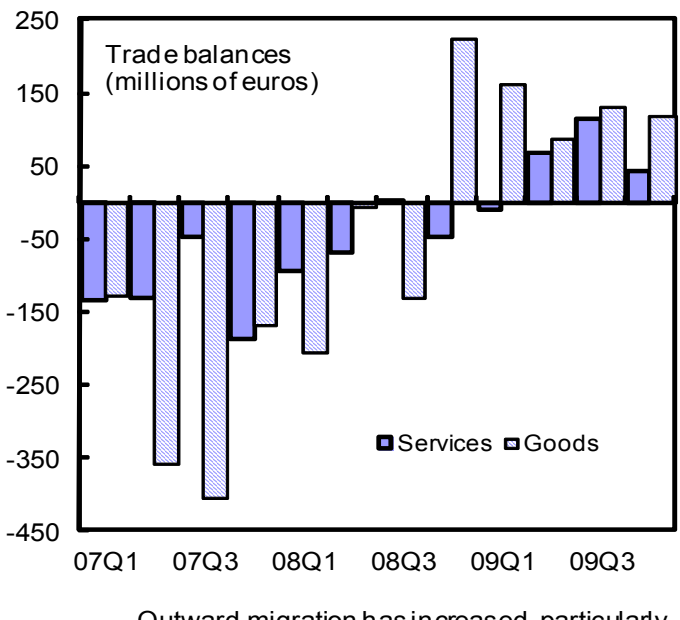

The unemployment rate ap pears to have stabilized, albeit after a sharp increase.
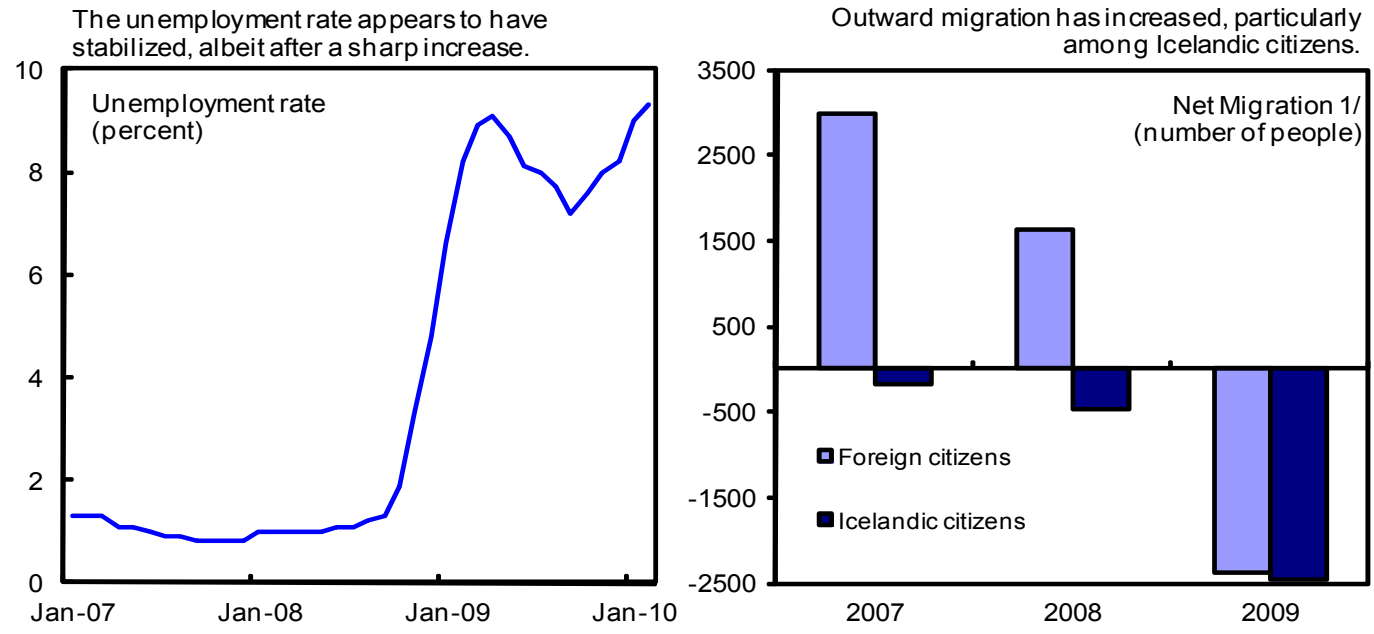

So urces:Iceland Statistics; Bloomberg; and IMF.

1/ Cumulative mon thly data January through September for 2009. 
Figure 2. Iceland: Price Developments

Disinflation continues to be gradual...

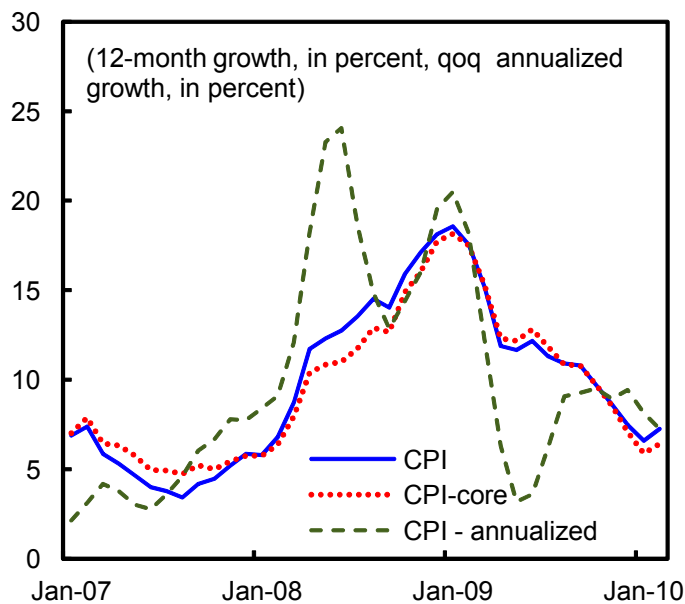

Survey indicators of expected inflation and breakeven inflation have stayed stable.

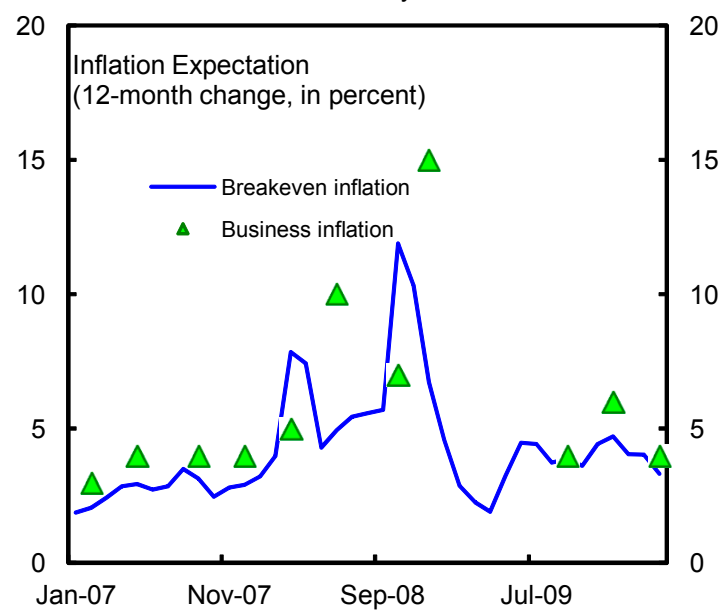

as pass-through from exchange rate persists.

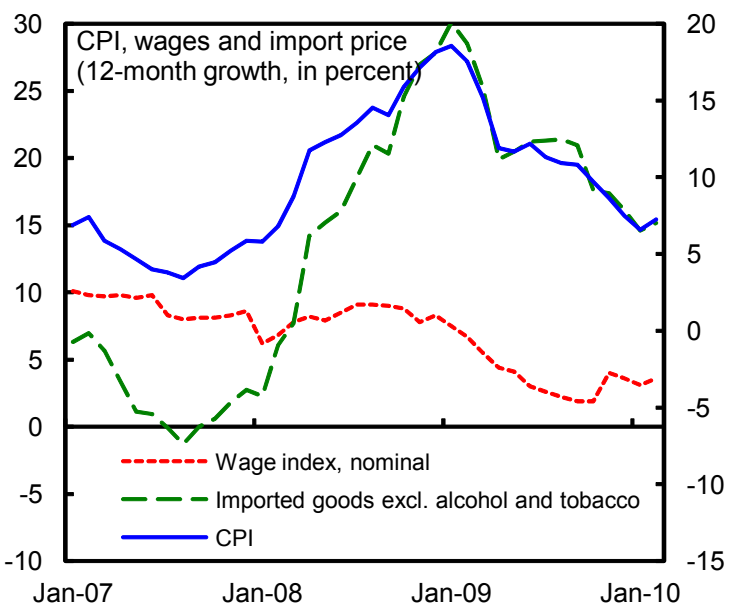

House prices are showing signs of stability after a year of decline.

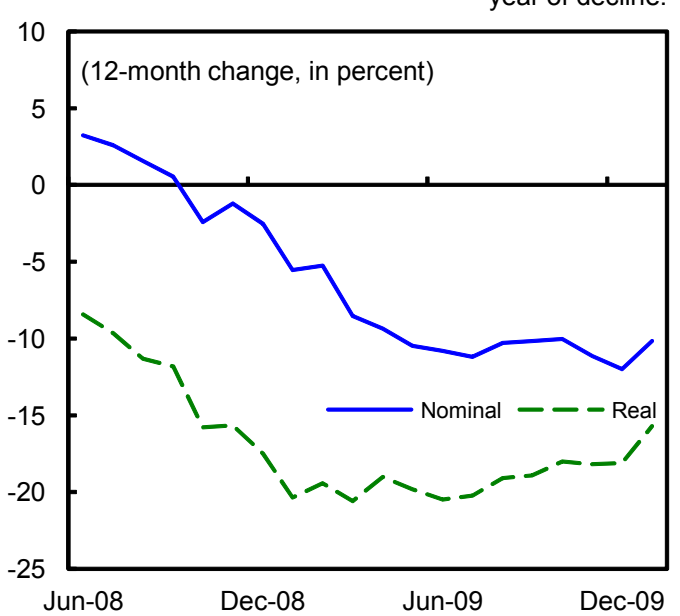

Sources: Central Bank of Iceland and IMF International Financial Statistics. 
Figure 3. Iceland: Financial Market Developments
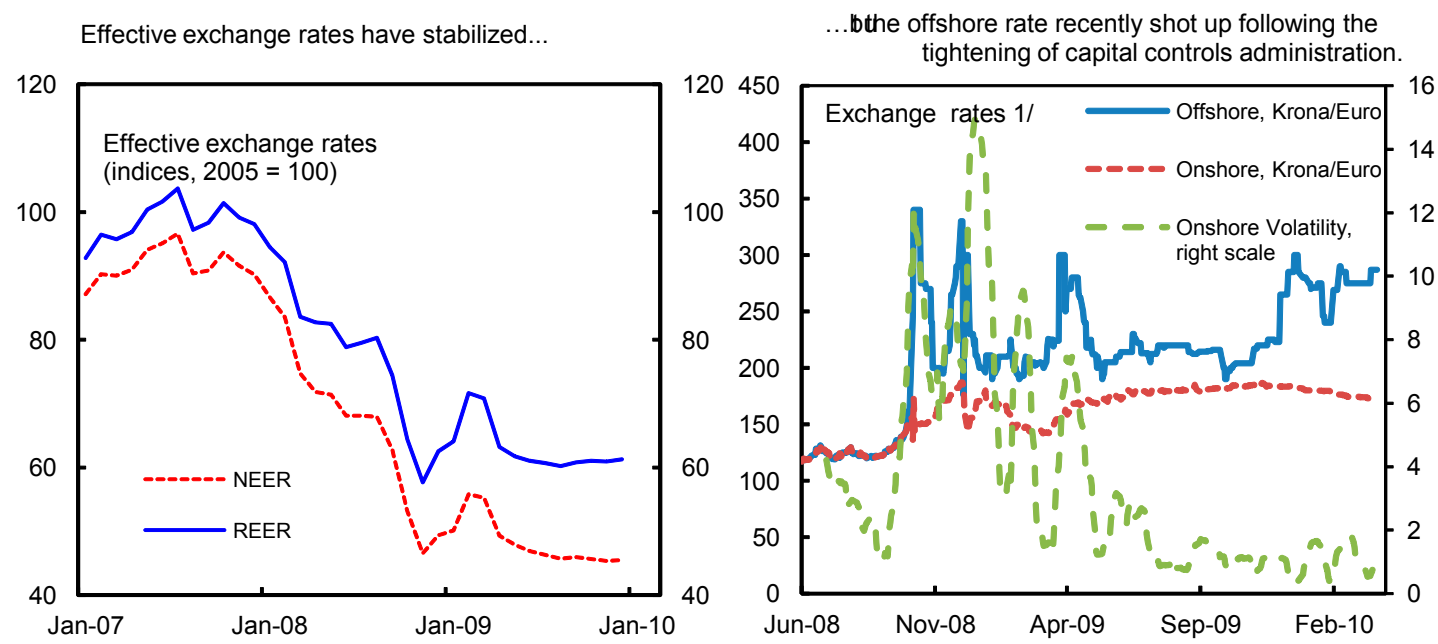

The policy interest rate corridor has been narrowed.

And the $\mathrm{CBI}$ is intervening less in the domestic forex
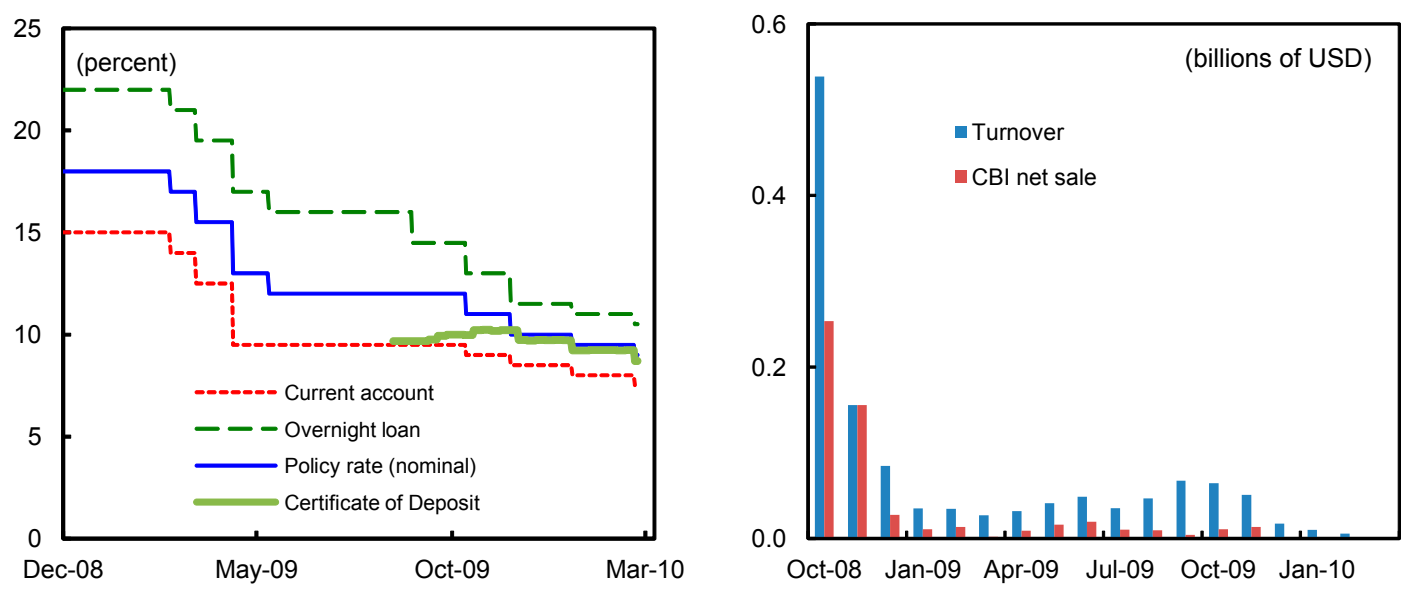

Yields on T-notes have stabilized...

...while sovereign spreads have spiked following Icesave-related uncertainty.
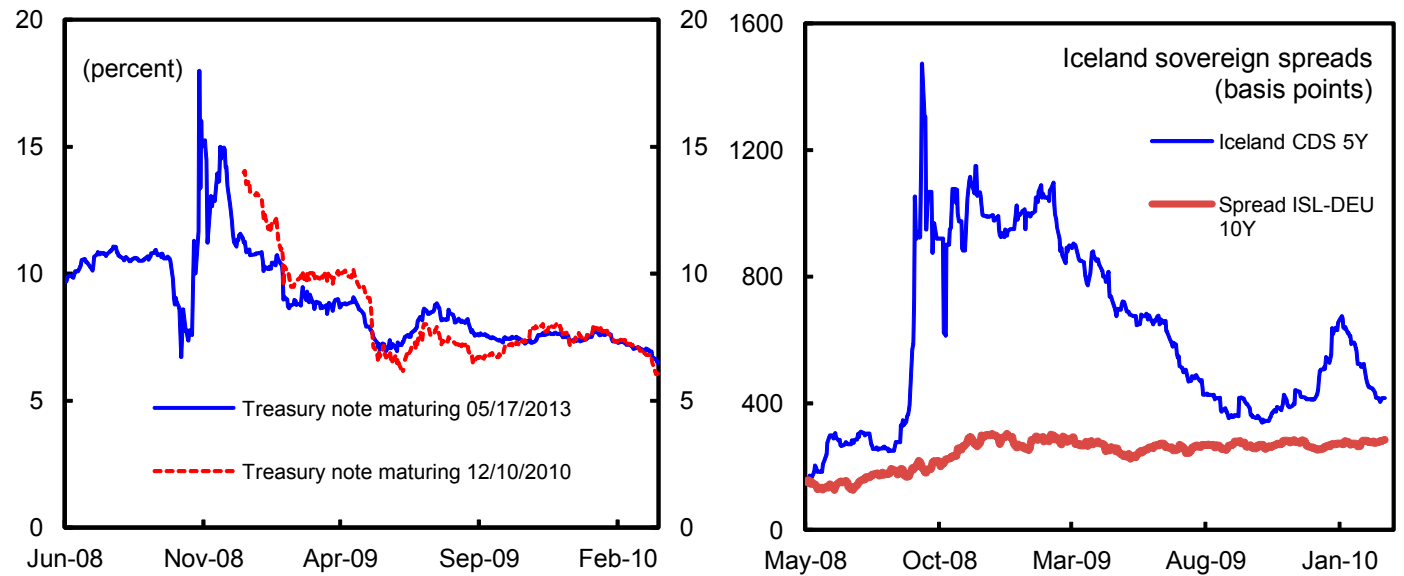

Source: Central Bank of Iceland, Bloomberg, and DataStream.

$1 /$ Onshore volatility calculated as a 1-month moving standard deviation. 
Figure 4. Iceland: Household and Corporate Sector Conditions 1/

About half of corporate loans and one-third of small retail loans are nonperforming.

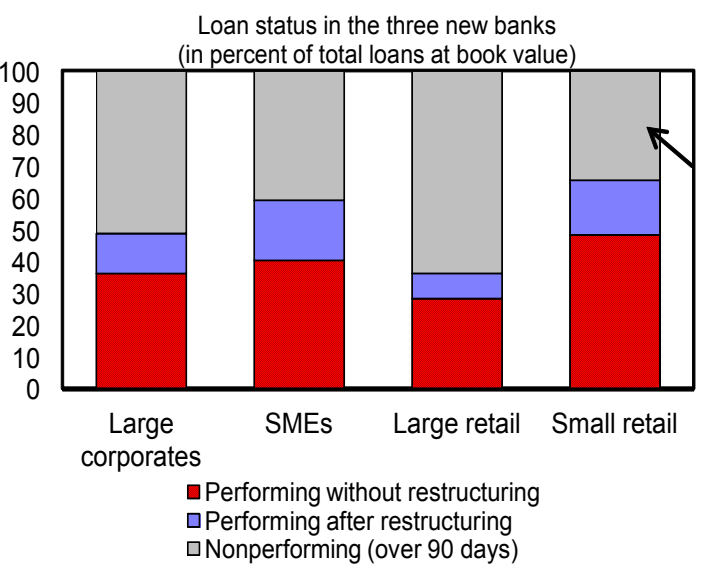

Most of the nonperforming small retail loans are ISKdenominated....

ISK loans: status in the three new banks

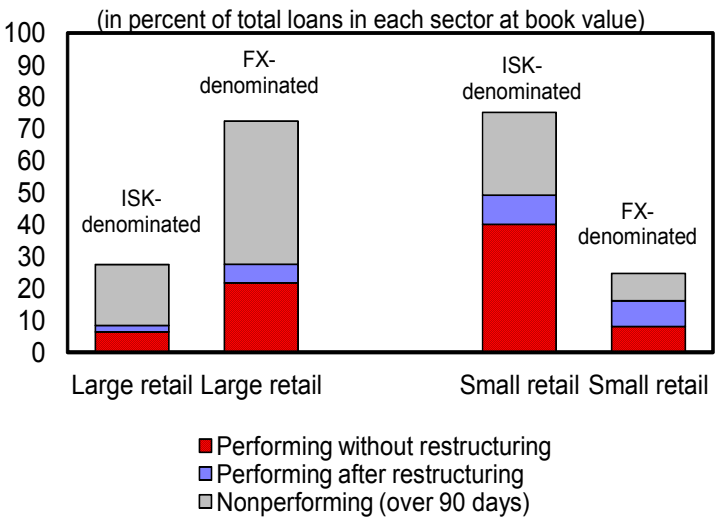

A small share of households have large fx exposures.

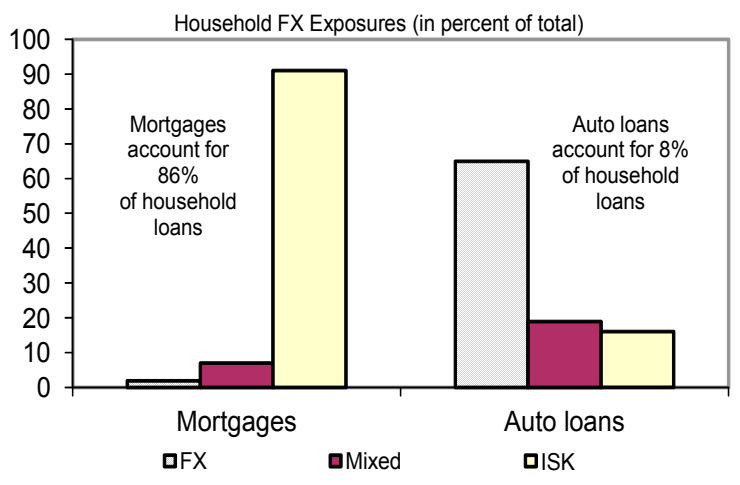

... but the number of nonperforming individuals on small retail loans are relatively small.

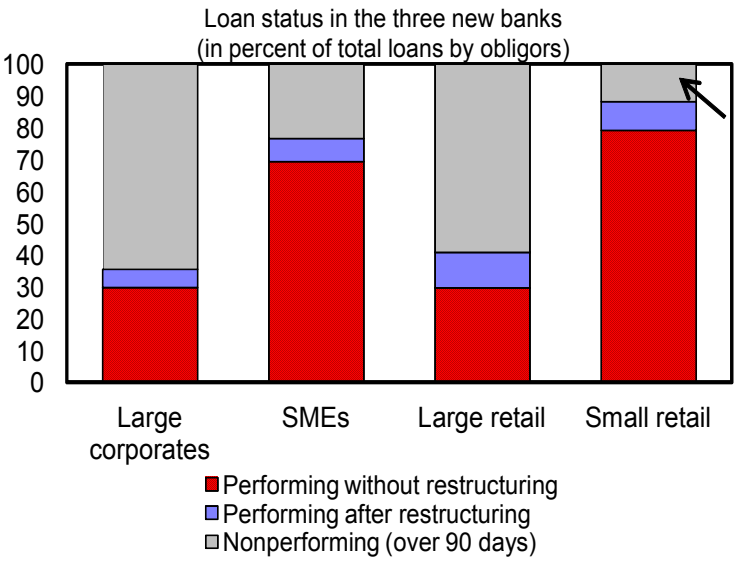

but a large majority of nonperforming loans in large corporates and SMEs are fx-denominated.

FX loans: status in the three new banks (in percent of total loans in each sector at book value)

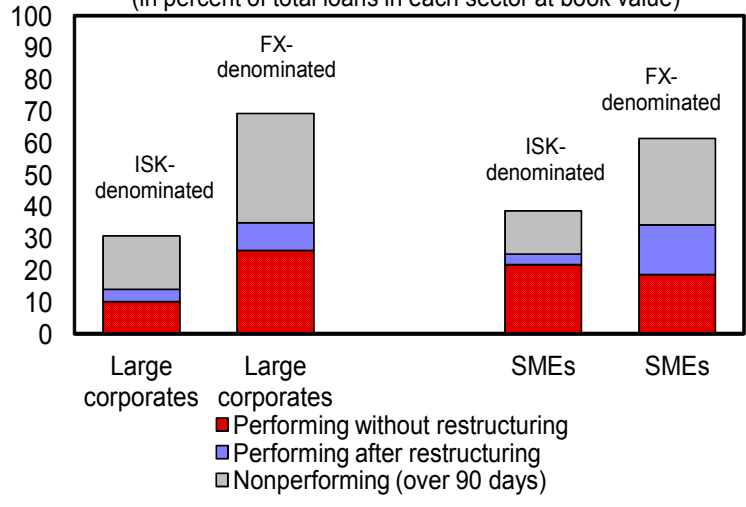

And corporations with large fx exposures are holding companies and fisheries.

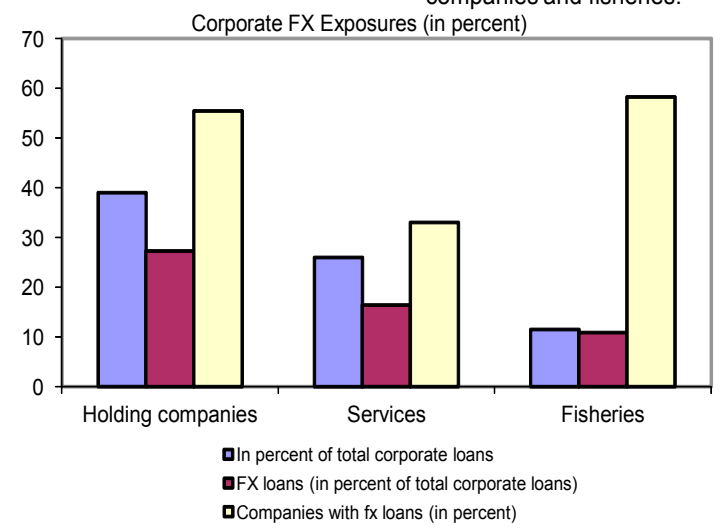

Source: FME, central bank, and commercial banks.

1/ Estimates as of Jan-2010 for the top and middle panels. Excludes the HFF. Large retail refers to loans with claims over ISK 100 million. An individual could have multiple obligations in one bank or multiple banks and be counted as different obligors. 
Figure 5. Iceland: Macroeconomic Outlook Compared to the $1^{\text {st }}$ Review
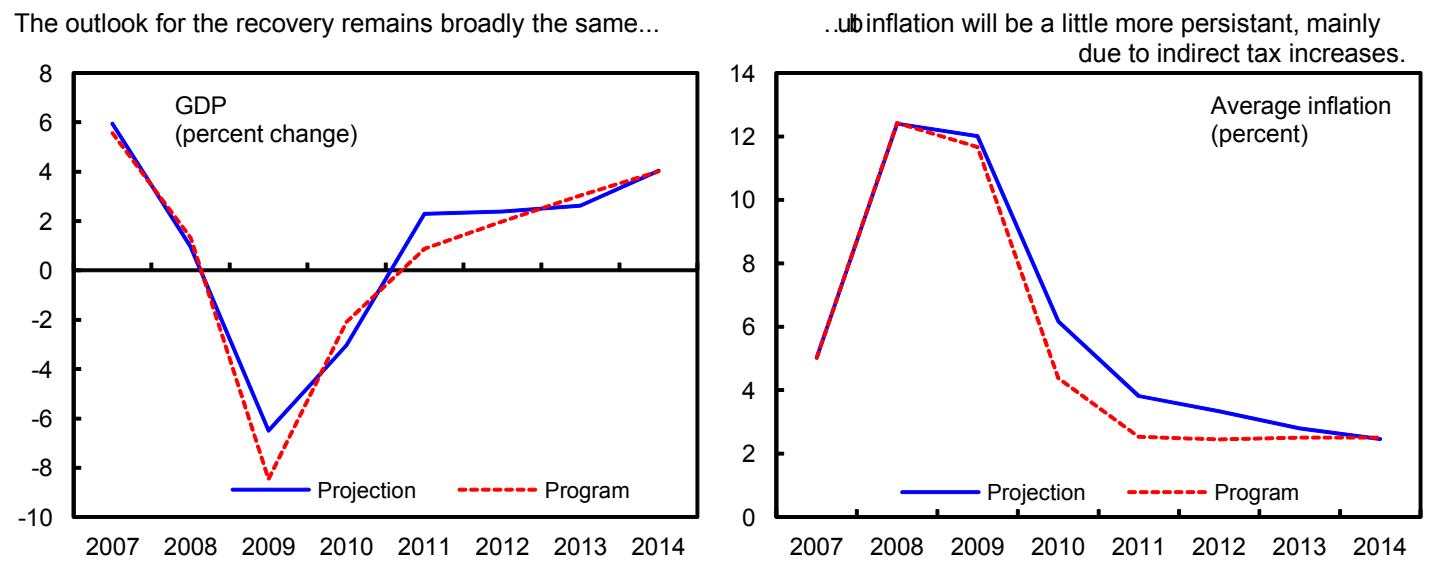

Private consumption is expected to be stronger, reflecting buoyancy this year...
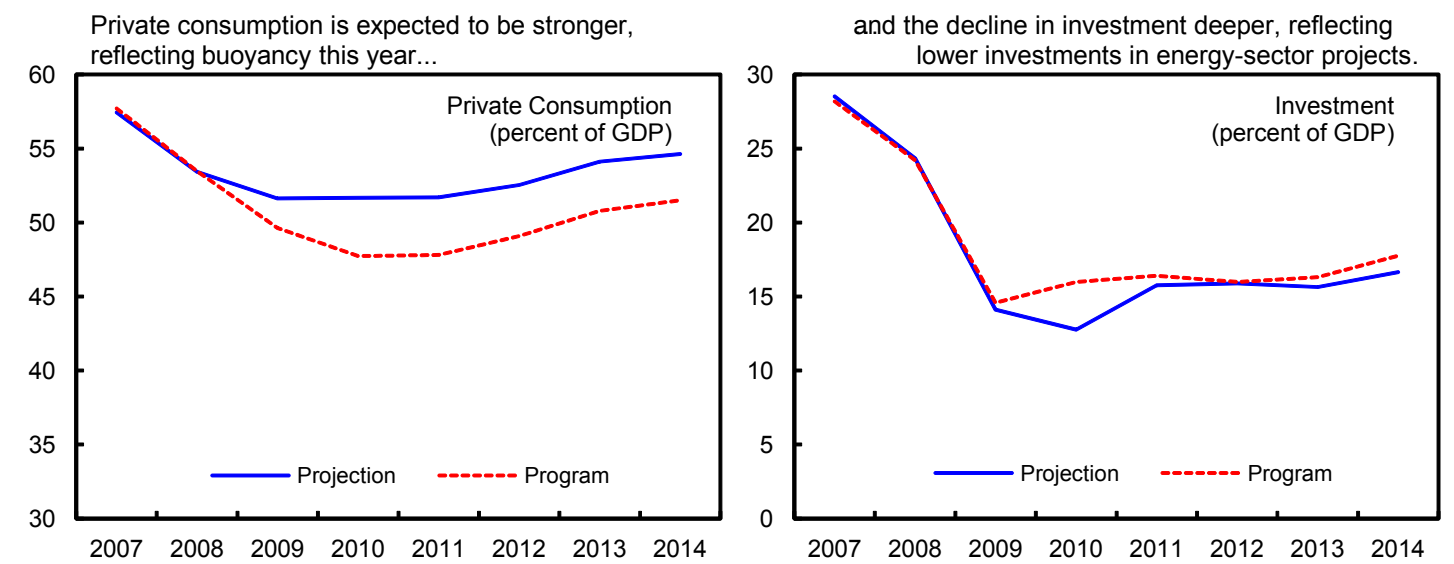

The expected trade balance improvement is broadly
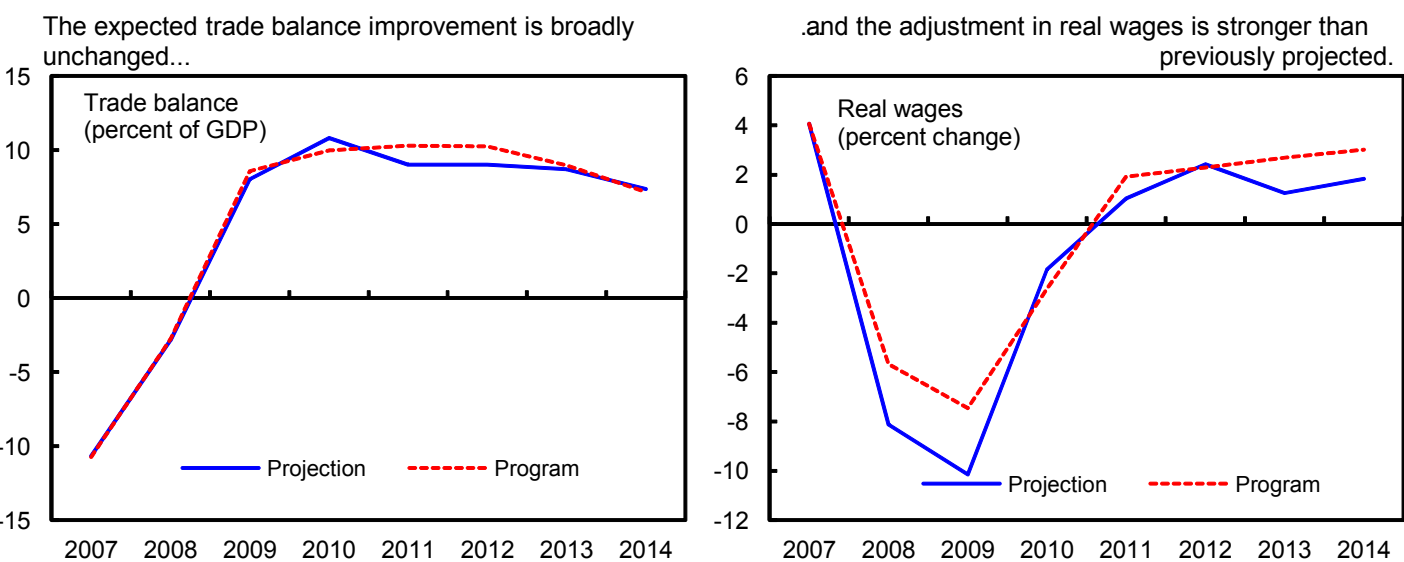

Sources: Program documents and staff projections 
Figure 6. Iceland: GDP Growth and Export Performance
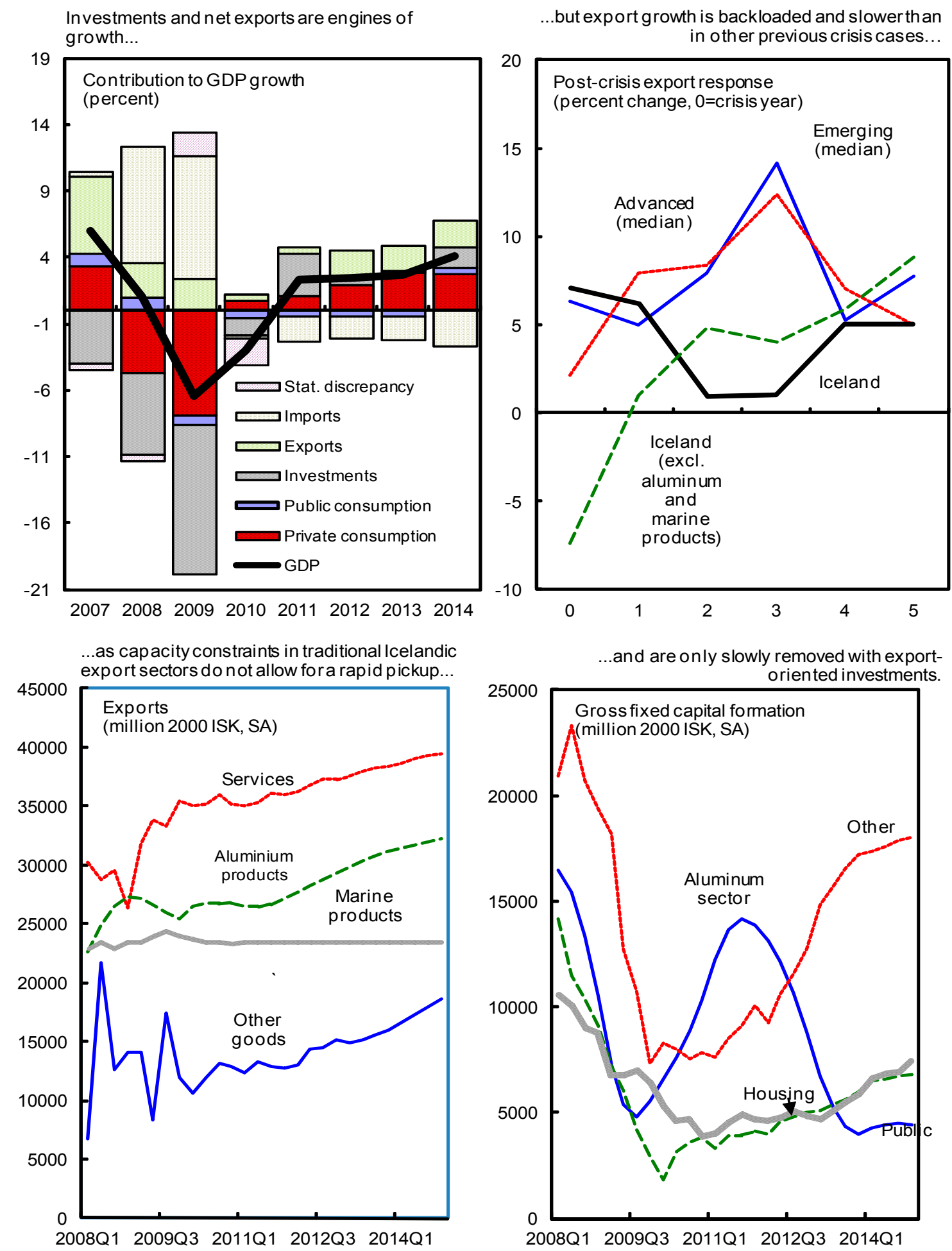

Source: Statistics Iceland and staff projections. 
Figure 7. Iceland: Structure of Fiscal Adjustment and International Comparisons

Primary adjustment in 2010 would remain well in line with fiscal consolidations experienced in other Nordic countries..

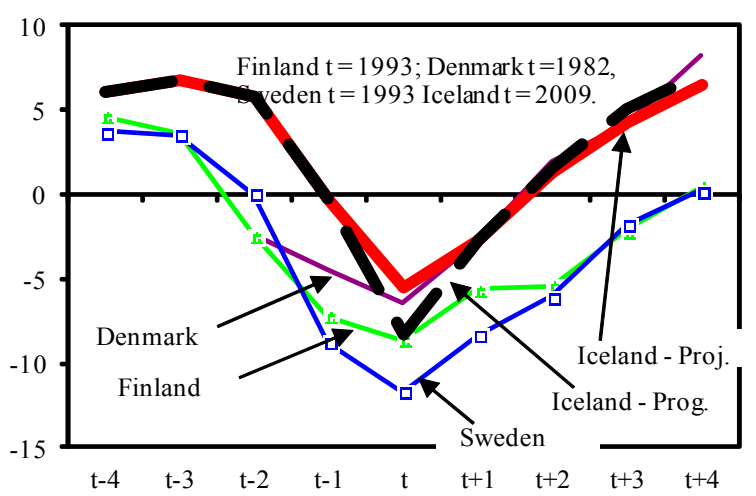

The authorities are aiming to keep their tax system in line with other Nordic tax systems.

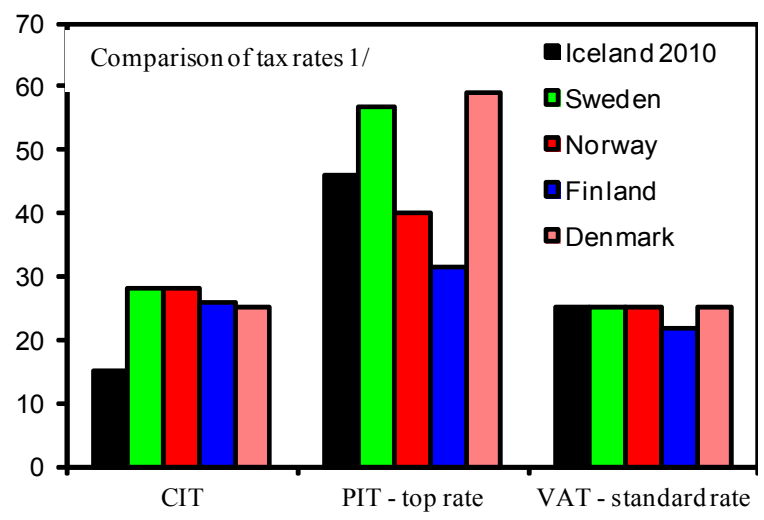

Fast real spending growth of the past is being reversed...

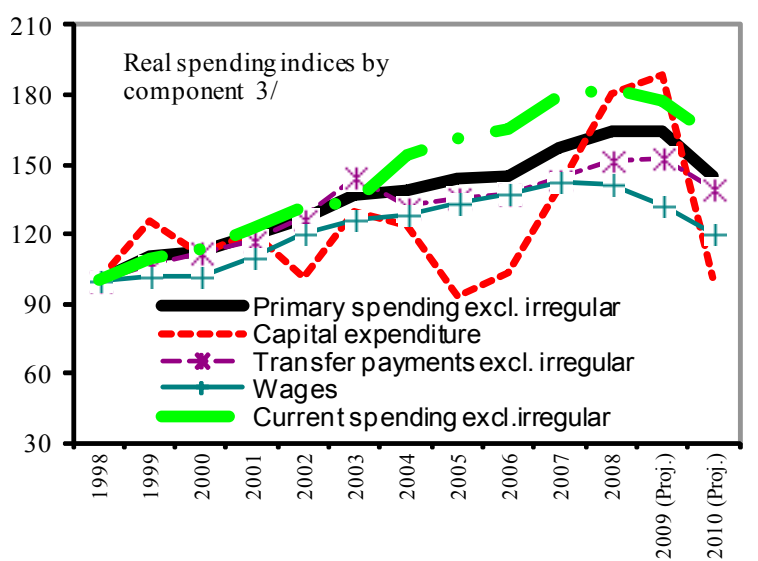

...while leaving the debt-to-GDP ratio below the earlier program projections.

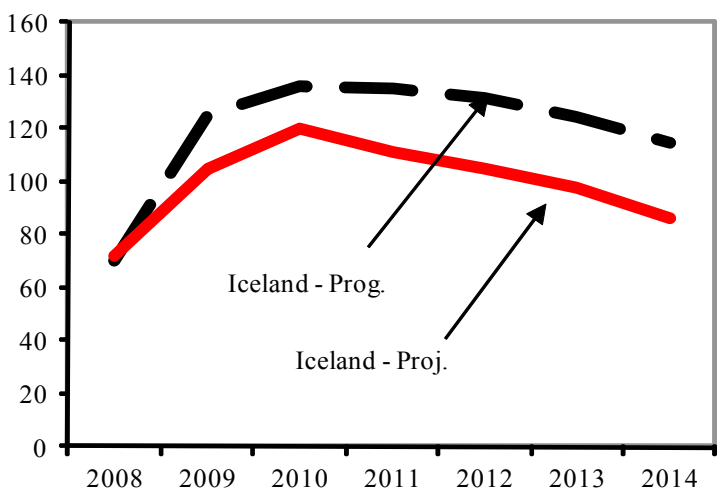

The newly introduced th ree-bracket PIT is expected to increase progressivity.

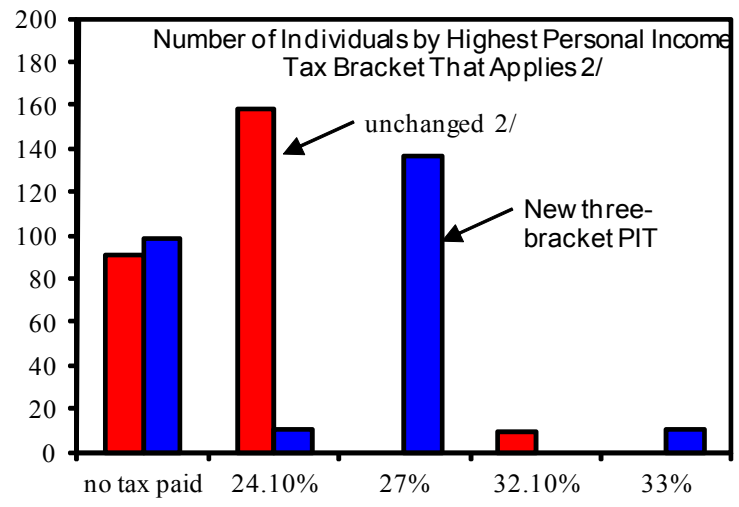

...while real spending on ed ucation, health, housing, and welfare is being comparatively protected.

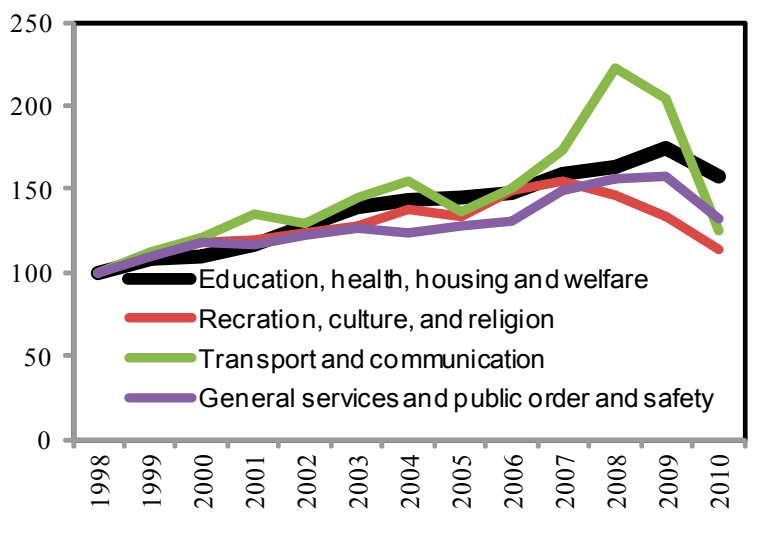

Source: WEO, Icelandic authorities, and Fund staff estimates

1/ For PIT and CIT: Based on information in 2007: Sweden, Norway; Based on information in 2008: Finland, Denmark, U.K., For VAT: Based on end2008.

2/ Personal income tax levied by the central government only. In addition, a uniform 13.1 percent tax is levied on personal income by local authorities. The comparison refers to what the 2009 PIT system would have generated without allowing the automatic indexation of the tax free credit.

$3 /$ Irregular items are excluded. These include unemployment benefits, interest cost rebates, pension liabilities, capital gains tax paid by the Treasury, 
Figure 8. Iceland: Public Debt Management Plan

Domestic maturities will become less concentrated ...

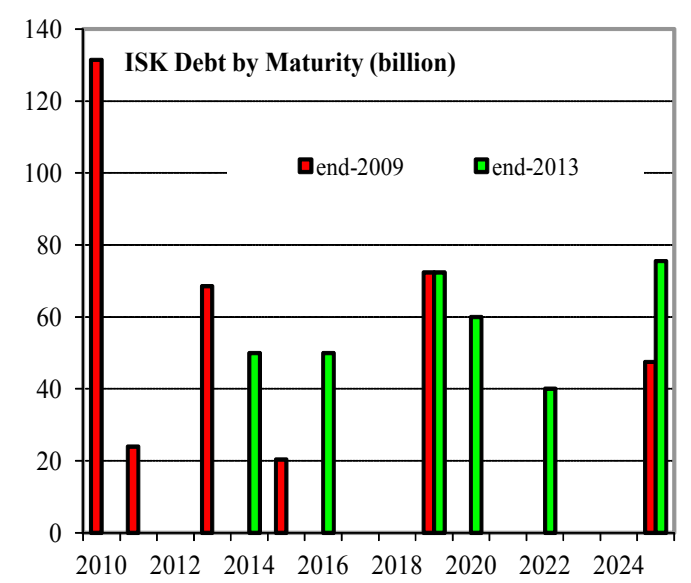

A cash buffer will cover up to 6 months of maturing securities...

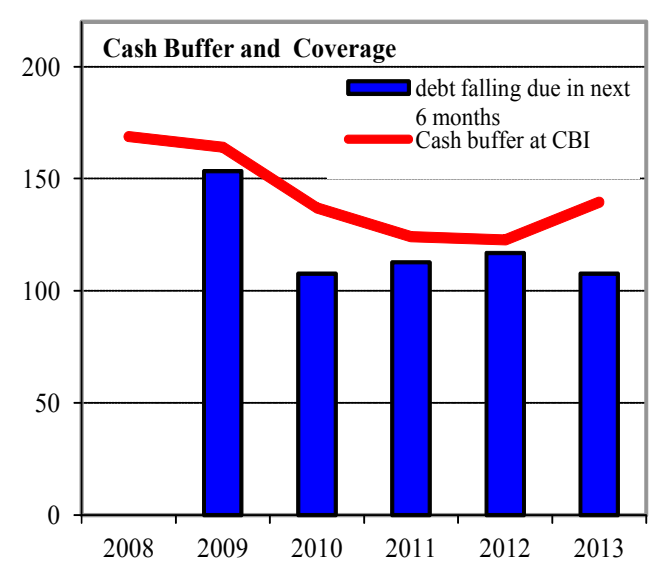

.And the average maturity will increase to up

to 4 years.

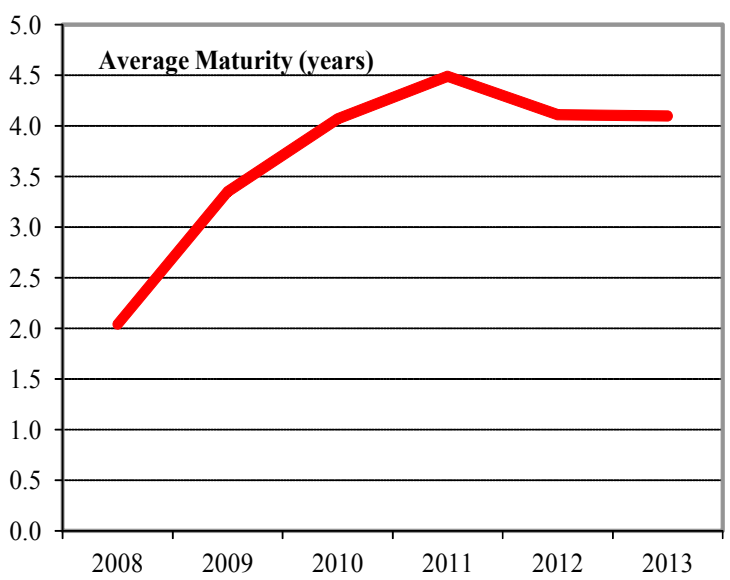

...while foreign exchange reserves adequately cover government short term debt.

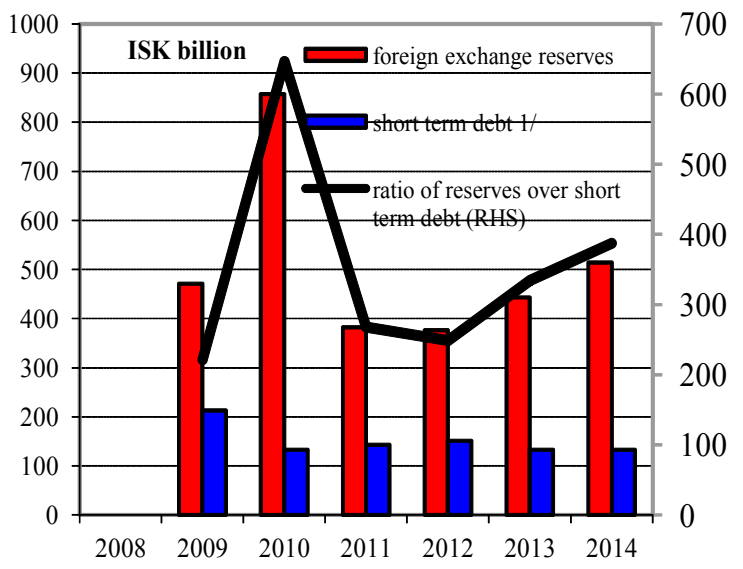

Source: Icelandic authorities and staff projections. 1/ Residual basis. 
Figure 9. Iceland: Local Government Finance
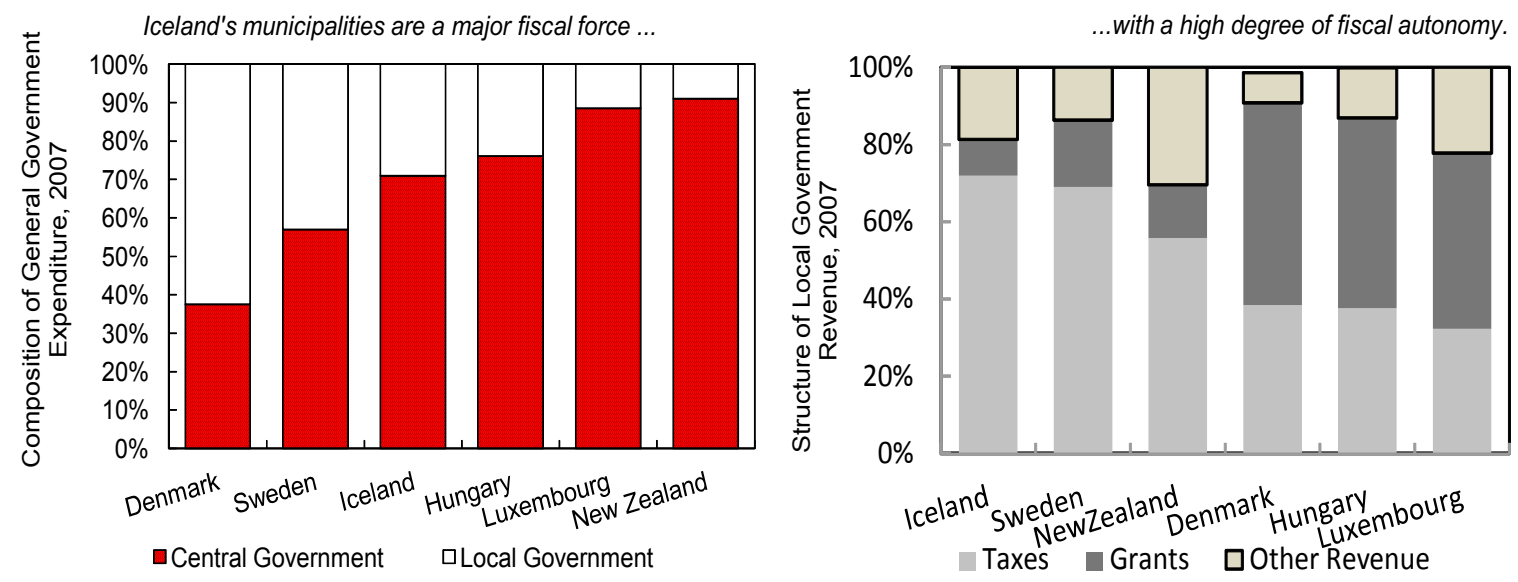

Iceland is one of the increasingly few OECD countries with

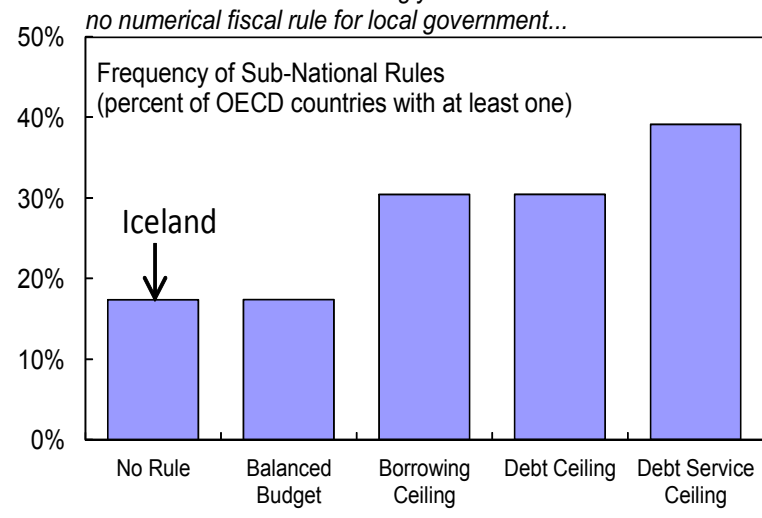

...and no restrictions on municipalities' access to credit

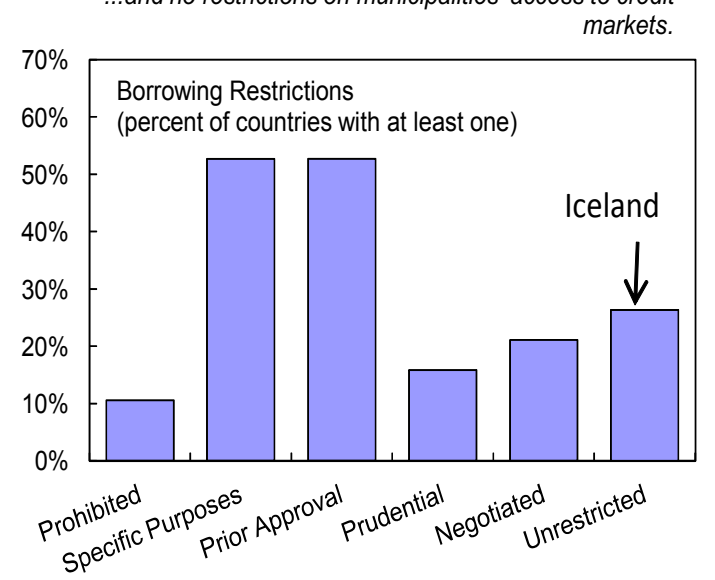

Monitoring mechanisms are under-developed...
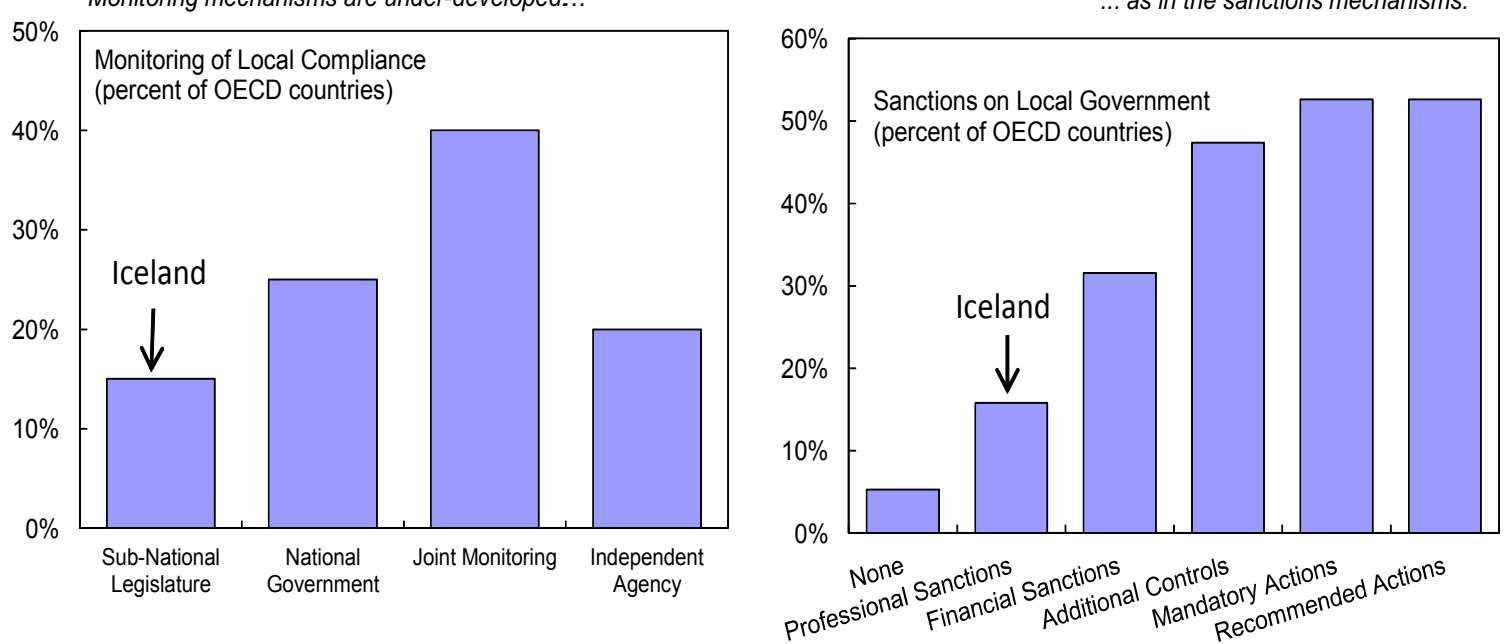

Source: OECD and Fund staff calculations. 
Table 1. Iceland: Selected Economic Indicators 200540

\begin{tabular}{|c|c|c|c|c|c|c|c|}
\hline & \multirow[t]{2}{*}{2005} & \multirow[t]{2}{*}{2006} & \multirow[t]{2}{*}{2007} & \multirow[t]{2}{*}{2008} & \multicolumn{2}{|c|}{2009} & \multirow[t]{2}{*}{2010} \\
\hline & & & & & Prog. & Est. & \\
\hline \multicolumn{8}{|c|}{ (Percentage change unless otherwise noted) } \\
\hline \multicolumn{8}{|l|}{ National Accounts (constant prices) } \\
\hline Gross domestic product & 7.5 & 4.6 & 6.0 & 1.0 & -8.5 & -6.5 & -3.0 \\
\hline Total domestic demand & 15.8 & 9.0 & 0.2 & -8.9 & -20.7 & -20.0 & -1.3 \\
\hline Private consumption & 12.7 & 3.6 & 5.6 & -7.9 & -17.0 & -14.6 & 1.4 \\
\hline Public consumption & 3.5 & 4.0 & 4.1 & 4.6 & -0.1 & -3.0 & -2.5 \\
\hline Gross fixed investment & 35.7 & 22.4 & -11.1 & -21.0 & -50.6 & -49.9 & -10.0 \\
\hline Export of goods and services & 7.5 & -4.6 & 17.7 & 7.1 & -1.5 & 6.2 & 1.0 \\
\hline Imports of goods and services & 29.3 & 10.4 & -0.7 & -18.2 & -30.5 & -24.0 & 0.8 \\
\hline Output gap $1 /$ & 3.2 & 2.2 & 3.7 & 1.8 & -3.2 & -2.9 & -3.5 \\
\hline \multicolumn{8}{|l|}{ Selected Indicators } \\
\hline Nominal GDP (bln ISK) & $1,026.7$ & $1,168.6$ & $1,308.5$ & $1,477.6$ & $1,472.5$ & $1,500.2$ & $1,620.5$ \\
\hline Central bank gross reserves (bln ISK) & 67.3 & 167.8 & 162.8 & 429.3 & 617.5 & 485.3 & 854.4 \\
\hline Unemployment rate $2 /$ & 2.1 & 1.3 & 1.0 & 1.6 & 8.6 & 8.0 & 9.7 \\
\hline Real disposable income per capita & 6.6 & -2.0 & 5.4 & $\ldots$ & & $\ldots$ & \\
\hline Consumer price index & 4.0 & 6.8 & 5.0 & 12.4 & 11.7 & 12.0 & 6.2 \\
\hline Nominal wage index & 6.5 & 9.1 & 9.3 & 3.3 & 3.3 & 0.6 & 4.2 \\
\hline Nominal effective exchange rate $3 /$ & 10.4 & -10.7 & 2.7 & -40.4 & -34.2 & -34.7 & $\ldots$ \\
\hline Real effective exchange rate (CPI) $3 /$ & 13.3 & -7.1 & 5.1 & -20.7 & -18.0 & -18.8 & $\ldots$ \\
\hline Terms of trade & 1.0 & 3.5 & 0.1 & -9.3 & -8.5 & -7.0 & 6.0 \\
\hline \multicolumn{8}{|l|}{ Money and Credit } \\
\hline Base Money & 23.1 & 25.4 & 182.0 & -31.5 & 24.4 & 1.3 & $\ldots$ \\
\hline Deposit money bank credit (end-period) & 76.0 & 44.4 & 56.6 & -28.3 & $\ldots$ & $\ldots$ & $\ldots$ \\
\hline of which to residents (end-period) & 54.7 & 33.6 & 28.3 & & & & $\ldots$ \\
\hline Broad money (end-period) & 23.2 & 19.6 & 56.4 & 36.3 & 8.3 & -4.4 & $\ldots$ \\
\hline $\mathrm{CBI}$ policy rate (period average) 4 / & 10.5 & 14.1 & 13.8 & 15.4 & $\ldots$ & 13.7 & $\ldots$ \\
\hline \multicolumn{8}{|l|}{ Public Finance (in percent of GDP) } \\
\hline \multicolumn{8}{|l|}{ General government $5 /$} \\
\hline Revenue & 47.1 & 48.0 & 47.7 & 44.2 & 38.4 & 39.5 & 39.2 \\
\hline Expenditure & 42.2 & 41.6 & 42.3 & 44.8 & 52.7 & 51.9 & 48.6 \\
\hline Balance & 4.9 & 6.3 & 5.4 & -0.5 & -14.4 & -12.4 & -9.4 \\
\hline Primary balance & 6.1 & 6.7 & 5.7 & -0.3 & -8.3 & -6.9 & -2.7 \\
\hline \multicolumn{8}{|l|}{ Balance of Payments (in percent of GDP) } \\
\hline Current account balance & -16.1 & -25.6 & -16.3 & -15.8 & -3.5 & 3.8 & 5.4 \\
\hline Trade balance & -12.2 & -17.5 & -10.1 & -2.3 & 8.6 & 8.4 & 10.8 \\
\hline Financial and capital account & 13.9 & 44.0 & -9.0 & -76.7 & 6.8 & -11.6 & -5.2 \\
\hline Net errors and omissions & 2.6 & -11.1 & 25.8 & -20.5 & -5.3 & 10.4 & 0.0 \\
\hline Gross external debt $6 /$ & 284.5 & 433.5 & 605.9 & 564.7 & 306.9 & 295.9 & 299.0 \\
\hline Central bank reserves (US\$ billion) & 1.1 & 2.3 & 2.6 & 3.6 & 4.9 & 3.9 & 6.7 \\
\hline
\end{tabular}

Sources: Statistics Iceland; Central Bank of Iceland; Ministry of Finance; and staff estimates.

$1 /$ Staff estimates. Actual minus potential output, in percent of potential output.

2/ In percent of labor force.

3/ A positive (negative) sign indicates an appreciation (depreciation).

4/ Data prior to 2007 refers to annual rate of return. 2007 and on, refers to nominal interest rate.

5/ National accounts basis.

6/ Including face value of old banks debt before 2009. Related interest transactions are not included from Q4 2008 on. 
Table 2. Iceland: Money and Banking

(In billion of Krona, unless otherwise noted)

\begin{tabular}{|c|c|c|c|c|c|c|}
\hline & $\begin{array}{l}\text { Dec-08 } \\
\text { Est. }\end{array}$ & $\begin{array}{l}\text { Dec-09 } \\
\text { Est. 1/ }\end{array}$ & $\begin{array}{l}\text { Mar-10 } \\
\text { Proj. }\end{array}$ & $\begin{array}{l}\text { Jun-10 } \\
\text { Proj. }\end{array}$ & $\begin{array}{l}\text { Sep-10 } \\
\text { Proj. }\end{array}$ & $\begin{array}{l}\text { Dec-10 } \\
\text { Proj. }\end{array}$ \\
\hline \multicolumn{7}{|l|}{ Central Bank } \\
\hline $\begin{array}{l}\text { Net foreign assets } 2 / \\
\text { Assets } \\
\text { Liabilities }\end{array}$ & $\begin{array}{r}-96 \\
429 \\
526\end{array}$ & $\begin{array}{r}-177 \\
485 \\
662\end{array}$ & $\begin{array}{r}-196 \\
466 \\
662\end{array}$ & $\begin{array}{r}-159 \\
610 \\
768\end{array}$ & $\begin{array}{r}-131 \\
759 \\
890\end{array}$ & $\begin{array}{r}-165 \\
855 \\
1,020\end{array}$ \\
\hline Net domestic assets & 211 & 293 & 315 & 280 & 255 & 291 \\
\hline Net claims on the public sector & 39 & -52 & -13 & -48 & -72 & -37 \\
\hline Net claims excluding recap bond & -231 & -218 & -178 & -213 & -237 & -202 \\
\hline Recapitalization bond & 270 & 165 & 165 & 165 & 165 & 165 \\
\hline Net claims on banks $3 /$ & 282 & -16 & -34 & -34 & -34 & -34 \\
\hline Others, net & -110 & 361 & 361 & 361 & 361 & 361 \\
\hline Base Money 4/ & 115 & 117 & 119 & 121 & 124 & 126 \\
\hline Currency issued & 24 & 29 & 29 & 30 & 31 & 31 \\
\hline DMB deposits at the central bank & 91 & 88 & 89 & 91 & 93 & 95 \\
\hline \multicolumn{7}{|l|}{ Banking System } \\
\hline Net foreign assets & -295 & -190 & -190 & -190 & -190 & -190 \\
\hline Net domestic assets & 2,022 & 1,820 & 1,828 & 1,836 & 1,844 & 1,853 \\
\hline Net claims on the central bank & -282 & 16 & 34 & 34 & 34 & 34 \\
\hline Credit to private sector & 2,501 & 1,777 & 1,777 & 1,777 & 1,786 & 1,795 \\
\hline Credit to government & $\ldots$ & 35 & 50 & 50 & 50 & 50 \\
\hline Other items, net & -197 & -9 & -33 & -25 & -26 & -27 \\
\hline Domestic deposits & 1,726 & 1,630 & 1,638 & 1,646 & 1,655 & 1,663 \\
\hline Local currency & 1,549 & 1,450 & 1,458 & 1,465 & 1,472 & 1,480 \\
\hline Foreign currency & 178 & 180 & 181 & 181 & 182 & 183 \\
\hline \multicolumn{7}{|l|}{ Consolidated Financial System } \\
\hline Net foreign assets & -391 & -367 & -386 & -349 & -321 & -355 \\
\hline Net domestic assets & 2,061 & 1,963 & 2,012 & 2,011 & 2,023 & 2,079 \\
\hline Net claims on the public sector $5 /$ & 39 & -17 & 37 & 2 & -22 & 13 \\
\hline Net credit to private sector & 2,501 & 1,777 & 1,777 & 1,777 & 1,786 & 1,795 \\
\hline Other, net & -479 & 202 & 197 & 232 & 259 & 270 \\
\hline Broad Money (M3) & 1,670 & 1,596 & 1,626 & 1,662 & 1,702 & 1,724 \\
\hline \multicolumn{7}{|l|}{ Memorandum items: } \\
\hline Base money (y-o-y percentage change) & -31.5 & 1.3 & -10.9 & -16.7 & -22.7 & 8.0 \\
\hline Broad money (y-o-y percentage change) & 36.3 & -4.4 & -1.5 & -4.0 & -0.2 & 8.0 \\
\hline Credit to private sector (y-o-y percentage change) & -28.3 & -28.9 & -21.7 & -19.9 & 0.5 & 1.0 \\
\hline Money velocity (GDP/base money) & 12.8 & 12.9 & 12.9 & 12.9 & 12.9 & 12.9 \\
\hline Broad money velocity (GDP/M3) & 0.9 & 0.9 & 0.9 & 0.9 & 0.9 & 0.9 \\
\hline Multiplier (M3 / base money) & 14.5 & 13.7 & 13.7 & 13.7 & 13.7 & 13.7 \\
\hline
\end{tabular}

Sources: Central Bank of Iceland; and Fund staff estimates

1/ Although the balance sheets of the new banks have been finalized, the CBI has not received full monetary data reports.

Therefore the items under the banking system and consolidated financial system remain estimates for all periods after October 2008.

2/ NFA is defined by the TMU. In particular, foreign liabilities include $\mathrm{fx}$ deposits of DMBs and government.

3/ Net claims on banks is the difference between CBI's lending to banks and banks' holding of certificates of deposits.

4/ Base money includes currency in circulation and DMBs deposits at the central bank in krona.

5/ Net claims on the public sector of the consolidated system include only net claims of the central bank up to January 2009.

Starting Feb 2009, the data also include oustanding government bonds held by the banks. 
Table 3. Iceland: Status of the Financial Sector 1/

\begin{tabular}{|c|c|c|c|c|c|c|c|}
\hline & \multicolumn{4}{|c|}{ Total assets } & \multirow{3}{*}{$\begin{array}{l}\text { Capital } \\
\text { adequacy } \\
\text { ratio (in } \\
\text { percent) 3/ }\end{array}$} & \multirow{3}{*}{$\begin{array}{l}\text { Leverage } \\
\text { ratio (in } \\
\text { percent) } 4 /\end{array}$} & \multirow{3}{*}{ Status } \\
\hline & \multicolumn{2}{|c|}{ end-Dec 2008} & \multicolumn{2}{|c|}{ end-Sep 2009 2/ } & & & \\
\hline & ISK billion & $\begin{array}{l}\text { in percent } \\
\text { of GDP }\end{array}$ & ISK billion & $\begin{array}{l}\text { in percent } \\
\text { of GDP }\end{array}$ & & & \\
\hline A. Commercial banks $1 /$ & 2,355 & 159 & 2,591 & 173 & 12.8 & 11.9 & \\
\hline Landsbankinn 2/ & 1,002 & 68 & 1,050 & 70 & $\ldots$ & 13.6 & Recapitalized \\
\hline Arion (New Kaupthing) 2/ & 641 & 43 & 705 & 47 & $\ldots$ & 11.6 & Recapitalized \\
\hline Islandsbanki & 658 & 45 & 779 & 52 & $\ldots$ & .2 & Recapitalized \\
\hline MP bank & 53 & 4 & 57 & 4 & $\ldots$ & 9.4 & \\
\hline B. Saving banks & 890 & 60 & 409 & 27 & $\ldots$ & & \\
\hline Icebank & 202 & 14 & $\ldots$ & $\ldots$ & $\ldots$ & Interven & $\begin{array}{l}\text { ed in March 2009. Now in moratorium. } \\
\text { Intervened in April } 2009 \text {. Deposits transferred to Arion with }\end{array}$ \\
\hline SPRON & 204 & 14 & $\cdots$ & $\cdots$ & $\ldots$ & $\ldots$ & $\begin{array}{l}\text { a collateralized bond to cover the deposits. Now in } \\
\text { moratorium. }\end{array}$ \\
\hline SparisjóðMtýasślu (SPM) & 43 & 3 & $\ldots$ & $\ldots$ & $\ldots$ & & Merged into Arion (New Kaupthing) \\
\hline BYR sparisjour & 253 & 17 & 232 & 15 & $\cdots$ & $\cdots$ & $\begin{array}{l}\text { Negotiations between creditors and shareholders on } \\
\text { capitalization has been completed. Final capitalization } \\
\text { options are under consideration by creditors and expected } \\
\text { to be completed by end-May } 2010 \text {. }\end{array}$ \\
\hline Sparisjóðkreflavkur & 98 & 7 & 98 & 7 & $\cdots$ & $\cdots$ & $\begin{array}{l}\text { Negotiations between creditors and shareholders on } \\
\text { capitalization has been completed. Final capitalization } \\
\text { options are under consideration by creditors and expected } \\
\text { to be completed by end-May } 2010 \text {. }\end{array}$ \\
\hline Other saving banks & 89 & 6 & 79 & 5 & $\cdots$ & $\cdots$ & $\begin{array}{l}\text { Negotiations between creditors and shareholders on } \\
\text { capitalization has been completed. Final capitalization } \\
\text { options are under consideration by creditors and expected } \\
\text { to be completed by end-May } 2010 \text {. }\end{array}$ \\
\hline C. Housing Finance Fund (HFF) & 727 & 49 & 767 & 51 & 4.2 & 1.8 & \\
\hline D. Other credit undertakings & 527 & 36 & 308 & 21 & $\ldots$ & $\ldots$ & \\
\hline
\end{tabular}

Sources: Preliminary data from $\mathrm{CBI}$ and FME, and staff calculations.

1/ Numbers for new banks are tentative and available from the FME, adjusted for the sub-ordinated instruments provided by the government under private capitalization.

2/ As of end-June 2009 for saving banks, HFF, and other credit undertakings.

3/ As of September 2009. Includes tier 1 and tier 2 capital for the new banks. New banks are given time to incorporate and compute the market risks in the

fx-denominated loans given to unhedged borrowers. The ratios represent the full computation of capital requirements.

4/ As of September 2009 for Landsbankinn and Arion and as of June 2009 for the rest. 
Table 4. Iceland: Projected External Debt Stock (gross), end-2009 (in billions of U.S. Dollars)

\begin{tabular}{|c|c|c|c|c|}
\hline & $\frac{\text { SBA Approval 1/ }}{\text { Proj. }}$ & $\frac{\text { 1st Rev. }}{\text { Proj. }}$ & $\frac{\text { 2nd Rev. }}{\text { Proj. }}$ & $\frac{\text { Explanatory Notes }}{\text { (since 1st Review) }}$ \\
\hline Total External Debt & 21.4 & 36.4 & 35.8 & \\
\hline General government (excluding crisis-related borrowing) & 2.4 & 4.7 & 5.0 & \\
\hline Central government (forex) & 2.4 & 2.5 & 2.5 & \\
\hline Central government (ISK-denominated) & 0.0 & 1.8 & 2.0 & \\
\hline Other public & 0.0 & 0.4 & 0.5 & \\
\hline General government (crisis-related borrowing) & 5.8 & 4.2 & 1.7 & \\
\hline Bilateral support & 3.0 & 1.4 & 0.5 & Disbursements postponed \\
\hline IMF & 1.4 & 1.3 & 1.2 & Disbursements postponed \\
\hline Central bank swaps/repos & 1.4 & 1.5 & 0.0 & Paid down in 4Q09 \\
\hline Deposit Insurance Fund -- Icesave obligation 2/ & 6.1 & 5.8 & 5.4 & Exchange rate movement \\
\hline $\mathrm{o} / \mathrm{w}$ amortization from asset recovery & -2.1 & 0.0 & 0.0 & \\
\hline Private Sector & 7.1 & 21.6 & 23.7 & \\
\hline Financial Sector & 1.2 & 5.2 & 3.8 & \\
\hline Other banks & 0.0 & 0.8 & 0.3 & $\begin{array}{l}\text { Lower projected asset recovery for } \\
\text { external creditors }\end{array}$ \\
\hline Nonbank financial & 0.0 & 0.9 & 0.9 & \\
\hline Nonresident deposits in banks $3 /$ & 0.0 & 2.1 & 1.7 & Downward revision \\
\hline HFF & 1.2 & 1.2 & 0.8 & Downward revision \\
\hline Other & 0 & 0.1 & 0.1 & \\
\hline Non-Financial Sector & 6.0 & 16.4 & 19.9 & \\
\hline Old Bank assets recovered from domestic sources & 0.0 & 0.0 & 2.7 & $\begin{array}{l}\text { Previously assumed to be covered } \\
\text { from external assets }\end{array}$ \\
\hline Nonfinancial corp & 0.2 & 1.3 & 1.4 & \\
\hline FDI stock & 2.0 & 10.3 & 11.4 & \\
\hline Public Enterprises & 3.8 & 3.8 & 4.2 & \\
\hline Other & 0.0 & 1.0 & 0.2 & \\
\hline \multicolumn{5}{|l|}{ Memorandum items } \\
\hline Public sector debt 14 & 13.2 & 13.9 & 11.7 & \\
\hline w/o crisis-related borrowing & 7.4 & 9.7 & 10.0 & \\
\hline Change in debt (excluding crisis-related borrowing) & $\ldots$ & 16.6 & 1.9 & \\
\hline
\end{tabular}

Sources: Central Bank of Iceland and staff estimates.

1/ Change between SBA approval and 1st review includes upward revision due to initial overestimation of ISK-denominated debt and other factors 2/ Amounts covered by deposit insurance initially estimated at USD8.2bn (subsequently revised down).

3/ Non resident deposits previously held by overseas subsisidary of Landsbanki

4/ General government plus HFF plus public enterprises. Excludes present value of estimated net Icesave obligation 
Table 5. Iceland: Medium-Term Projections, 200814

(Percentage change, unless otherwise indicated)

\begin{tabular}{|c|c|c|c|c|c|c|c|c|}
\hline & \multirow{2}{*}{$\begin{array}{c}2008 \\
\text { Est. }\end{array}$} & \multicolumn{2}{|c|}{2009} & \multirow{2}{*}{$\begin{array}{l}2010 \\
\text { Proj. }\end{array}$} & \multirow{2}{*}{$\begin{array}{l}2011 \\
\text { Proj. } \\
\end{array}$} & \multirow{2}{*}{$\begin{array}{l}2012 \\
\text { Proj. } \\
\end{array}$} & \multirow{2}{*}{$\begin{array}{l}2013 \\
\text { Proj. }\end{array}$} & \multirow{2}{*}{$\begin{array}{l}2014 \\
\text { Proj. }\end{array}$} \\
\hline & & Prog. & Est. & & & & & \\
\hline \multicolumn{9}{|c|}{ (Percentage change) } \\
\hline \multicolumn{9}{|l|}{ Real economy } \\
\hline Real GDP & 1.0 & -8.5 & -6.5 & -3.0 & 2.3 & 2.4 & 2.6 & 4.0 \\
\hline Real domestic demand & -8.9 & -20.7 & -20.0 & -1.3 & 4.3 & 2.2 & 2.9 & 5.4 \\
\hline Private consumption & -7.9 & -17.0 & -14.6 & 1.4 & 2.1 & 3.7 & 5.5 & 5.0 \\
\hline Public consumption & 4.6 & -0.1 & -3.0 & -2.5 & -2.0 & -2.0 & -2.0 & 2.5 \\
\hline Gross fixed investment & -21.0 & -50.6 & -49.9 & -10.0 & 27.9 & 3.1 & 0.9 & 11.3 \\
\hline Net exports $1 /$ & 11.3 & 11.2 & 11.7 & 0.2 & -1.5 & 0.4 & 0.0 & -0.7 \\
\hline Exports of goods and services & 7.1 & -1.5 & 6.2 & 1.0 & 1.0 & 4.6 & 4.1 & 4.3 \\
\hline Imports of goods and services & -18.2 & -30.5 & -24.0 & 0.8 & 5.9 & 4.9 & 5.3 & 7.7 \\
\hline Output gap 2/ & 1.8 & -3.2 & -2.9 & -3.5 & -2.1 & -1.7 & -0.9 & 0.0 \\
\hline Unemployment rate $3 /$ & 1.6 & 8.6 & 8.0 & 9.7 & 8.6 & 6.4 & 4.4 & 3.0 \\
\hline Real wages & -8.1 & -7.5 & -10.1 & -1.8 & 1.0 & 2.4 & 1.3 & 1.8 \\
\hline CPI inflation & 12.4 & 11.7 & 12.0 & 6.2 & 3.8 & 3.3 & 2.8 & 2.5 \\
\hline CPI inflation (excl. effect of ind. taxes) & 12.6 & $\ldots$ & 11.4 & 5.1 & 2.1 & 1.8 & 2.5 & 2.5 \\
\hline CPI inflation (end of period) & 18.1 & 7.0 & 7.5 & 4.2 & 3.4 & 3.0 & 2.7 & 2.4 \\
\hline Nominal GDP (bln ISK) & 1477.6 & 1472.5 & 1500.2 & 1620.5 & 1722.6 & 1816.8 & 1915.0 & 2040.3 \\
\hline \multicolumn{9}{|c|}{ (In percent of GDP, unless otherwise indicated) } \\
\hline Balance of Payments & & & & & & & & \\
\hline Current account & -15.8 & -3.4 & 3.8 & 5.4 & 1.8 & 1.6 & 1.4 & 0.2 \\
\hline Trade balance & -2.3 & 8.6 & 8.4 & 10.8 & 9.0 & 9.0 & 8.7 & 7.4 \\
\hline Net income balance 4/ & -13.2 & -11.6 & -4.1 & -4.9 & -6.9 & -7.1 & -7.1 & -6.9 \\
\hline Capital and financial account & -76.7 & 6.8 & -11.6 & -5.2 & -22.7 & 3.8 & 3.9 & 5.1 \\
\hline Capital transfer, net & -0.1 & -0.1 & -0.1 & -0.1 & -0.1 & 0.0 & 0.0 & 0.0 \\
\hline Direct investment, net & 30.9 & 8.4 & -10.1 & 4.1 & 13.3 & 6.1 & 3.1 & 9.5 \\
\hline Portfolio investment, net & 0.2 & -6.6 & 4.8 & -5.3 & -5.7 & -0.3 & 0.3 & 1.3 \\
\hline Other investment, net 5/ & -107.7 & 5.1 & -6.2 & -3.9 & -30.2 & -1.9 & 0.5 & -5.7 \\
\hline Accumulation of arrears & 158.4 & -47.2 & 0.0 & -42.6 & 0.0 & 0.0 & 0.0 & 0.0 \\
\hline Extraordinary financing & 6.8 & 61.8 & 5.6 & 64.5 & 4.9 & -3.1 & -3.9 & -3.1 \\
\hline Gross external debt $5 /$ & 564.7 & 306.9 & 295.9 & 299.0 & 256.7 & 239.0 & 226.5 & 203.1 \\
\hline Central bank reserves (US\$ billion) & 3.6 & 4.9 & 3.9 & 6.7 & 4.5 & 4.9 & 5.1 & 5.4 \\
\hline \multicolumn{9}{|l|}{ General government accounts } \\
\hline Revenue & 44.2 & 38.4 & 39.5 & 39.2 & 41.3 & 43.0 & 43.5 & 44.1 \\
\hline Expenditure & 44.8 & 52.7 & 51.9 & 48.6 & 46.6 & 44.3 & 42.0 & 41.3 \\
\hline Overall balance & -0.5 & -14.4 & -12.4 & -9.4 & -5.3 & -1.3 & 1.6 & 2.7 \\
\hline Primary balance & -0.3 & -8.3 & -6.9 & -2.7 & 1.3 & 4.3 & 6.4 & 6.9 \\
\hline Change in primary balance & -6.1 & -8.0 & -6.6 & 4.2 & 4.0 & 3.0 & 2.2 & 0.5 \\
\hline Gross debt & 71.7 & 125.2 & 105.1 & 119.9 & 110.7 & 105.0 & 97.8 & 86.6 \\
\hline Net Debt & 42.1 & 89.5 & 72.9 & 77.2 & 78.4 & 74.7 & 68.8 & 61.2 \\
\hline
\end{tabular}

Sources: $\mathrm{CBI}$; and IMF staff estimates.

$1 /$ Contributions to growth.

2/ In percent of potential output

3 / In percent of labor force.

4/ Includes interest payments due from the financial sector and income receipts to the financial sector.

5/ Including face value of old banks debt before 2009. Related interest transactions are not included from Q4 2008 on 
Table 6. Iceland: Balance of Payments, 2007-14

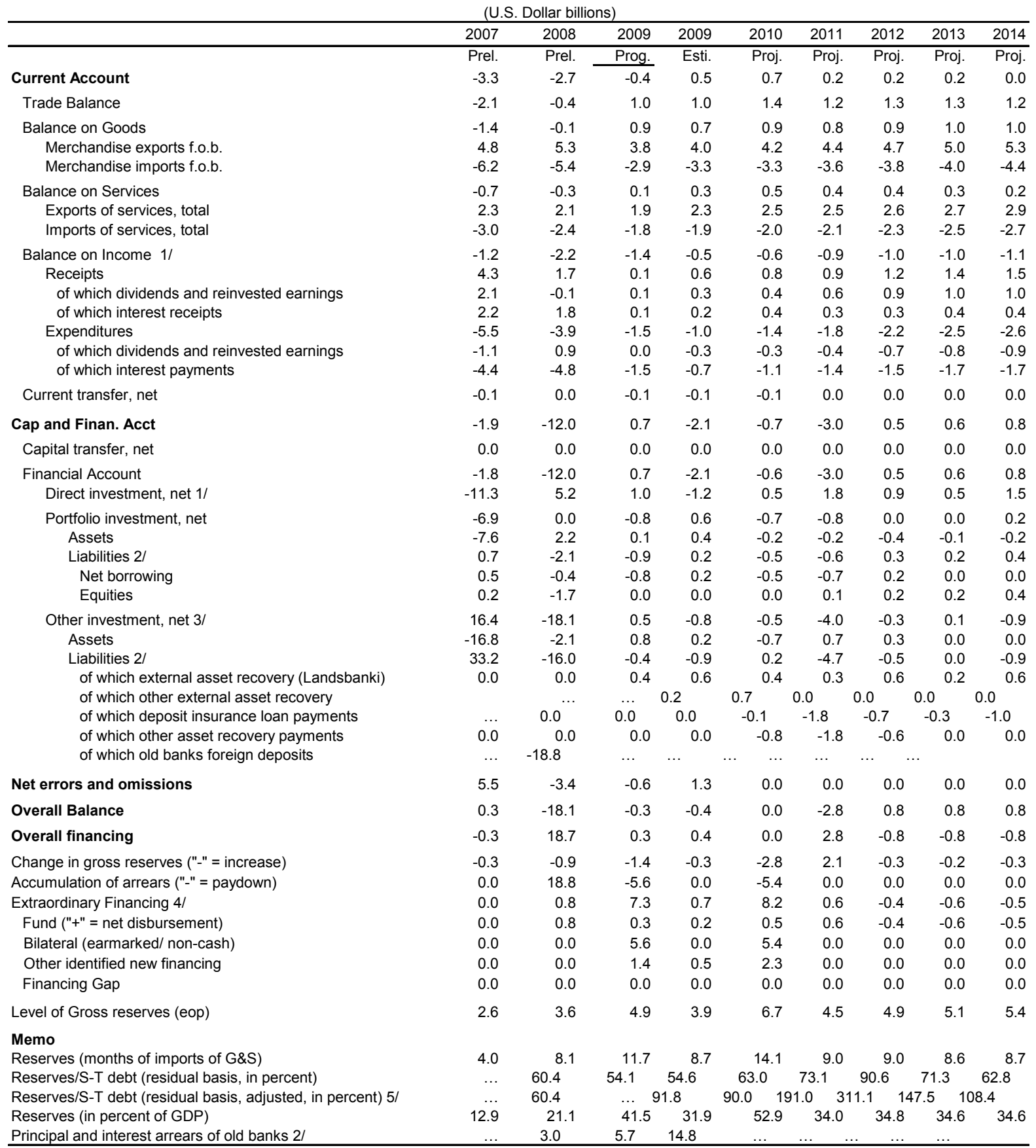

Principal and interest arrears of old banks 2

Sources: $\mathrm{CBI}$; and IMF staff estimates.

1/ 2014 data include large inflows (FDI) and outflows relating to private external debt servicing (from overseas assets).

2/ Principal and interest transactions related to old bank original obligations are not included from 4Q08 on.

3 / Includes inflows and outflows related to non-Icesave depositor obligations of Old Landsbanki.

4/ Debt service payments on extraordinary financing appear in the financial account, except for Fund repurchases.

5/ Excludes short-term debt blocked by capital controls, and maturing loan with known matching assets. 
Table 7. Iceland: General Government Operations 200744

(GFS, modified cash basis, percent of GDP 1/)

\begin{tabular}{|c|c|c|c|c|c|c|c|c|c|c|c|}
\hline & \multirow[t]{2}{*}{2007} & \multirow{2}{*}{$\begin{array}{c}2008 \\
\text { Est. }\end{array}$} & \multicolumn{3}{|c|}{2009} & \multicolumn{2}{|c|}{2010} & \multirow{2}{*}{$\begin{array}{l}2011 \\
\text { Proj. }\end{array}$} & \multirow{2}{*}{$\begin{array}{l}2012 \\
\text { Proj. }\end{array}$} & \multirow{2}{*}{$\begin{array}{l}2013 \\
\text { Proj. }\end{array}$} & \multirow{2}{*}{$\frac{2014}{\text { Proj. }}$} \\
\hline & & & Est. Accrual & Prog. & Est. Mod. Cash & Prog. & Proj. & & & & \\
\hline Total revenue $2 /$ & 47.7 & 44.2 & 42.4 & 38.4 & 39.5 & 40.5 & 39.2 & 41.3 & 43.0 & 43.5 & 44.1 \\
\hline Taxes & 37.4 & 33.9 & 31.3 & 29.7 & 30.6 & 32.6 & 30.0 & 31.7 & 32.9 & 33.2 & 33.8 \\
\hline Taxes on income and profits & 18.4 & 17.8 & 16.7 & 15.8 & 16.5 & 16.8 & 15.5 & 16.9 & 17.9 & 17.8 & 18.2 \\
\hline Personal Income Tax & 13.8 & 13.2 & 12.7 & 12.5 & 12.7 & 14.4 & 12.8 & 14.1 & 14.9 & 15.1 & 15.5 \\
\hline Corporate Income Tax & 2.5 & 1.9 & 1.2 & 0.9 & 1.2 & 1.0 & 0.9 & 1.1 & 1.2 & 0.9 & 0.9 \\
\hline Capital gains tax, rental income & 2.2 & 2.7 & 2.8 & 2.4 & 2.8 & 1.4 & 1.7 & 1.7 & 1.8 & 1.8 & 1.8 \\
\hline Taxes on payroll and workforce & 0.0 & 0.2 & 0.2 & 0.0 & 0.1 & 0.0 & 0.2 & 0.2 & 0.2 & 0.2 & 0.2 \\
\hline Taxes on property & 2.4 & 2.2 & 2.1 & 1.7 & 2.1 & 1.5 & 2.0 & 2.0 & 2.0 & 2.0 & 2.0 \\
\hline Taxes on goods and services & 16.0 & 13.2 & 11.6 & 11.4 & 11.1 & 13.3 & 11.7 & 11.9 & 12.2 & 12.5 & 12.6 \\
\hline VAT & 10.5 & 9.1 & 7.5 & 7.2 & 7.5 & 7.6 & 7.6 & 7.9 & 8.1 & 8.6 & 8.8 \\
\hline Other taxes on goods and services & 5.5 & 4.1 & 4.1 & 4.2 & 3.6 & 5.7 & 4.1 & 4.1 & 4.0 & 3.9 & 3.8 \\
\hline Taxes on international trade & 0.4 & 0.4 & 0.3 & 0.3 & 0.3 & 0.3 & 0.3 & 0.3 & 0.3 & 0.3 & 0.3 \\
\hline Other taxes & 0.1 & 0.1 & 0.4 & 0.5 & 0.4 & 0.6 & 0.3 & 0.3 & 0.3 & 0.3 & 0.3 \\
\hline Social contributions & 3.1 & 2.8 & 2.9 & 2.9 & 2.8 & 3.2 & 3.8 & 4.2 & 4.6 & 4.7 & 4.9 \\
\hline Grants & 0.1 & 0.1 & 0.1 & 0.1 & 0.1 & 0.1 & 0.1 & 0.1 & 0.1 & 0.1 & 0.1 \\
\hline Other revenue & 7.1 & 7.4 & 8.1 & 5.7 & 6.1 & 4.6 & 5.3 & 5.2 & 5.4 & 5.5 & 5.3 \\
\hline $\mathrm{o} / \mathrm{w}$ Interest income & 2.3 & 3.1 & 3.2 & 3.4 & 3.2 & 2.5 & 2.5 & 2.3 & 2.5 & 2.6 & 2.4 \\
\hline o/w Discretionary revenue measures $2 /$ & 0.0 & 0.0 & 0.0 & 1.4 & 1.4 & 5.6 & 3.8 & 3.7 & 3.5 & 3.3 & 3.1 \\
\hline Total expenditure $2 / 3 /$ & 42.3 & 44.8 & 53.4 & 52.7 & 51.9 & 51.4 & 48.6 & 46.6 & 44.3 & 42.0 & 41.3 \\
\hline Current expense $3 /$ & 39.8 & 42.1 & 51.7 & 51.1 & 50.0 & 50.9 & 48.5 & 46.3 & 44.0 & 41.5 & 40.2 \\
\hline Compensation of employees & 14.8 & 14.6 & 14.9 & 15.9 & 15.5 & 15.5 & 14.7 & 14.1 & 13.6 & 13.3 & 13.2 \\
\hline Use of goods and services & 10.8 & 11.6 & 12.5 & 12.5 & 12.0 & 12.1 & 12.2 & 11.3 & 11.1 & 10.3 & 10.3 \\
\hline Consumption of fixed capital & 1.7 & 1.8 & 2.1 & 1.9 & 2.1 & 1.9 & 2.1 & 2.1 & 2.1 & 2.1 & 2.1 \\
\hline Interest & 2.6 & 3.3 & 8.7 & 9.5 & 8.7 & 10.7 & 9.1 & 8.9 & 8.0 & 7.4 & 6.5 \\
\hline o/w Accrued on IceSave guarantee & & & 2.7 & 2.8 & 2.7 & 2.8 & 2.6 & 2.6 & 1.8 & 1.6 & 1.4 \\
\hline Subsidies & 1.8 & 1.8 & 2.0 & 2.0 & 1.4 & 1.9 & 1.3 & 1.2 & 1.2 & 1.1 & 1.1 \\
\hline Grants & 0.2 & 0.2 & 0.3 & 0.2 & 0.3 & 0.2 & 0.3 & 0.3 & 0.3 & 0.3 & 0.2 \\
\hline Social benefits & 5.8 & 6.1 & 8.2 & 6.8 & 7.7 & 6.4 & 6.8 & 6.6 & 6.0 & 5.3 & 5.3 \\
\hline Other expense & 2.2 & 2.6 & 3.0 & 2.4 & 2.2 & 2.2 & 2.1 & 1.9 & 1.9 & 1.8 & 1.6 \\
\hline Nonfinancial assets & 2.4 & 2.6 & 1.8 & 1.6 & 1.9 & 0.5 & 0.1 & 0.2 & 0.3 & 0.4 & 1.1 \\
\hline Non-financial assets, acquisition & 4.2 & 4.5 & 3.9 & 3.5 & 4.1 & 2.4 & 2.2 & 2.3 & 2.4 & 2.5 & 3.1 \\
\hline Consumption of fixed capital (-) & -1.7 & -1.8 & -2.1 & -1.9 & -2.1 & -1.9 & -2.1 & -2.1 & -2.1 & -2.1 & -2.1 \\
\hline o/w Discretionary expenditure measures $2 /$ & 0.0 & 0.0 & $\begin{array}{l}\mathbf{0 . 0} \\
0.0\end{array}$ & -0.6 & -0.6 & -2.9 & -3.4 & -3.4 & -3.2 & -3.0 & -1.1 \\
\hline Net lending/borrowing $3 /$ & 5.4 & -0.5 & -11.0 & -14.4 & -12.4 & -10.9 & -9.4 & -5.3 & -1.3 & 1.6 & 2.7 \\
\hline Net lending/borrowing incl. write-offs & 5.4 & -13.5 & -30.3 & -34.2 & -31.7 & -10.9 & $\begin{array}{r}-9.4 \\
2.9\end{array}$ & -5.3 & -1.3 & 1.6 & 2.7 \\
\hline \multicolumn{12}{|l|}{ Stock of debt 4 I } \\
\hline General government gross debt 4 / & 29.3 & 71.7 & 105.1 & 125.2 & 105.1 & 136.0 & 119.9 & 110.7 & 105.0 & 97.8 & 86.6 \\
\hline Domestic & 15.9 & 47.0 & 61.0 & 76.4 & 61.0 & 78.2 & 62.6 & 61.1 & 55.4 & 48.8 & 40.5 \\
\hline $\begin{array}{l}\text { Foreign currency } 4 \text { / } \\
\text { of which: }\end{array}$ & 13.3 & 24.7 & $\begin{array}{r}44.2 \\
0.0\end{array}$ & 48.8 & 44.2 & 57.8 & 57.3 & 49.6 & 49.7 & 49.0 & 46.1 \\
\hline Bilateral loans to support CBI reserves & 0.0 & 0.0 & 3.0 & 8.2 & 3.0 & 17.2 & 17.5 & 16.8 & 15.8 & 15.2 & 12.6 \\
\hline 'Net present value' of depositor guarantees $5 /$ & 0.0 & 0.0 & 17.0 & 17.2 & 17.0 & 19.5 & 18.3 & 19.8 & 20.6 & 21.1 & 21.3 \\
\hline Other & 13.3 & 24.7 & 24.1 & 23.3 & 24.1 & 21.1 & 21.5 & 13.0 & 13.3 & 12.7 & 12.2 \\
\hline General government net debt 6/ & 11.0 & 42.1 & 72.9 & 89.5 & 72.9 & 97.6 & 77.2 & 78.4 & 74.7 & 68.8 & 61.2 \\
\hline \multicolumn{12}{|l|}{ Structural Balances 71} \\
\hline Structural balance & 2.5 & -1.8 & -5.5 & -10.2 & -5.5 & -8.1 & -4.8 & -3.3 & 0.1 & 2.3 & 2.8 \\
\hline Structural primary balance & 3.4 & -1.2 & -1.5 & -3.7 & -1.5 & -0.2 & 1.6 & 3.1 & 5.5 & 7.1 & 6.9 \\
\hline \multicolumn{12}{|l|}{ Memo Items } \\
\hline Nominal GDP (billion ISK) & 1,309 & 1,478 & 1,500 & 1,472 & 1,500 & 1,520 & 1,621 & 1,723 & 1,817 & 1,915 & 2,040 \\
\hline Real GDP & 6.0 & 1.0 & -6.5 & -8.5 & -6.5 & -2.0 & -3.0 & 2.3 & 2.4 & 2.6 & 4.0 \\
\hline Inflation (avg) & 5.0 & 12.4 & 12.0 & 11.7 & 12.0 & 4.4 & 6.2 & 3.8 & 3.3 & 2.8 & 2.5 \\
\hline Primary balance (excl. interest income) $3 /$ & 5.7 & -0.3 & -5.6 & -8.3 & -6.9 & -2.7 & -2.7 & 1.3 & 4.3 & 6.4 & 6.9 \\
\hline Government guaranteed debt 8/ & 62.1 & 84.4 & & & & & & & & & \\
\hline Change in the primary balance 3 / & -1.0 & -6.1 & -5.2 & -8.0 & -6.6 & 5.6 & 4.2 & 4.0 & 3.0 & 2.2 & 0.5 \\
\hline
\end{tabular}

Sources: IceStat, Ministry of Finance, and Fund staff estimates.

1/ Historical data are semi-accrual; projections are modified cash

Projections for 2010 reflect the consolidation of the central government (cash) budget, and projections for local governments and social security funds.

2/ Measures have been reflected about equally divided between tax and expenditure measures, except in 2009 and 2010 when actual budget assumptions are used.

Measures are counted cumulatively from 2009 onward.

3/ Excluding write-off claims on banks. Write-offs in 2008 are the result of central bank recapitalization and securities lending contracts that failed after the bank collapse.

Write-offs in 2009 relate to an estimate of the NPV of depositor guarantees (liabilities not recovered by assets) and retroactive interest paid to new banks to compensate for late capitalization. $4 /$ Includes bilateral loans to support foreign currency reserves at the Central Bank of Iceland (CBI).

Loan from the Norwegian government directly to the CBI is excluded from general government debt. Includes the estimated net present value of the oustanding guarantee, net of asset recovery,

on the UK/Dutch IceSave loans to the Icelandic Depositors' and Investors' Guarantee Fund. Does not include Fund liabilities.

5/ Cash flow impact of the outstanding IceSave guarantee after asset recovery. It estimates, under given assumptions for asset recovery, the residual obligation for the government and growth thereof due to accruing interest.

6/ Gross debt minus liquid assets at the $\mathrm{CBI}$ (including assets from bilateral loans to support CBI reserves, which are assumed to be liquid).

$7 /$ In percent of potential GDP. Structural estimates for 2009 were normalized to account for the impact of the asset bust price cycle. The deterioration in 2009 does not reflect the fiscal stance.

8/ State guarantees only. Excludes guarantee on IceSave loans. 
Table 8. Iceland: Central Government Operations 2007-14

(GFS, modified cash basis, percent of GDP)

\begin{tabular}{|c|c|c|c|c|c|c|c|c|}
\hline & 2007 & 2008 & 2009 & 2010 & 2011 & 2012 & 2013 & 2014 \\
\hline & & Est. & Est. & Proj. & Proj. & $\overline{\text { Proj. }}$ & $\overline{\text { Proj. }}$ & Proj. \\
\hline Cash receipts from operating activities & 34.6 & 30.1 & 27.6 & 28.1 & 29.4 & 30.9 & 31.4 & 31.8 \\
\hline Tax revenue & 27.2 & 23.7 & 21.2 & 21.4 & 22.3 & 23.3 & 23.5 & 23.9 \\
\hline Taxes on income, profits, and capital gains & 11.0 & 10.3 & 9.3 & 8.7 & 9.4 & 10.0 & 10.0 & 10.2 \\
\hline Personal income tax & 6.4 & 6.0 & 5.5 & 6.0 & 6.5 & 7.1 & 7.3 & 7.5 \\
\hline Corporate income tax & 2.7 & 2.0 & 1.2 & 0.9 & 1.1 & 1.2 & 0.9 & 0.9 \\
\hline Other taxes on income and profit & 1.9 & 2.4 & 2.6 & 1.7 & 1.7 & 1.8 & 1.8 & 1.8 \\
\hline Taxes on payroll and workforce & 0.1 & 0.1 & 0.1 & 0.2 & 0.2 & 0.2 & 0.2 & 0.2 \\
\hline Taxes on property & 0.9 & 0.5 & 0.3 & 0.5 & 0.5 & 0.5 & 0.5 & 0.5 \\
\hline Taxes on sales and services & 14.7 & 12.1 & 10.8 & 11.4 & 11.6 & 11.9 & 12.2 & 12.3 \\
\hline Taxes on international trade and transactions & 0.4 & 0.4 & 0.3 & 0.3 & 0.3 & 0.3 & 0.3 & 0.3 \\
\hline Other tax revenue & 0.1 & 0.1 & 0.4 & 0.3 & 0.3 & 0.3 & 0.3 & 0.3 \\
\hline Social contributions & 3.0 & 2.8 & 2.8 & 3.8 & 4.2 & 4.6 & 4.7 & 4.9 \\
\hline Grants & 0.1 & 0.1 & 0.1 & 0.1 & 0.1 & 0.1 & 0.1 & 0.1 \\
\hline $\begin{array}{l}\text { Other receipts } \\
\text { of which: }\end{array}$ & 4.2 & 3.6 & 3.5 & 2.8 & 2.7 & 2.9 & 3.1 & 2.9 \\
\hline Interest income & 1.8 & 2.6 & 2.9 & 2.2 & 2.1 & 2.2 & 2.3 & 2.1 \\
\hline Total spending $1 /$ & 28.2 & 30.6 & 34.5 & 33.6 & 32.1 & 31.0 & 29.4 & 29.2 \\
\hline Cash payments for operating activities $1 /$ & 26.5 & 28.3 & 31.9 & 32.2 & 30.8 & 29.7 & 28.1 & 27.5 \\
\hline Compensation of employees & 8.6 & 8.5 & 8.5 & 7.9 & 7.5 & 7.2 & 7.0 & 7.2 \\
\hline Purchases of goods \& services & 5.3 & 5.6 & 5.7 & 6.0 & 5.7 & 5.6 & 5.0 & 5.1 \\
\hline Interest $2 /$ & 1.3 & 1.9 & 3.0 & 5.3 & 5.3 & 5.4 & 5.3 & 4.7 \\
\hline Transfer payments & 11.3 & 12.4 & 14.7 & 13.0 & 12.2 & 11.5 & 10.8 & 10.6 \\
\hline Net cash inflow from operating activities & 8.1 & 1.8 & -4.3 & -4.1 & -1.4 & 1.1 & 3.3 & 4.3 \\
\hline Investments in NFAs & 1.7 & 2.3 & 2.5 & 1.4 & 1.3 & 1.3 & 1.3 & 1.7 \\
\hline Surplus / deficit (before adjustment to cash) & 6.3 & -0.5 & -6.8 & -5.5 & -2.7 & -0.2 & 2.1 & 2.6 \\
\hline Adjustment to cash & -1.7 & 0.8 & -0.9 & 0.0 & 0.0 & 0.0 & 0.0 & 0.0 \\
\hline Overall deficit (incl. adjustment to cash) & 4.7 & 0.3 & -7.7 & -5.5 & -2.7 & -0.2 & 2.1 & 2.6 \\
\hline $\begin{array}{l}\text { Write-offs } \\
\text { of which: }\end{array}$ & 0.0 & 13.0 & 19.3 & 0.0 & 0.0 & 0.0 & 0.0 & 0.0 \\
\hline $\mathrm{CBI}$ recapitalization related write-offs & 0.0 & 11.8 & 0.0 & 0.0 & 0.0 & 0.0 & 0.0 & 0.0 \\
\hline Securities lending related write-offs & 0.0 & 1.2 & 0.0 & 0.0 & 0.0 & 0.0 & 0.0 & 0.0 \\
\hline Called guarantees & 0.0 & 0.0 & 17.4 & 0.0 & 0.0 & 0.0 & 0.0 & 0.0 \\
\hline Retro-active interest on bank capitalization & 0.0 & 0.0 & 1.9 & 0.0 & 0.0 & 0.0 & 0.0 & 0.0 \\
\hline Augmented Balance & 4.7 & -12.7 & -27.0 & -5.5 & -2.7 & -0.2 & 2.1 & 2.6 \\
\hline \multicolumn{9}{|l|}{ Memorandum Items: } \\
\hline Nominal GDP & 1,309 & 1,478 & 1,500 & 1,621 & 1,723 & 1,817 & 1,915 & 2,040 \\
\hline Inflation (avg) & 5.0 & 12.4 & 12.0 & 6.2 & 3.8 & 3.3 & 2.8 & 2.5 \\
\hline Real GDP growth & 6.0 & 1.0 & -6.5 & -3.0 & 2.3 & 2.4 & 2.6 & 4.0 \\
\hline Output gap 3/ & 3.7 & 1.8 & -2.9 & -3.5 & -2.1 & -1.7 & -0.9 & 0.0 \\
\hline Accrued interest on inflation indexed bonds/lcesav & .. & .. & 4.2 & 3.0 & 2.9 & 2.1 & 1.8 & 1.7 \\
\hline Deficit incuding accrued interest $4 /$ & .. & .. & -11.9 & -8.5 & -5.6 & -2.3 & 0.3 & 0.9 \\
\hline Net financial balance 4/ & .. & .. & -11.8 & -8.1 & -4.1 & -1.2 & 0.9 & 1.5 \\
\hline Primary balance (excl. interest income) & 5.8 & -1.3 & -6.7 & -2.4 & 0.6 & 3.0 & 5.1 & 5.1 \\
\hline New discretionary measures & .. & .. & 2.0 & 5.3 & 0.2 & 0.1 & -0.1 & -1.5 \\
\hline
\end{tabular}

1/ Measures have been reflected as about equally divided between revenue and spending measures, except in 2009. 2/ Interest paid cash. Excludes accrued interest from inflation indexed bonds.

$3 /$ Actual output less potential output in percent of potential output.

4 / Includes accrued interest on guarantee for IceSave-related loans and accrued interest on inflation indexed bonds. 
Table 9. Iceland: Fiscal Measures in 2010

(in percent of GDP)

\begin{tabular}{ll} 
Revenue measures 1/ & $\mathbf{2 . 5}$ \\
Reform of income taxes & $\mathbf{0 . 8}$ \\
VAT & $\mathbf{0 . 2}$ \\
Introduction of third bracket at 14 percent & 0.1 \\
Increase of upper bracket from 24.5 to 25 percent & 0.1 \\
Excises & $\mathbf{0 . 1}$ \\
10 percent increase in alcohol & 0.1 \\
10 percent increase in tobacco & 0.0 \\
3.2 percent increase in diesel fuel & 0.0 \\
4.3 percent increase in petrol & 0.0 \\
10 percent increase in car tax & 0.0 \\
Energy tax & $\mathbf{0 . 3}$ \\
Introduction of 0.12 ISK energy tax per Kwh & 0.1 \\
Tax on hot water 2 percent on sale of geothermal hot water & 0.0 \\
Pre-payment of CIT from large energy users & 0.0 \\
Carbon tax & 0.2 \\
Social Security Contributions & $\mathbf{0 . 7}$ \\
Introduction of tax on wealthy individuals & $\mathbf{0 . 2}$ \\
Other & $\mathbf{0 . 1}$ \\
& \\
Expenditure measures & $\mathbf{3 . 2}$ \\
Operating expenditures & 0.3 \\
Transfers & 1.6 \\
Maintenance and capital investment & 1.2 \\
\hline
\end{tabular}

$1 /$ Measures do not equal the increase in primary revenues from 2009 to 2010 due to one-off factors in 2009, and discretionary revenue developments in 2010. 
Table 10. Iceland: Changes to Capital Controls Rules

\begin{tabular}{|c|c|c|}
\hline & Previous regime & $\begin{array}{c}\text { New Regime } \\
\text { (from end-October } 2009 \text { onwards) }\end{array}$ \\
\hline $\begin{array}{l}\text { New inward } \\
\text { investments in } \\
\text { FX }\end{array}$ & $\begin{array}{l}\text { - Only direct investment and real estate } \\
\text { transactions or reinvestments by } \\
\text { foreign parties allowed. } \\
\text { - Proceeds from the sale of direct } \\
\text { investment are not transferable. }\end{array}$ & $\begin{array}{l}\text { - New inflows of FX for the purpose of } \\
\text { investing in Iceland are allowed, except } \\
\text { derivative transactions. } \\
\text { - Proceeds from new investment in FX } \\
\text { are transferable. }\end{array}$ \\
\hline $\begin{array}{l}\text { Transactions in } \\
\text { domestic } \\
\text { currency }\end{array}$ & $\begin{array}{l}\text { - Transfer of ISK funds from abroad } \\
\text { and between residents and non- } \\
\text { residents in connection with the } \\
\text { purchase and sale of ISK denominated } \\
\text { financial instruments and for other } \\
\text { transactions except for export } \\
\text { payments allowed. }\end{array}$ & $\begin{array}{l}\text { - Transfer of ISK funds between } \\
\text { residents and non-residents or between } \\
\text { a foreign and a local ISK account } \\
\text { prohibited unless in connection with the } \\
\text { purchase and sale of (i) ISK } \\
\text { denominated financial instruments, (ii) } \\
\text { real estate in Iceland, and (iii) goods } \\
\text { and services, except payment for } \\
\text { exports through a local ISK bank } \\
\text { account including foreign banks' vostro } \\
\text { accounts. }\end{array}$ \\
\hline $\begin{array}{l}\text { Real estate } \\
\text { transactions }\end{array}$ & $\begin{array}{l}\text { Resident's purchase of real estate } \\
\text { abroad allowed. }\end{array}$ & $\begin{array}{l}\text { Residents' purchase of real estate } \\
\text { abroad not allowed, unless related to } \\
\text { change in residence. }\end{array}$ \\
\hline $\begin{array}{l}\text { Miscellaneous } \\
\text { movement of } \\
\text { capital }\end{array}$ & $\begin{array}{l}\text { - Movement of capital for gifts, } \\
\text { subsidies or other purposes in amounts } \\
\text { exceeding ISK } 10 \text { million is prohibited. } \\
\text {-Foreign exchange transactions for the } \\
\text { purchase of goods abroad by residents } \\
\text { allowed. }\end{array}$ & $\begin{array}{l}\text { - Movement of capital for gifts, } \\
\text { subsidies or other purposes in amounts } \\
\text { exceeding ISK } 5 \text { million is prohibited. } \\
\text { - Foreign exchange transactions for the } \\
\text { purchase of goods abroad by residents } \\
\text { allowed only if imported and related to } \\
\text { the business operation of the resident. }\end{array}$ \\
\hline Exemptions & $\begin{array}{l}\text { Exemptions from all rules apply to: } \\
\text { (i) The treasury and companies owned } \\
\text { by the Treasury } \\
\text { (ii) Municipalities and their companies } \\
\text { (iii) Companies that are parties to } \\
\text { investment agreements with the } \\
\text { government } \\
\text { (iv) Companies granted permission by } \\
\text { the Ministry of Industry to search for oil } \\
\text { (v) Resolution committees } \\
\text { (vi) Companies with over } 80 \% \text { of their } \\
\text { expenses and income in foreign } \\
\text { currency abroad (partly exempt). }\end{array}$ & $\begin{array}{l}\text { - Entities in (i) and (ii) are exempt from } \\
\text { rules on investments abroad including } \\
\text { financial instruments and lending using } \\
\text { their own foreign currency. } \\
\text { - Entities in (iii) and (iv) are exempt } \\
\text { from the rules except for the purchase } \\
\text { of foreign currency and derivative } \\
\text { transactions. } \\
\text { - Resolution committees (v) } \\
\text { are exempt from prohibitions on } \\
\text { transferring ISK cross-border, } \\
\text { investments abroad including lending } \\
\text { and the repatriation requirement, but } \\
\text { may not buy FX for ISK. } \\
\text { - Entities in (vi) may be exempt from } \\
\text { rules on investments abroad including } \\
\text { lending and the repatriation } \\
\text { requirement. } \\
\text { - Commercial banks, savings banks } \\
\text { and other credit institutions are allowed } \\
\text { to lend abroad and are exempt from } \\
\text { the repatriation requirement. }\end{array}$ \\
\hline
\end{tabular}

Source: CBI. 
Table 11. Iceland: Bank Capitalization

\begin{tabular}{|c|c|c|c|c|c|}
\hline & \multirow{2}{*}{$\begin{array}{c}\text { Total } \\
\text { recapitalization } \\
\text { (ISK billion) } \\
\end{array}$} & \multicolumn{3}{|c|}{ Government contribution } & \multirow[t]{2}{*}{ Status } \\
\hline & & $\begin{array}{l}\text { Government equity } \\
\text { (in ISK bn) }\end{array}$ & $\begin{array}{l}\text { Government share } \\
\quad \text { (in percent) }\end{array}$ & $\begin{array}{l}\text { Tier } 2 \text { capital } \\
\text { (in ISK bn) }\end{array}$ & \\
\hline \multicolumn{6}{|l|}{ A. Commercial banks } \\
\hline Landsbankinn & 150 & 122 & 81 & 0 & $\begin{array}{l}\text { Compensation agreement reached on } 12 \text { October 2009. Recapitalized } \\
\text { and acquired by the government on } 16 \text { December } 2009 .\end{array}$ \\
\hline & & & & & $\begin{array}{l}\text { Compensation to the Old Landsbanki: ISK } 260 \text { billion ten year bond. A } \\
\text { review of the valuation of a substantial portion of the loan portfolio } \\
\text { transferred in October } 2008 \text { shall be conducted up to December } 2012 \text {. } \\
\text { As a result of that review, the size of the bonds issued to Old } \\
\text { Landsbanki may be increased by up to approximately ISK } 90 \text { billion. In } \\
\text { this event, the issue of additional bonds will be accompanied by a } \\
\text { corresponding release of the equity issued to Old Landsbanki at } \\
\text { closing. }\end{array}$ \\
\hline Arion (New Kaupthing) & 72 & 9 & 13 & 24 & $\begin{array}{l}\text { Compensation agreement reached on } 20 \text { July 2009. Recapitalization } \\
\text { completed on } 4 \text { September } 2009 \text {. Acquired by the resolution committee } \\
\text { of Kaupthing on } 1 \text { December } 2009 \text {. }\end{array}$ \\
\hline Islandsbanki & 65 & 3 & 5 & 25 & $\begin{array}{l}\text { Compensation agreement reached on } 20 \text { July 2009. Recapitalization } \\
\text { completed on } 13 \text { September 2009. Acquired by the Resolution } \\
\text { Committee of Glitnir on } 15 \text { October } 2009 \text {. }\end{array}$ \\
\hline \multicolumn{6}{|l|}{ B. Saving banks } \\
\hline BYR sparisjỗ & $\cdots$ & $\cdots$ & ... & .. & $\begin{array}{l}\text { Negotiations between creditors and shareholders on capitalization has } \\
\text { been completed. Final capitalization options are under consideration by } \\
\text { creditors and expected to be completed by end-May } 2010 \text {. }\end{array}$ \\
\hline Sparisjỡur Kaflavíkur & $\ldots$ & $\ldots$ & $\ldots$ & .. & $\begin{array}{l}\text { Negotiations between creditors and shareholders on capitalization has } \\
\text { been completed. Final capitalization options are under consideration by } \\
\text { creditors and expected to be completed by end-May } 2010 \text {. }\end{array}$ \\
\hline Other saving banks & $\cdots$ & $\cdots$ & $\cdots$ & .. & $\begin{array}{l}\text { Negotiations between creditors and shareholders on capitalization has } \\
\text { been completed. Final capitalization options are under consideration by } \\
\text { creditors and expected to be completed by end-May } 2010 \text {. }\end{array}$ \\
\hline
\end{tabular}

Source: Ministry of Finance, Iceland. 
Table 12. Iceland: Current Household Debt Restructuring Framework

\begin{tabular}{|c|c|c|c|c|}
\hline & Temporary crisis measures & General debt rescheduling & Voluntary workout measures & Court-supervised procedures \\
\hline Key features & $\begin{array}{l}\text { Moratorium on foreclosures and } \\
\text { temporary payment freezing }\end{array}$ & $\begin{array}{l}\text { Generalized payment smoothing } \\
\text { on mortgages and auto } \\
\text { loans/leases }\end{array}$ & $\begin{array}{l}\text { Guidelines on voluntary debt } \\
\text { restructuring for individuals } \\
\text { (October Agreements) 1/ }\end{array}$ & $\begin{array}{c}\text { Court-supervised temoprary mitigation under } \\
\text { composition agreements (Act No.24/2009) \& } \\
\text { temporary mitigation of residential mortgage } \\
\text { payments (Act No. 50/2009) 2/ }\end{array}$ \\
\hline 1 Participation and target group & $\begin{array}{l}\text { All households with mortgages } \\
\text { on foreclosures. Payment } \\
\text { freeze applied to all household } \\
\text { debts. }\end{array}$ & $\begin{array}{l}\text { All CPl-indexed and FX- } \\
\text { indexed mortgages and auto } \\
\text { loans borrowers. }\end{array}$ & $\begin{array}{l}\text { Distressed borrowers with } \\
\text { payment capacity exceeds } 110 \% \\
\text { (80\% in some circumstances) of } \\
\text { mortgaged asset value. }\end{array}$ & $\begin{array}{l}\text { Distressed mortgage borrowers in situations } \\
\text { where other available measures do not suffice } \\
\text { under Act No.50/2009; distressed borrowers } \\
\text { unable to abide by his financial commitments } \\
\text { in the forseeable future on his/her unsecured } \\
\text { claims under (Act No.24/2009). }\end{array}$ \\
\hline 2 Application deadline & $\begin{array}{l}\text { Moratorium extended until Oct- } \\
\text { 2010; payment freeze was } \\
\text { lifted. }\end{array}$ & No & $\begin{array}{l}\text { Yes, varies by individual financial } \\
\text { institutions. }\end{array}$ & No \\
\hline $\begin{array}{l}3 \text { Requirements/eligibility for } \\
\text { application }\end{array}$ & - & $\begin{array}{l}\text { Applied to all CPI-indexed } \\
\text { unless opt-out; opt-in for FX- } \\
\text { indexed mortgage loans. For } \\
\text { car loans not in default and } \\
\text { taken prior to Oct- } 08 \text {. }\end{array}$ & $\begin{array}{l}\text { Apply to principal bank with } \\
\text { information for credit assessment }\end{array}$ & Submit applications/petitions to courts. \\
\hline 4 New payment schedule & $\begin{array}{l}\text { Freeze on payments on } \\
\text { principals and/or interests. }\end{array}$ & $\begin{array}{l}\text { Based on payment smoothing } \\
\text { index published by Statistics } \\
\text { Iceland. Maturity extension by } \\
\text { max. of } 3 \text { years. }\end{array}$ & $\begin{array}{l}\text { Based on capacity to pay and } \\
\text { negotiation with creditors. }\end{array}$ & $\begin{array}{l}\text { Revised monthly payment determined by the } \\
\text { court-appointed supervisor. }\end{array}$ \\
\hline 5 Period of availability of measure & $\begin{array}{l}\text { Oct } 2008 \text { - now for foreclosures; } \\
\text { Oct } 2008 \text { - early } 2009 \text { for } \\
\text { temporary payment freeze on } \\
\text { FX loans. }\end{array}$ & $\begin{array}{l}\text { Nov } 09 \text { to end-12 for } \\
\text { mortgages; Nov } 09 \text { to end-10 } \\
\text { for auto loans }\end{array}$ & $\begin{array}{l}\text { Guidelines effective from Nov } 2009 \\
\text { to end-2012 }\end{array}$ & N.A. \\
\hline 6 Options for write-offs & N.A. & $\begin{array}{l}\text { Remaining outstanding loans } \\
\text { written off after 3-year } \\
\text { extension if honoring interim } \\
\text { payments. }\end{array}$ & $\begin{array}{l}\text { Remaining balance to be written- } \\
\text { off if interim payments are made; } \\
\text { repayment capacity re-assessed } \\
\text { in some circumstances before } \\
\text { write-offs. }\end{array}$ & $\begin{array}{l}\text { Debtor's payment capacity reassessed; } \\
\text { debtors can request cancellation on the lien } \\
\text { subject to no payment arrears under Act } \\
\text { No.50/2009. }\end{array}$ \\
\hline 7 Take-up rates $3 /$ & N.A. & $\begin{array}{l}45 \% \text { of } \mathrm{CPI} \text {-indexed and } 42 \% \\
\text { of FX-linked mortgages; } 15 \% \text { of } \\
\text { auto loans }\end{array}$ & $\begin{array}{l}\text { About } 20 \% \text { of claims are under } \\
\text { some form of restructuring } \\
\text { consideration by banks. }\end{array}$ & $\begin{array}{l}\text { Under Act No.50/2009, about } 130 \text { applications } \\
\text { as of end-09, of which } 52 \% \text { approved and } 37 \% \\
\text { pending. }\end{array}$ \\
\hline 8 Duration it takes to process $3 /$ & N/A; automatically enrolled & N/A; automatically enrolled & 1-3 months & $\begin{array}{l}2-4 \text { months for applications under Act } \\
\text { No.50/2009. }\end{array}$ \\
\hline
\end{tabular}

Sources: Icelandic authorities and private creditors.

$1 /$ Some creditors/banks offer a variety of voluntary work-out measures beyond the minimum requirements in the agreed guidelines, including payment smoothing (greidslujofnun) to specific groups of debtors, loan conversion with NPV reduction, interest rate reimbursements, reduction of interest rates, maturity extension, and possibility of debt write-offs.

2/ The rules for 'Temporary Mitigation under Composition Agreements' (Act No. 24/2009) were established. The Act applies to contractural claims that are not secured by mortgages.

The claims secured by mortgages are covered by the rules of mitigation of residential mortgage payments under Act No. 50/2009.

3/ Estimates for take-up rates and average duration based on best available information gathered from banks and courts data. Duration varies case by case. 
Table 13. Iceland: Corporate Debt Restructuring Framework

\begin{tabular}{|l|l|}
\hline \multicolumn{1}{|c|}{ Impediments } & \multicolumn{1}{c|}{ Policy recommendations } \\
\hline $\begin{array}{l}\text { 1. Conflict of interests among different classes of } \\
\text { claimants }\end{array}$ & $\begin{array}{l}\text { - Restructuring guidelines to include lead creditors' authority } \\
\text { and power; provision on new financing and rules on } \\
\text { voluntary stay of payments }\end{array}$ \\
\hline 2. Asymmetric information between firms and creditors & $\begin{array}{l}\text { - Regular independent valuation of loans, collateral and } \\
\text { restructuring progress } \\
\text { - Restructuring guidelines to ensure timely information flows } \\
\text { from debtors to creditors }\end{array}$ \\
\hline 3. Connected lending & - Enhanced supervision including onsite examination \\
\hline 4. Restructuring and financial capacity of claimholders & $\begin{array}{l}\text { - A generalized approach to restructuring of SMEs' debts } \\
\text { - Incorporation of FX loans to unhedged borrowers into the } \\
\text { computation of market risk } \\
- \text { Enhanced supervision and regular independent valuation of } \\
\text { loans, collateral and restructuring progress }\end{array}$ \\
\hline
\end{tabular}

Source: IMF staff. 
Table 14. Iceland: Proposed Changes in the Insolvency Regime

\begin{tabular}{|c|c|}
\hline & Proposed changes \\
\hline $\begin{array}{l}\text { 1. To simplify the } \\
\text { procedures for in- } \\
\text { court debt } \\
\text { restructuring } \\
\text { agreements }\end{array}$ & $\begin{array}{l}\text { - Streamline the requirements for debtors to file petitions to the court to seek } \\
\text { agreement with creditors } \\
\text { - Facilitate the modification of the restructuring proposal by the debtor } \\
\text { - Reduce time to reach restructuring agreements by permitting creditors to } \\
\text { vote at the time of submission of their claims } \\
\text { - Introduce as a requirement for court approval of the agreement that the } \\
\text { debtor demonstrate capacity to repay the debt under the terms of the } \\
\text { restructuring agreement }\end{array}$ \\
\hline $\begin{array}{l}\text { 2. To expedite the } \\
\text { exit of unviable } \\
\text { debtors }\end{array}$ & $\begin{array}{l}\text { - Introduce new grounds for creditors to seek bankruptcy for defaulted and } \\
\text { unviable debtors } \\
\text { - Make corporate managers liable for costs resulting from undue delay of the } \\
\text { creditors' recovery }\end{array}$ \\
\hline $\begin{array}{l}\text { 3. To facilitate cross- } \\
\text { border insolvency } \\
\text { proceedings }\end{array}$ & $\begin{array}{l}\text { - Allow a debtor or foreign bankruptcy trustee to seek assistance from } \\
\text { Icelandic courts even in the absence of an international treaty }\end{array}$ \\
\hline $\begin{array}{l}\text { 4. To provide } \\
\text { incentives for } \\
\text { creditors to engage } \\
\text { in restructuring }\end{array}$ & - Ensure that creditors' rights ar e not impaired without their consent \\
\hline $\begin{array}{l}\text { 5. To improve } \\
\text { institutional capacity } \\
\text { of handling } \\
\text { bankruptcy and } \\
\text { restructuring cases }\end{array}$ & $\begin{array}{l}\text { - Increase the number of District Court judges } \\
\text { - Implement additional institutional arrangements to facilitate out-of-court debt } \\
\text { workouts with mechanisms such as 'mediation or Debtors'Ombudsman" }\end{array}$ \\
\hline
\end{tabular}

Source: Icelandic Authorities and IMF staff. 
Table 15. Iceland: External Financing Requirement and Sources, 2009-14 (In billions of US dollars)

\begin{tabular}{|c|c|c|c|c|c|c|}
\hline & $\begin{array}{r}2009 \\
\text { Proj } \\
\end{array}$ & $\begin{array}{r}2010 \\
\text { Proj } \\
\end{array}$ & $\begin{array}{r}2011 \\
\text { Proj } \\
\end{array}$ & $\begin{array}{r}2012 \\
\text { Proj } \\
\end{array}$ & $\begin{array}{r}2013 \\
\text { Proj } \\
\end{array}$ & $\begin{array}{r}2014 \\
\text { Proj } \\
\end{array}$ \\
\hline A Gross Requirements & 6.1 & 6.9 & 11.0 & 6.3 & 5.3 & 7.3 \\
\hline Current account deficit & -0.5 & -0.7 & -0.2 & -0.2 & -0.2 & 0.0 \\
\hline Amortization (MLT) & 1.5 & 1.7 & 4.3 & 1.6 & 1.1 & 3.0 \\
\hline Official (excl. IMF) & 0.8 & 0.6 & 1.7 & 0.4 & 0.2 & 0.4 \\
\hline Deposit insurance loans & 0.0 & 0.1 & 1.8 & 0.7 & 0.3 & 1.0 \\
\hline Private & 0.7 & 1.1 & 0.8 & 0.5 & 0.6 & 1.6 \\
\hline Short-term debt & 5.0 & 5.8 & 6.9 & 4.9 & 4.4 & 4.3 \\
\hline B Sources of Financing & 4.8 & 4.1 & 10.3 & 6.7 & 5.8 & 7.8 \\
\hline Foreign Direct Investment (net) & -1.2 & 0.5 & 1.8 & 0.9 & 0.5 & 1.5 \\
\hline FDI outflows Abroad & -1.0 & 0.2 & 1.0 & 0.1 & -0.1 & 0.9 \\
\hline FDI inflows to Iceland & -0.2 & 0.3 & 0.8 & 0.8 & 0.5 & 0.5 \\
\hline Net inflows of equity and other capital & 0.4 & -0.1 & -0.1 & -0.2 & 0.1 & 0.2 \\
\hline Disbursements (MLT) & 1.2 & 0.8 & 1.7 & 1.2 & 1.0 & 1.5 \\
\hline Short-term debt & 3.8 & 6.5 & 4.1 & 4.9 & 4.5 & 4.9 \\
\hline Other net assets & 0.9 & -0.8 & 0.6 & 0.2 & 0.0 & 0.0 \\
\hline Reserves accumulation (-: increase) & -0.3 & -2.8 & 2.1 & -0.3 & -0.2 & -0.3 \\
\hline C Financing Gap (A-B) & 1.3 & 2.8 & 0.6 & -0.4 & -0.6 & -0.5 \\
\hline Errors and omissions & 1.3 & 0.0 & 0.0 & 0.0 & 0.0 & 0.0 \\
\hline Accumulation of arrears & 0.0 & -5.4 & 0.0 & 0.0 & 0.0 & 0.0 \\
\hline Extraordinary Financing & 0.7 & 8.2 & 0.6 & -0.4 & -0.6 & -0.5 \\
\hline Fund & 0.2 & 0.5 & 0.6 & -0.4 & -0.6 & -0.5 \\
\hline Bilateral (earmarked/ non-cash) & 0.0 & 5.4 & 0.0 & 0.0 & 0.0 & 0.0 \\
\hline Other identified new financing & 0.5 & 2.3 & 0.0 & 0.0 & 0.0 & 0.0 \\
\hline Residual Financing gap & 0.0 & 0.0 & 0.0 & 0.0 & 0.0 & 0.0 \\
\hline
\end{tabular}

Sources: CBI; and IMF staff estimates. 


\section{Appendix I. Debt Sustainability Analysis}

1. This Appendix analyzes external and public debt sustainability in detail. The discussion encompasses revisions made to the assumptions used in past assessments, a baseline scenario, and a detailed discussion of various stress tests. To anticipate, the assessment has not changed since the first review: while debt levels are expected to remain high, they should remain on a downward trajectory, even under stress test scenarios, provided there is strict program implementation.

\section{A. External Debt Sustainability}

2. Several assumptions underlying the analysis have been changed, reflecting new information since the time of the first review (Table A1):

- $\quad$ The total legacy private external debt stock has been revised upwards, largely due to a better understanding of the amount of domestic assets in the old banks (Table 4).

- $\quad$ FDI in the energy-intensive sector is now expected to be mostly debt-creating rather than pure equity, resulting in an accumulation of about 20 percent of GDP in debt over the medium-term.

- $\quad$ Nordic/BIS short-term swaps with the central bank have been eliminated in December 2009, in line with repayments in December, while Nordic loans to the government have been shifted from 2009 to 2010, reflecting the expected timing of the coming reviews, and the drawdown of only two-thirds of the first tranche of the loan.

- $\quad$ Projected market borrowing by the government has been adjusted in line with the medium-term public debt management plan.

- $\quad$ Adjustments have been made to the profile of recovery and payment of assets by Resolution Committees (RCs) of old banks. The profile now shows a build-up of recovered assets, contributing to higher gross external liabilities, until their release in 2011 (i.e. after expected legal challenges are wound up). After that, recovered FX-denominated assets are assumed to be paid out on receipt. Assets are only reflected as an external liability once they are actually recovered.

- $\quad$ Adjustments have been made concerning expected recovery and disposal by the central bank of less-liquid external assets acquired during the financial crisis. Some 10 percent of GDP is expected to be realized by 2011.

- Capital outflow projections have been adjusted: the second-stage release (longer term assets) is assumed to be more gradual. Regarding the third stage (short-term assets), the assumption remains that debt is almost fully rolled. The projections continue to assume some circumvention of capital controls. 


\section{The path of interest rates} remains similar to that at the time of the first review. Rates on market debt are initially high, in line with present high nominal rates (reflecting inflation, risk premia, and the monetary policy stance), and then gradually fall over the medium term as conditions stabilize.

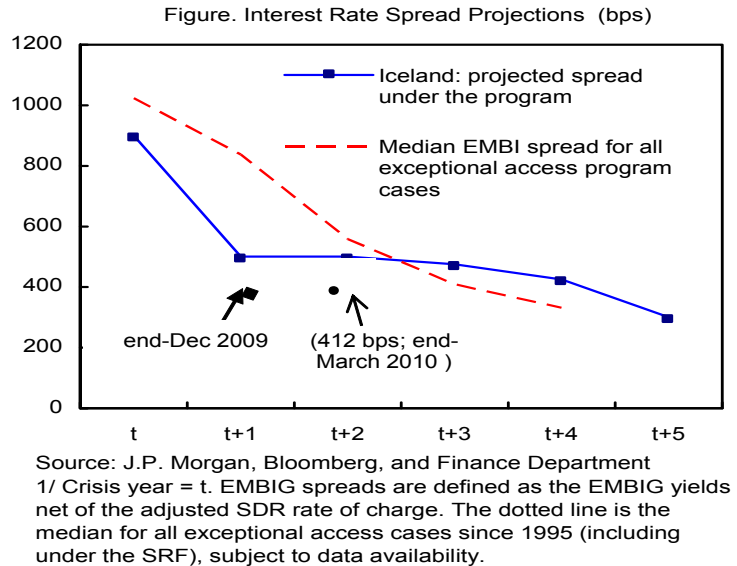

4. Under the program macroeconomic baseline, external debt is projected to peak at about 300 percent of GDP in 2010 and to fall slowly to around 203 percent of GDP by 2014 (Table A1; Figure A1). Key factors driving the decline include asset recovery, deleveraging by Icelandic multinationals, private sector debt restructuring, and current account dynamics. Indeed, by the end of the period, Iceland's non-interest current account balance (15 percent of GDP) is well above the debt-stabilizing level ( 0.1 percent of GDP), suggesting that external debt reductions will continue in the medium-term.

5. Stress tests suggest that the downward trajectory is a robust result, provided the program is implemented (Figure A1):

- $\quad$ Asset recovery shock. Reduced external asset recovery (equivalent to 20 percent of GDP) would slow but not stop the downward trajectory of debt.

- Additional debt shock. In the event of a 20 percent of GDP shock to external debt (e.g. from contingent liabilities, or due to revised estimates), the external debt ratio would remain on a downward trajectory.

- Interest rate shock. A permanent increase in the risk premium of about $150 \mathrm{bps}$ would slow, but not stop, the downward trajectory of debt.

- $\quad$ Exchange rate shock. A permanent depreciation of 30 percent would drive up external debt as a percent of GDP to a much higher level, although the downward trajectory would be expected to resume.

- Current account shock. A permanent deterioration in the non-interest current account deficit (e.g. due to a terms-of-trade shock, or revised estimates of debt and debt service) would slow, but not prevent, projected reductions in the external debt ratio. 
- Downside scenario. A low growth, high interest rate, depreciated exchange rate scenario can still be consistent with a downward trajectory for debt, provided that the low-growth trap is not too deep.

- $\quad$ Historical scenario. This leads to negative debt dynamics, but is not thought likely. The collapse of the banking sector was a permanent shock, and the events of the 2003-07 boom are unlikely to be repeated any time soon.

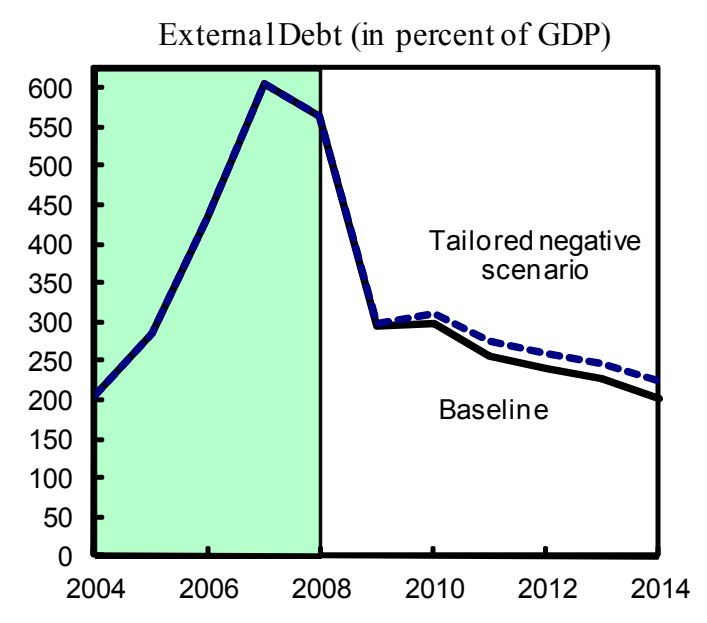

\section{B. Public Debt Sustainability}

6. Several assumptions underlying the analysis have been changed, reflecting new information since the time of the first review:

- $\quad$ The adjustment path for the general government primary balance now reflects a $4 \frac{1}{4}$ percent of GDP improvement in 2010, instead of the 5 $\frac{1}{2}$ percent of GDP assumed at the First Review. The medium-term adjustment path remains unchanged.

- $\quad$ The impact of bank capitalization on debt has been lowered reflecting the sale of equity in two of the three new banks back to their creditors. Taken together, the bank recapitalization now amount to ISK 183 billion, compared with ISK 270 billion at the time of the First Review.

- $\quad$ The Icesave assessment has been updated. Recovery is now expected to be higher (around 90 percent of deposits), but accrued interest will also be higher, as payouts are delayed to 2011 due to legal challenges. The impacts largely offset each other, and the total residual public obligation is still estimated to be between 15 and 20 percent of 2014 GDP, under the provisions in the August 2009 agreement (ongoing negotiations, which are converging on an interest holiday up to the present, suggest that the ultimate cost could be significantly lower).

- $\quad$ The projected drawdown of deposits has been reduced, to preserve coverage of at least 6 months of financing needs (the target in the public debt management plan). This increases gross financing needs and gross debt, but does not affect 'net' debt.

- $\quad$ Projections now include disposal of assets acquired by the government during the crisis. The projected disposals averages 1 percent of GDP per year during 2011-14. 
- The timing and rollover rates for external loans have been adjusted in line with assumptions used for the external debt analysis.

7. Under the program baseline scenario, Iceland's public debt declines slowly but continuously over the medium term (Table A2, Figure A2). This downward trajectory continues to be driven by the consolidation plan and the gradual improvement of the real interest rate/GDP growth differential. The peak of debt in 2010 reflects the disbursement of bilateral loans. By end-period, the actual primary balance would exceed the debt-stabilizing level, implying that debt reductions would continue beyond the projection period.

8. In line with findings at the First Review, stress tests suggest that the downward trajectory for debt is a reasonably robust result, provided the program is implemented, (Figure A2):

- Macro shocks. An interest rate shock or growth shock would raise the level of debt, but not reverse the path for public debt, given implementation of the fiscal consolidation plan.

- $\quad$ Contingent liability shock. A shock to public debt of 30 percent of GDP (e.g. arising from public enterprises, or the need to inject further capital in the banking sector) would lead to debt peaking above 160 percent of GDP in 2011. Provided that the fiscal consolidation path is maintained, and there are no significant side effects on interest rates, public debt would start to come down.

Public debt (in percent of GDP)

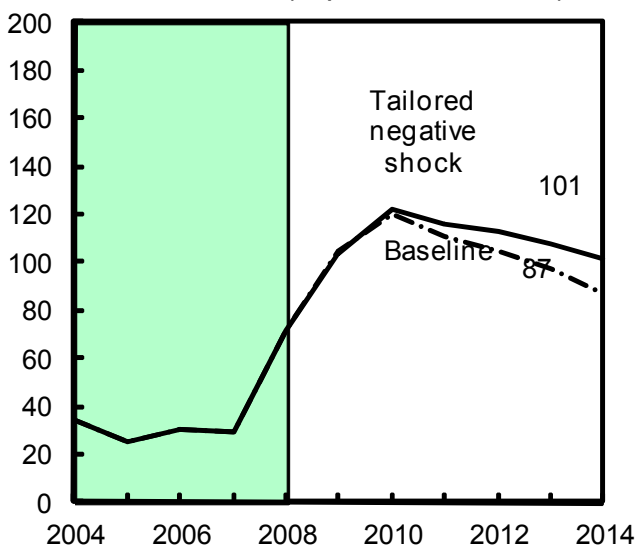

- Downside scenario. A low growth, high interest rate, depreciated exchange rate scenario can still be consistent with a downward trajectory for public debt, provided that the low-growth trap is not too deep, and that the consolidation path can be maintained.

- No policy change scenario. No policy change would imply a continuation of double digit deficits. This would lead to

ever-rising public debt. However, the government has already started implementing the first phase of its medium-term fiscal strategy to reduce deficits and public debt. 
Table A1. Iceland: External Debt Sustainability Framework Current Baseline, 2004-14

(In percent of GDP, unless otherwise indicated)

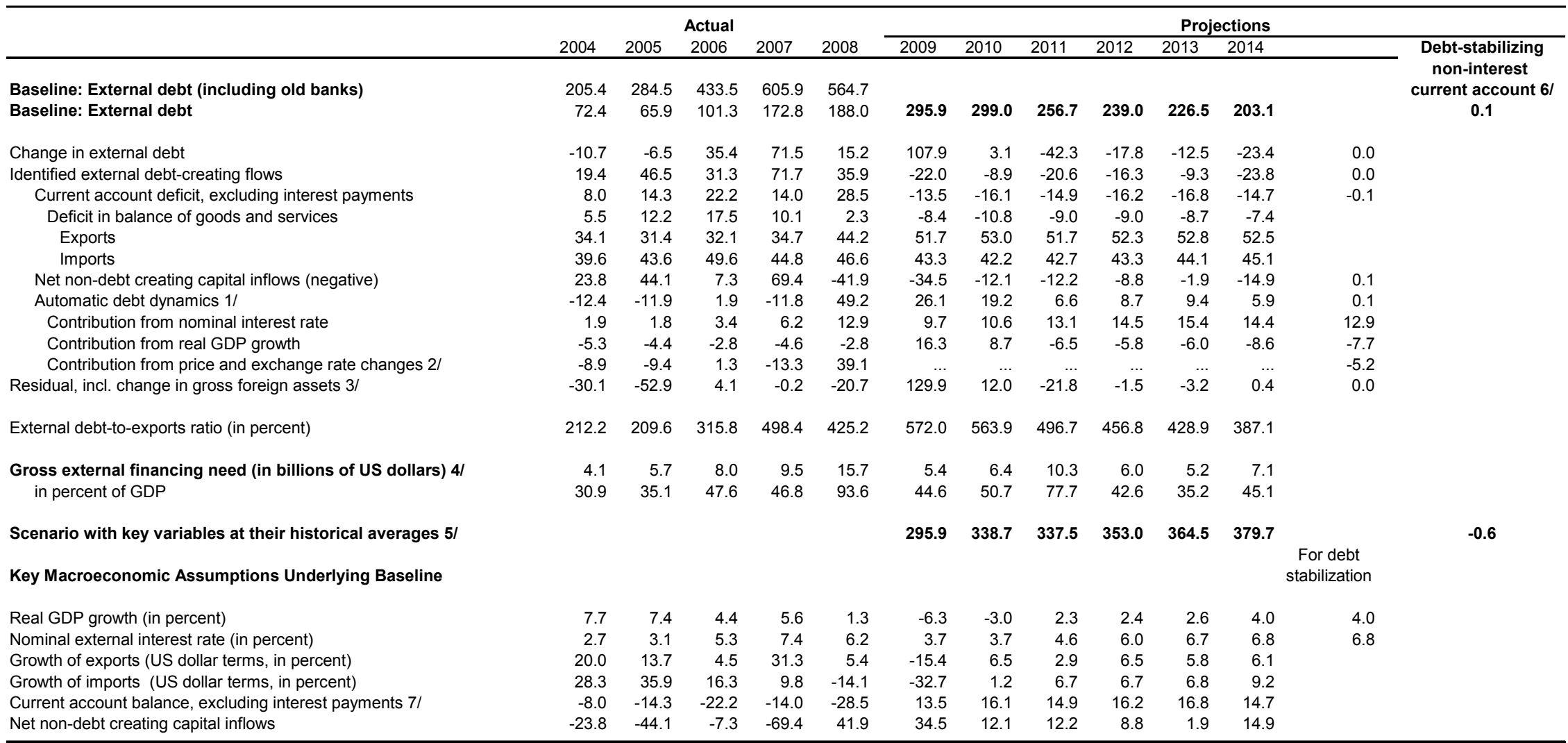

$1 /$ Derived as $[r-g-r(1+g)+$ ea $(1+r)] /(1+g+r+g r)$ times previous period debt stock, with $r=$ nominal effective interest rate on external debt; $r=$ change in domestic GDP deflator in US dollar terms, $g=$ real GDP growth rate,

$=$ nominal appreciation (increase in dollar value of domestic currency), and $a=$ share of domestic-currency denominated debt in total external deb.

$2 /$ The contribution from price and exchange rate changes is defined as $[-r(1+g)+e a(1+r)](1+g+r+g r)$ times previous period debt stock. rincreases with an appreciating domestic currency $(e>0)$ and rising inflation $(G D P$ deflator)

$3 /$ Projections also reflect the impact of price and exchange rate changes, inflows of extraordinary financing (and Fund repurchases).

4/ Defined as current account deficit, plus amortization on medium- and long-term debt, plus short-term debt at end of previous period.

5/ The key variables include real GDP growth; nominal interest rate; dollar deflator growth; and both non-interest current account and non-debt inflows in percent of GDP.

6/ Long-run, constant balance that stabilizes the debt ratio assuming that key variables (real GDP growth, nominal interest rate, dollar deflator growth, and non-debt inflows in percent of GDP) remain at their levels

of the last projection year. This estimate excludes old bank-related asset recovery in 2014, and large one-off projected liquidation of assets abroad, to service lumpy debt payment.

7/ Historical debt and interest data exclude old bank data (based on staff and Central Bank estimates). 
Figure A1. Iceland: External Debt: Current Baseline Projection 1/2/ (in percent of GDP)

Baseline and historical scenarios

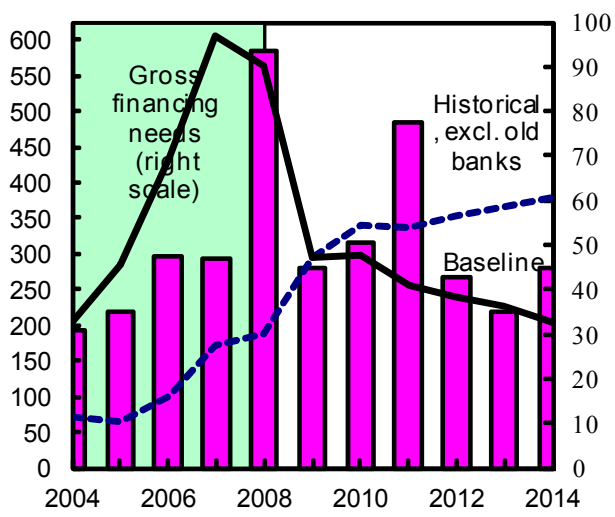

Interest rate shock

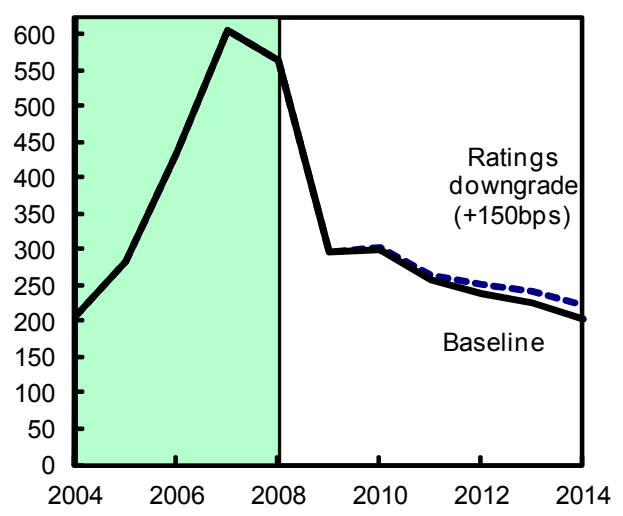

Additionaldebt 4/

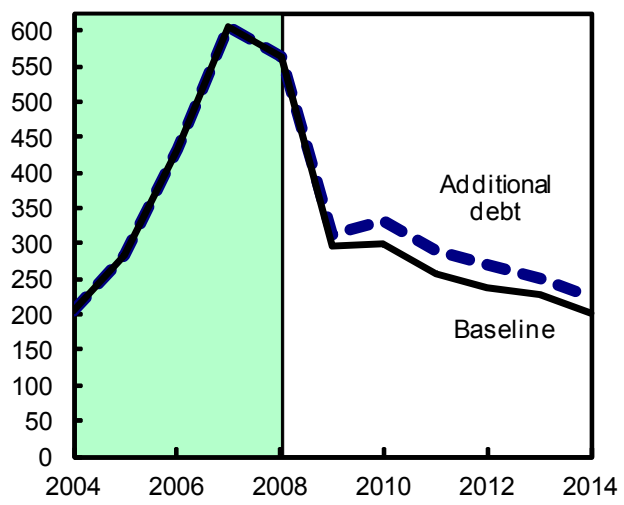

Lower a sset recovery $3 /$

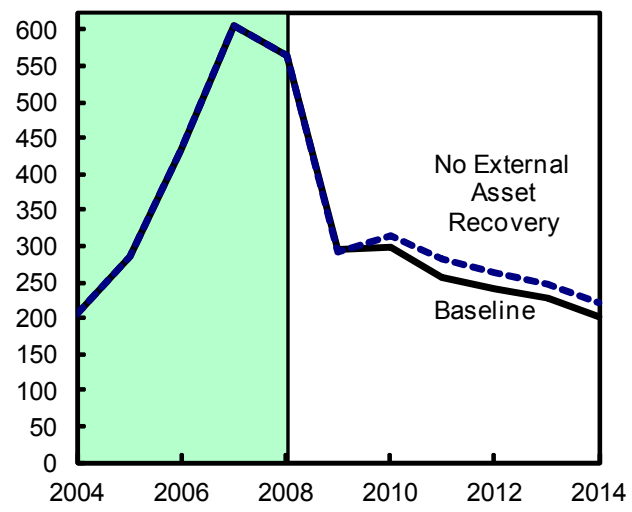

Non-interest current account shock (in percent of GDP)

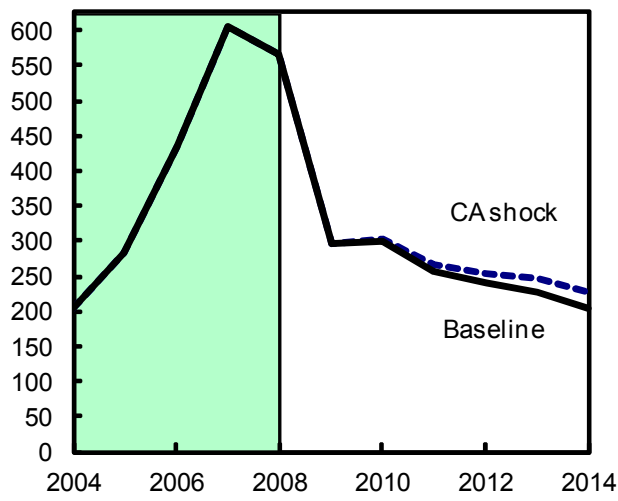

Realdepreciation shock 5/

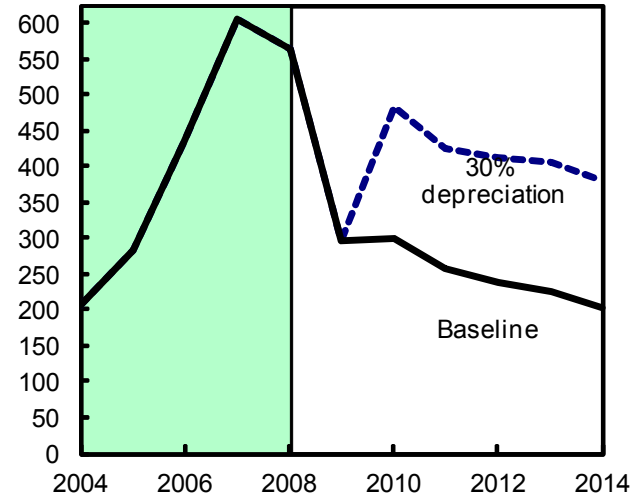

Sources: International Monetary Fund, Country desk data, and staff estimates.

1 / Shad ed areas represent preliminary actual data including old banks unless otherwise indicated. In dividual shocks are permanent one-half standard deviation shocks.

$2 /$ GDP is converted into $\$$ at average exchange rates.

$3 /$ Lower asset recovery scenario reduces the expected extemal asset recovery to fifty percent of the baseline projection for Old Lan dsbanki.

4/ Assumes 20 percent of GDP ( $\$ 2.4 \mathrm{bn})$ increase in external debt.

$5 /$ One-time real depreciation of 30 percent occurs in 2010. 
Table A2. Iceland: Public Sector Debt Sustainability Framework, 2004-14

(In percent of GDP, unless otherwise indicated)

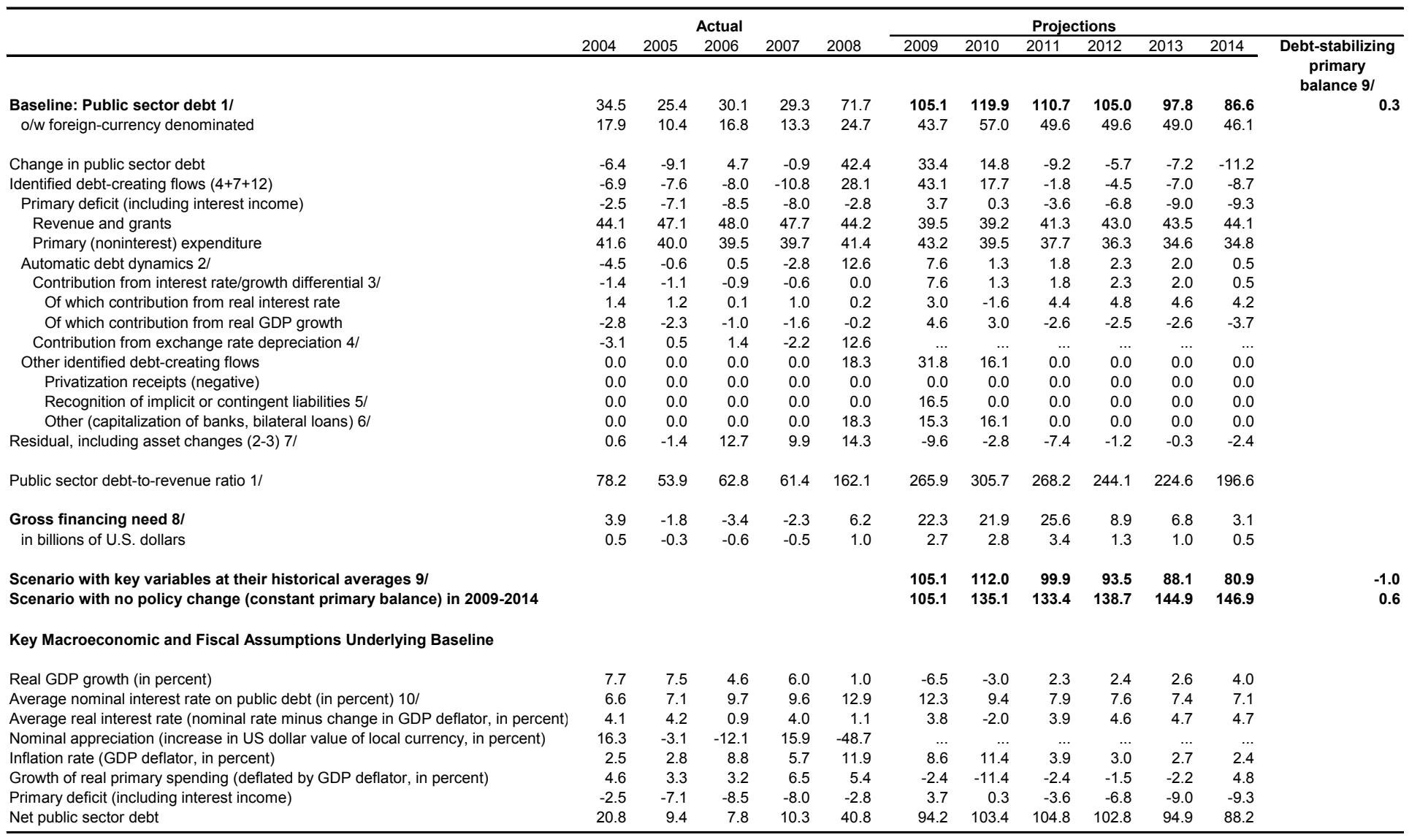

$1 /$ General government gross debt (including bilateral loans to the central government to support central bank reserves; excludes IMF loans).

Also includes the estimated impact of the guarantee on UK/Dutch IceSave loans, net of asset recovery. It estimates, under given assumptions for asset recovery and on a cash flow basis,

the residual obligation for the government and growth thereof due to accruing interest.

$2 /$ Derived as $(r-\pi(1+g)$

denominated debt, and $\varepsilon=$ tominal exchange rate depreciation (measured by increase in local currency value of U.S. dollar).

$3 /$ The real interest rate contibution is derived from the denominator in footnote $2 / \mathrm{as} s-\pi(1+\mathrm{g})$ and the real growth contribution as $-\mathrm{g}$.

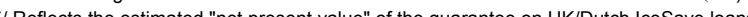

(6/nals

For projoctions, this in

10/ Defined as general government deficit, plus amortization of medium and long-term general government debt, plus short-term debt at end of previous period.

(CInternational Monetary Fund. Not for Redistribution 
Figure A2. Iceland: Public Debt Sustainability under Current Projection 1/ (Public debt in percent of GDP)

Baseline and historical scenarios

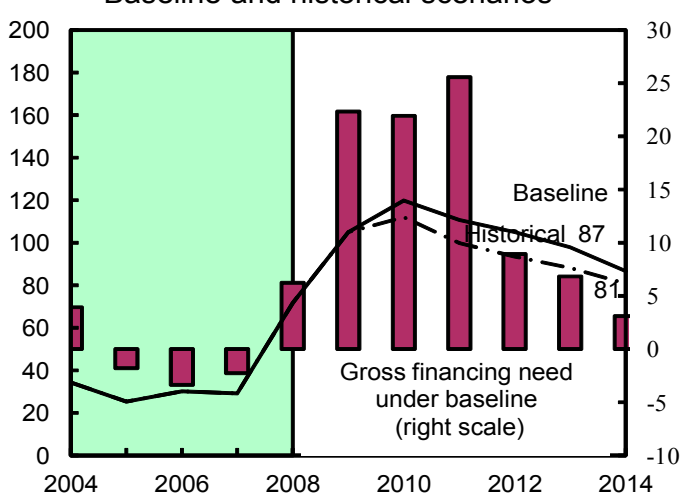

Growth shock (in percent per year)

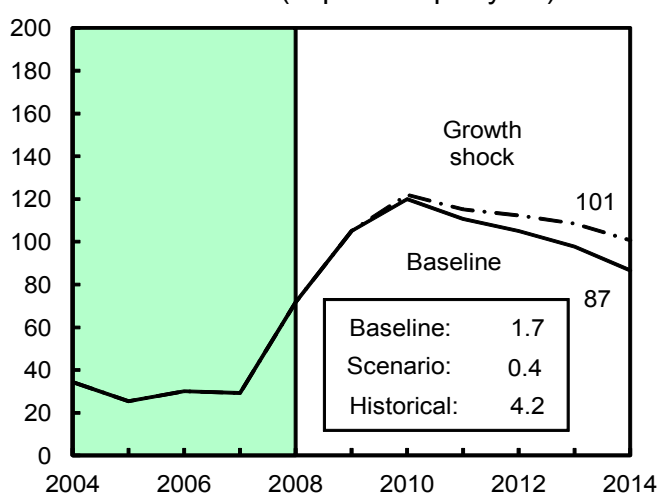

Combined shock 2/

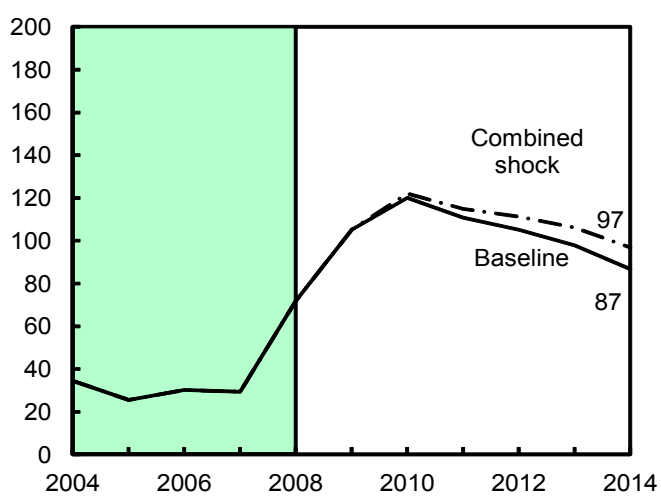

Interest rate shock (in percent)

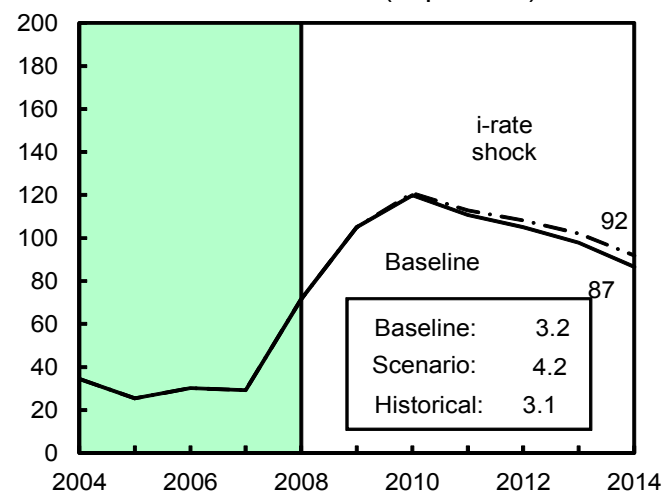

Primary balance shock (in percent of GDP) and no policy change scenario (constant primary balance)

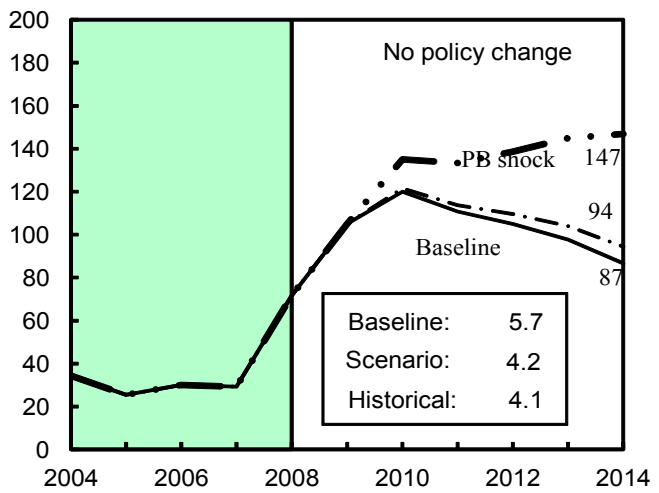

Real depreciation and contingent liabilities shocks 3/

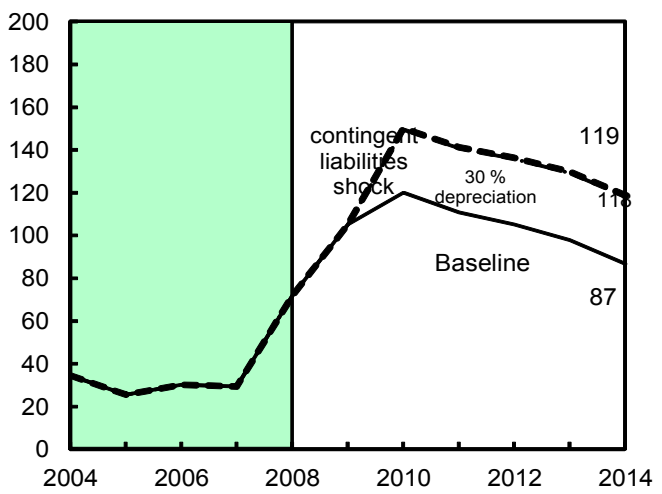

Sources: International Monetary Fund, country desk data, and staff estimates.

1/ Shaded areas represent actual data. Individual shocks are permanent one-half standard deviation shocks. Figures in the boxes represent average projections for the respective variables in the baseline and scenario being presented. Ten-year historical average for the variable is also shown.

2/ Permanent $1 / 4$ standard deviation shocks applied to real interest rate, growth rate, and primary balance.

$3 /$ One-time real depreciation of 30 percent or 30 percent of GDP shock to contingent liabilities occur in 2009, with real depreciation defined as nominal depreciation (measured by percentage fall in dollar value of local currency) minus domestic inflation (based on GDP deflator). 


\section{ATTACHMENT I. LETTER OF INTENT}

Reykjavik, April 7, 2010

Mr. Dominique Strauss-Kahn

Managing Director

International Monetary Fund

Washington D.C., 20431

U.S.A.

Dear Mr. Strauss-Kahn:

1. Our economic program, supported by a Stand-By Arrangement from the Fund, is delivering on its objectives. Progress towards fiscal sustainability is reflected in passage of a 2010 budget embodying significant adjustment, and in the approval of a rigorous public debt management plan. A key first step towards full restructuring of the financial sectorrecapitalization of the banking system - is now all but complete. And the krona has been stable. While Iceland's economy faces a difficult period of adjustment, our policy successes to date have helped make the recession less severe than expected. With continued policy implementation Iceland's economic recovery should commence during 2010, setting the stage for declines in high public and external debt levels over time.

2. Our policy implementation is broadly on track. All performance criteria, including end-December targets, have been met. Benchmarks concerning approval of a public debt management plan, recapitalization of Landsbanki, and submission to parliament of legislation covering supervisory reforms have been met, albeit with delay in two cases. The benchmark on recapitalizing the savings banks has not been observed, but the work in this area is now almost complete. The status of all program measures is summarized in Tables 1-2.

\section{On this basis, we request completion of the second review under the Stand-By}

Arrangement. In light of the delay in the second review, we request that the arrangement be extended to August 31, 2011 and purchases rephased. The third review would now be available on or after July 15, 2010, with quarterly reviews thereafter (beginning in the fourth quarter of 2010). Moreover, as set out in Table 1, we request that ceilings and floors for the quantitative performance criteria under the arrangement be established for May 31, 2010, and September 30, 2010, and that indicative targets be set for December 31, 2010. As detailed below, we also propose 5 new structural benchmarks against which to measure progress towards key fiscal and financial sector objectives for the next 12 months (Table 2).

4. We believe that the policies set forth in this and previous letters are adequate to achieve the objectives of our program. We stand ready to take any further measures that may become appropriate for this purpose. We will consult with the Fund on the adoption of any such measures and in advance of revisions to the policies contained in this letter, in accordance with the Fund's policies on such consultation. 


\section{The outlook}

5. We expect the economy to turn the corner in $\mathbf{2 0 1 0}$ and begin a gradual recovery:

- Quarterly growth should turn positive by the second half of 2010, on the back of strong export performance, but we expect the recovery to be gradual over the medium-term. Risks to growth remain significant, mainly from weaker than projected consumption and investment as the economy de-leverages, and from uncertainties surrounding the timing of investments in the energy intensive sector. Upside is also possible: strong competitiveness may lead to a stronger-than-projected response of exports, and there is ample upside potential through higher foreign direct investment.

- Headline inflation should subside to below 5 percent by end-2010 and fall to the 3-4 percent range in 2011. Stability of the krona and significant slack in the economy will reduce price pressures next year. Risks to the inflation outlook emanate from possible second-round effects of exchange rate fluctuations, and wage increases in export sectors, and potentially persistent inflation expectations. If the krona strengthens more than currently forecast, we may see faster disinflation. To help contain risks, the Government remains committed to a Stability Pact with its social partners.

6. We expect debt levels to peak at high levels in 2010, and then recede:

- $\quad$ Public debt is climbing at a slower rate than expected. We have been able to partly finance our deficit by selling some of the financial assets acquired during the crisis, while there had been less need than anticipated for government resources in recapitalizing the banking system, reflecting creditor acquisition of the government equity share in Islandsbanki and Arion Bank. Public debt is on a robust downward path, and with the further recovery and sale of assets acquired during the financial crisis, and careful management of our debt refinancing needs (as outlined below), we believe that by 2014 it can be reduced to below 90 percent of GDP in gross terms (including residual Icesaverelated debt), or below 65 percent of GDP after netting out government deposits.

- For external debt, a clearer picture is emerging, and the overall level is expected to remain well below the pre-crisis peak. The total overall gross debt level is now projected to peak at about 300 percent of GDP, compared with over 600 percent of GDP pre-crisis. Private debt is now estimated to be higher because it has become apparent that old banks will recover some assets from domestic sources. Since these new private debts mainly have a medium to long term maturity, and capital controls are now in place, we do not expect them to exert near-term pressure on the balance of payments. In the medium-term, any over-indebted corporations will have to address their debt overhang, assisted by the framework for private sector debt restructuring. Overall, the gross external debt is expected to fall to under 250 percent of GDP by 2014 . 
7. Underpinning these outcomes is the originally envisioned program financing, and a modified policy framework. Our external financing needs continue to be satisfied by a combination of IMF funds, and loans from the Nordic countries and Poland. Slow progress in our Icesave discussions with the U.K. and Netherlands may delay realization of some of the programmed bilateral financing, but as discussed at the end of the letter we expect these negotiations to reach a conclusion soon. A current account surplus, in the context of capital controls, can help keep the program fully financed in the interim. Our key objectives - currency stability, fiscal sustainability and financial sector restructuring - are also unchanged and remain crucial for securing a durable recovery and reducing risks. However, we are introducing some policy modifications to support economic activity in the near term, as discussed in what follows.

\section{Fiscal Policy}

8. We have adjusted the fiscal stance to help support the recovery. Lower public debt and an improved outlook for public debt sustainability have paved the way for a more supportive stance. Thus the general government primary deficit adjustment, on a national accounts cash basis, will be $4 \frac{1}{4}$ instead of 5 $1 / 2$ percent of GDP in 2010 (which will deliver a general government primary deficit level of $23 / 4$ percent of GDP). We expect local governments, in aggregate, to maintain broadly the same primary balance in 2010 as in 2009, and their budget plans are in line with this. Social security funds should show a mild deterioration in their balance. To achieve our target, we thus plan a central government primary adjustment of 4.4 percent of GDP (to achieve a primary deficit level of -2.4 percent of GDP). The central government budget, embodying the measures necessary to achieve this target, was passed by parliament in December (meeting a prior action for the review):

- $\quad$ Revenue measures will help raise the primary revenue ratio by 1.2 percent of GDP. Without these measures, cyclical and other factors would have led to a decline in the revenue ratio. We expect the changes to improve the fairness of the tax system:

Underlying measures amount to 2.1 percent of GDP and include: (i) introduction of a three-bracket PIT system with an increased tax-free allowance and an increase of the capital income tax; (ii) an increase in the standard VAT rate; (iii) a new tax on wealthy individuals; (iv) new environmental and carbon taxes; and (v) increases in excises, social security contributions and fees. To facilitate stronger administration, we have also amended the income tax law to address issues of tax circumvention and arbitrage.

Temporary measures amount to a further 0.4 percent of GDP. These include revenues from extending the possibility to withdraw savings from individual supplementary pension savings accounts, and from prepayment of corporate taxes by high-energy users. 
- $\quad$ Expenditure measures will help reduce the primary spending ratio by 3.2 percent of GDP. They include general cuts in current expenditure and wages formulated at the agency level under the guidance of the Ministry of Finance; cuts in transfer payments, including from improved means-testing of social benefits and efficiency gains in the health system; cuts in investment and maintenance projects to pre-boom levels; non-indexation of wages and benefits; and reductions in discretionary spending items. These changes do not affect the key features of our social safety net, and indeed the budget allocates additional resources for vulnerable groups (e.g. for enhanced educational and work opportunities for the young).

- We will use any revenue over performance and under spending in 2010 to accelerate our fiscal adjustment, just as we did in 2009.

9. The Ministry of Finance has approved a public debt management strategy (a prior action for this review). The aim is to support the fiscal adjustment path by smoothing the financing of the deficit and refinancing of debt coming due, and by containing risks from contingent liabilities. The strategy emphasizes: (i) diversification across instruments and the investor base; (ii) prudent management of rollover risks; (iii) the sale of financial assets acquired during the crisis; (iv) a stronger framework for managing contingent liabilities; and (v) strengthened institutional arrangements.

10. We will continue to strengthen the fiscal framework during 2010, with a focus on fiscal-federal relations. We expect the new local government framework to comprise: (i) a fiscal rule; (ii) clear restrictions on municipal borrowing; (iii) robust mechanisms for dealing with volatility in local revenues; (iv) enhanced in-year surveillance of local government fiscal developments; (v) stronger national-local dialogue on fiscal objective-setting and budget planning; (vi) a range of sanctions for non-compliance. The preparatory work will be completed by end-August, and budgets for 2011 will be prepared in line with the new framework. We intend to enact these changes into law by end-2010, and propose this to be a new program structural benchmark.

\section{Monetary Policy and Capital Controls}

\section{Monetary policy will continue to be guided by the interim objective of currency} stability. The potential for currency depreciation, inflation pass-through, and further balance sheet stress call for caution concerning changes in the policy stance. To the extent the exchange rate strengthens, we will need to balance the benefits that can be delivered by accumulating reserves against those to be derived through interest rate reductions. Uncertainty about the precise timing of external financing argues for some reserve accumulation at an earlier stage than previously envisaged, done in a manner to preserve the gradual recovery of the króna. The scope for reducing interest rates will accordingly be more limited until the timing becomes clear. 


\section{To enhance the effectiveness of policy, the MPC has realigned the CBI's interest} rates within a narrower corridor. The width of the corridor has been reduced to $300 \mathrm{bps}$, and the central bank CD rate and the 7-day repo lending rate have been positioned close to the center of it. One or the other will be used depending on the CBI's need to withdraw or inject liquidity. To further enhance liquidity management, the CBI has started pre-announcing targeted weekly volumes (set at a level to remove the estimated liquidity surplus at a given interest rate target), and accepting all bids up to this targeted volume.

13. We have adjusted our capital controls regime, to enhance its effectiveness. At endOctober, we took the first step in our liberalization strategy by lifting controls on new investment (the initial inflow and proceeds from new investments in foreign currency became freely transferable).However, the conditions are not yet in place to begin liberalizing capital outflows, and in particular greater certainty about the timing of external financing will first be required. To enhance the effectiveness of administration in the near term, we have introduced revised rules, which include limitations on cross-border movements of krona and fewer exemptions. We have backed this up with increased resources for monitoring, and by enforcement actions. These steps are already showing results: the onshore rate has appreciated even while intervention has ceased. Looking forward, we will ensure adequate resources in monitoring and enforcement of the controls, and data collection, and stand ready to revise and extend the foreign exchange act and rules as necessary to ensure their effectiveness.

\section{Financial sector policies}

14. Recapitalization of the banking sector will soon be complete. This will mark a necessary first step towards a durable renewal of lending, and set the stage for more complete operational restructuring during 2010:

- New Landsbanki has been recapitalized to 12 percent of tier I capital to risk-weighted assets (a prior action for the review). The government capital injection, ISK 122 billion, was made based on the bank's December 2008 audited financial statements. The compensation agreed with Old Landsbanki reflected a valuation methodology that the FME has accepted as consistent with industry standards. And the compensation package comprised a fixed instrument, a contingent bond and 19 percent of bank shares. This completes the recapitalization of the commercial banks.

- We have made substantial progress towards recapitalizing savings banks and, while we were not able to observe the end-November structural benchmark to this end, we will soon fully complete the process. An agreement has been reached with eight smaller savings banks to be confirmed in April by their boards and the FME. Three will be recapitalized by their owners, while the remaining five will be recapitalized up to 16 percent of their risk weighted assets. Negotiations with the creditors of the two largest savings banks - Sparisjóðurinn í Keflavik and Byr - on necessary haircuts and write downs of equity by owners have been completed and are now proceeding to 
documentation. These institutions will be recapitalized up to 16 percent of their risk weighted assets (tier 1 capital to 12 percent and tier 2 capital to 4 percent). If necessary, public funds will be used to the limits defined in the Emergency Law, but only after all existing losses are allocated to their owners and creditors, managers and directors that are deemed to be "non fit" and "not proper" are removed, and a strategy to strengthen their liquidity position is put in place. We propose the recapitalization of Sparisjóðurinn í Keflavik and Byr as a new program structural benchmark for end-May 2010. The total fiscal cost of addressing the recapitalization of the savings bank sector is not expected to exceed $1 \frac{1}{2}$ percent of GDP.

15. The remainder of the financial system will be put onto a stronger footing. We will take several steps to further enhance the medium-term viability of the non bank financial institutions and the Housing Financing Fund (HFF):

- $\quad$ By end-June 2010 the non bank financial institutions and HFF will present business plans to the FME (using macro assumptions in the Fund-supported program and the premises considered by the new banks in the preparation of their business plans) demonstrating their capacity to remain solvent and generate liquidity to honor debt coming due over the next three years, without government support. The FME will complete the review of the consistency and credibility of these reports and require rehabilitation and/or recapitalization measures where needed by end-August 2010. We propose this as a new program structural benchmark. We remain committed to no absorption of losses and no public assets will be used to rehabilitate the non bank financial institutions.

- We will ensure that the HFF is subject to prudential rules similar to those faced by other financial intermediaries, with an appropriate phase in for increases in capital.

16. A bill has been submitted to parliament to strengthen our regulatory and supervisory practices (meeting an end-December structural benchmark):

- The draft legislation to address deficiencies in the bank regulatory framework is expected to be passed by end-June. The legislation mandates improved risk management systems and governance in banks (including via stronger rules on remuneration systems and severance agreements); strengthens provisions on large exposures and connected and related party lending; enhances fit and proper requirements for major shareholders; grants discretionary powers to the FME to act on key fronts (including concerning credit limits for institutions, and the eligibility of potential investors); permits the creation of a credit registry at the FME; boosts the quality of bank equity; and strengthens provisions covering both internal and external bank audit.

- We have also introduced a draft bill of law modifying the deposit guarantee regime. At the present time, we remain committed to protect depositors in full, but when financial stability is secured we will plan for the gradual lifting of this blanket guarantee. Only 
when we reach this point, will the coverage be gradually reduced to the EUR 50,000 defined in the bill. The framework will specify coverage in line with EU legislation, ensure quick repayment on a gross basis, and gradually introduce higher risk based insurance premia.

17. We will take further actions to strengthen regulation and supervision during 201011:

- $\quad$ On the basis of the revised legal framework, by end-September we intend to amend key prudential rules (regarding connected parties, large exposures and the use by banks of the consolidated information on borrowers in the FME's new credit registry). We also will ensure that commercial banks have adopted measures to address risk management and the governance issues identified in FME comments on their business plans. Finally, to facilitate prudential monitoring, we intend to introduce temporary requirements for commercial and savings banks to submit audited financial statements semi-annually (instead of annually) for the next two years.

- We intend to take stock of the implementation of recommended changes in our supervisory regime, and assess whether there is any need for further strengthening. We will complete an assessment of compliance with the revised Basel Core Principles and formulate a strategic plan to address identified weaknesses. The assessment and plan, which will be published by end-March 2011, will be led by independent and internationally-recognized assessors and conducted on the basis of the Core Principles Methodology. We propose this to be a new program structural benchmark.

\section{Private sector debt restructuring}

18. The tools are being put into place to accelerate private sector debt restructuring. This should place viable firms and households on a sounder footing and support private sector demand:

- A comprehensive framework is being established for household debt restructuring:

- Information. All households have access to the Debt Advisory Services, which provides information and advice to individuals on restructuring options.

- Automatic measures. Households holding CPI-indexed mortgages are automatically placed into a generalized payment smoothing program to provide debt service relief for mortgages (but can opt out). A similar scheme exists for fx-denominated mortgages and auto loans, albeit on an opt-in basis.

- Voluntary workouts. All households can also seek a voluntary agreement with their lenders on a workout. Generalized guidelines have established eligibility and have 
specified criteria for debt write downs. Based on these guidelines, the banks and HFF have established their own frameworks for voluntary workouts.

- Court-assisted processes. If such measures prove insufficient, households have access to a court-supervised process covering residential mortgages, in which the court will decide a new payment mitigation scheme based on repayment capacity.

- To ensure that the framework functions smoothly, we intend to (i) provide debtors better access to information, advice, and mediation mechanisms in the context of voluntary workouts; (ii) extend eligibility to households and individuals not now covered by the schemes; and (iii) create incentives for financial institutions and debtors to expedite voluntary restructuring agreements. We propose that passage of legislation to strengthen the framework along these dimensions be a structural benchmark for end-June 2010. We emphasize that with this refined framework in place, there will be no further extensions of the moratorium on foreclosures, and we will allow it to expire on schedule at end-October 2010.

- The framework is in line with the financial capacity of banks and financial institutions to engage in workouts. We will take the necessary measures to ensure the system has enough administrative capacity to process workouts. We do not expect any fiscal costs, but if any do emerge, they will have to fit within the agreed fiscal envelope.

- We have introduced a framework to support voluntary corporate debt restructuring. By law financial institutions are required to submit internal guidelines for debt restructuring to the FME for approval. The FME has evaluated and approved these guidelines and the Competition Authority is expected to sign off by end-April. These guidelines apply to businesses of all sizes, but banks may introduce more expeditious procedures to restructure smaller corporations as needed. The guidelines include: criteria under which loan terms can be altered, criteria to evaluate a debtor's assets and liabilities and a debtor's ability to service debt based on expected future income and cash-flow, as well as other objective criteria which may be used to evaluate the debtor, company management and owners. A special committee will monitor and report on whether debt restructuring guidelines adopted by financial institutions are being applied as intended and with an overall emphasis on transparency and fairness.

- Incentives are being introduced for banks to accelerate corporate debt restructuring. We have submitted a bill amending the Act on Financial Undertakings, which ensures that unrestructured loans are reflected in banks' books and provisions on a timely basis. The FME will also require more frequent independent auditing of the valuation of loan collateral, undertake enhanced onsite examination, and require incorporation of $\mathrm{fx}$ loans to unhedged borrowers (that are in the process of being converted into ISK) into the computation of market risk, by end-2011. 
- $\quad$ The government will also take steps to facilitate restructuring (without absorbing any private sector losses). In particular, we will propose measures to ensure that the tax treatment of debt write-offs does not complicate debt restructuring. The government has also offered extended installment schemes to viable debtors; and, for other debtors, will review collection procedures to ensure that they maximize government recovery and allow for timely decisions.

19. The insolvency regime will be refined. This is necessary to support debt restructuring, and to address non-viable borrowers:

- We have submitted to Parliament proposals to amend the insolvency regime. We expect the amendments to be passed by end-June. The amendments will aim in particular to (i) simplify and expedite in-court proceedings for reaching restructuring agreements between viable debtors and a qualified majority of creditors, and for liquidating unviable debtors; (ii) facilitate cross-border insolvency proceedings by allowing a debtor or foreign bankruptcy trustee to seek assistance from Icelandic courts even in the absence of an international treaty; and (iii) ensure protection of secured creditors' claims. Finally, we will conduct an assessment to determine whether to implement a system of "prepackaged debt restructuring plans" to enable viable debtors to reach out-of-court restructuring agreements with a qualified majority of creditors. This assessment will be concluded by end-June 2010, and if the conclusion is that the implementation of such a system is advisable, a proposal for its establishment will be submitted to Parliament by end-October 2010.

- We will also expand the capacity of the institutional framework to process cases by increasing the number of judges and assistant judges by 5 each. We have also appointed a working group to assess whether changes can be made to criminal procedural law to lessen the strain on the District Courts and the Supreme Court.

\section{External Financing}

20. Our ability to fully implement the program described above is dependent on access to the external financing committed under the program. We firmly expect to be able to meet the preconditions set by some of our bilateral partners to access this finance. In this context, we wish to reaffirm that Iceland will honor its obligations in regard to the insured retail depositors of the intervened banks. Iceland has already affirmed in its Letter of Intent dated 15 November 2008 that it is willing to ensure that the United Kingdom and the Netherlands will be reimbursed in respect of deposits of Landsbanki branches in those two countries (up to the Euro 20,887 minimum provided for under Icelandic Law and the EU Deposit Guarantee Directive 90/19/EC). Iceland has also given an assurance that the United Kingdom and the Netherlands will receive the reasonable time value of money, provided that comprehensive agreements are reached. Iceland remains ready to conclude at the earliest convenience the 
negotiations with the Governments of the United Kingdom and the Netherlands regarding a legal and financial settlement of this matter.

21. Progress in covering our financing need will continue to be assessed during quarterly program reviews. In the event of further delays to financing, we stand ready to consult with the Fund on any additional measures that would prove necessary to meet program objectives (consistent with our undertaking in paragraph 4 above).

Very truly yours,

$/ \mathrm{s} /$

Jóhanna Sigurðardóttir

Prime Minister

$/ \mathrm{s} /$

Gylfi Magnússon

Minister of Economic Affairs
$/ \mathrm{s} /$

Steingrímur J. Sigfússon

Minister of Finance

$/ \mathrm{s} /$

Már Guðmundsson

Governor of the Central Bank of Iceland 
Table 1. Iceland Quantitative Performance Criteria and Indicative Targets

\begin{tabular}{|c|c|c|c|c|c|c|c|}
\hline & \multicolumn{6}{|c|}{ Performance Criteria } & \multirow{2}{*}{$\begin{array}{c}\text { Indicative Target } \\
\text { Dec } 10 \\
\text { Ceiling/Floor 2/ }\end{array}$} \\
\hline & $\begin{array}{l}\text { Oct } 09 \\
\text { Prog. 1/ }\end{array}$ & $\begin{array}{l}\text { Oct } 09 \\
\text { Actual } \\
1 /\end{array}$ & $\begin{array}{l}\text { Dec } 09 \\
\text { Prog. } 1 /\end{array}$ & $\begin{array}{c}\text { Dec } 09 \\
\text { Actual } \\
1 /\end{array}$ & $\begin{array}{l}\text { May } 10 \\
\text { Ceiling/Floor 2/ }\end{array}$ & $\begin{array}{l}\text { Sep } 10 \\
\text { Ceiling/Floor 2/ }\end{array}$ & \\
\hline & \multicolumn{7}{|c|}{ (In billions of Króa) } \\
\hline 1. Floor on the change in the central government net financial balance $3 /$ & -175 & -139.5 & -200 & -166.7 & -55 & -120 & -150 \\
\hline $\begin{array}{l}\text { 2. Ceiling on the change in net domestic assets of the Central Bank of Iceland } \\
4 /\end{array}$ & 20 & 34 & 42.6 & 30.3 & 65 & 65 & 65 \\
\hline \multirow[t]{2}{*}{$\begin{array}{l}\text { 3. Ceiling on the change in the domestic claims of the Central Bank of Iceland } \\
\text { to the central government (Indicative targets) }\end{array}$} & 70 & 8.6 & 70 & 13.8 & 80 & 80 & 80 \\
\hline & \multicolumn{7}{|c|}{ (In millions of U.S. dollars) } \\
\hline $\begin{array}{l}\text { 5. Floor on the change in net international reserves of the Central Bank of } \\
\text { Iceland } 5 /\end{array}$ & -425 & -278 & -475 & -319 & -325 & -350 & -425 \\
\hline $\begin{array}{l}\text { 6. Ceiling on the level of contracting or guaranteeing of new medium and long } \\
\text { term external debt by central government } 6 /\end{array}$ & 3500 & 54.5 & 3500 & 486.6 & 2500 & 2500 & 2500 \\
\hline 7. Ceiling on the stock of central government short-term external debt $7 /$ & 1400 & 0 & 1400 & 0 & 750 & 750 & 750 \\
\hline $\begin{array}{l}\text { 8. Ceiling on the accumulation of new external payments arrears on external } \\
\text { debt contracted or guaranteed by central government from multilateral or } \\
\text { bilateral official creditors } 7 /\end{array}$ & 0 & 0 & 0 & 0 & 0 & 0 & 0 \\
\hline
\end{tabular}

1/ Cumulatively from January 1, 2009 (unless otherwise indicated).

2/ Cumulatively from January 1, 2010 (unless otherwise indicated).

$3 /$ The net financial balance excludes the capital injection cost of bank and central bank recapitalization and excludes the increase in debt from guaranteeing the repayment of depositors in foreign branches of Icelandic banks.

4/ Excluding changes due to central bank recapitalization bond.

$5 /(-)$ indicates decrease. NIR is the difference of gross foreign assets and foreign liabilities (including all foreign currency deposits and other liabilities of financial institutions and the general government at the CBI, as specified in the TMU. NIR adjuster is specified in the TMU.

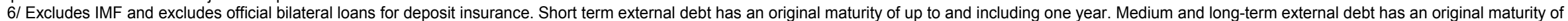
more than one year.

7/ Applies on a continuous basis. 
Table 2. Iceland: Prior Actions and Structural Conditionality

\begin{tabular}{|c|c|}
\hline Structural Conditionality & Status \\
\hline $\begin{array}{l}\text { Prior actions } \\
\text { - A capital injection into New Landsbankinn, using tradable government bonds issued on market } \\
\text { terms, to raise the capital adequacy ratio to at least } 12 \text { percent. } \\
\text { - Approval by the Ministry of Finance of a medium-term public debt management plan. } \\
\text { - Passage of the } 2010 \text { central government budget consistent with program targets. }\end{array}$ & $\begin{array}{l}\text { Done } \\
\text { Done } \\
\text { Done }\end{array}$ \\
\hline $\begin{array}{l}\text { Structural Benchmarks } \\
\text { - A capital injection into New Landsbankinn, using tradable government bonds issued on market } \\
\text { terms, to raise the capital adequacy ratio to at least } 12 \text { percent. } \\
\text { - Completion of the program of savings bank recapitalization, meeting FME and Ministry of Finance } \\
\text { requirements. } \\
\text { - Approval by the Ministry of Finance of a medium-term public debt management plan. } \\
\text { - Submission to parliament of legislation to address deficiencies in the bank regulatory framework } \\
\text { and supervisory practice. By end-December } 2009.1 /\end{array}$ & $\begin{array}{l}\text { Implemented with delay as prior } \\
\text { action (see above) } \\
\text { Not observed (Reset as structural } \\
\text { benchmark; see below) } \\
\text { Implemented with delay as prior } \\
\text { action (see above) } \\
\text { Done }\end{array}$ \\
\hline 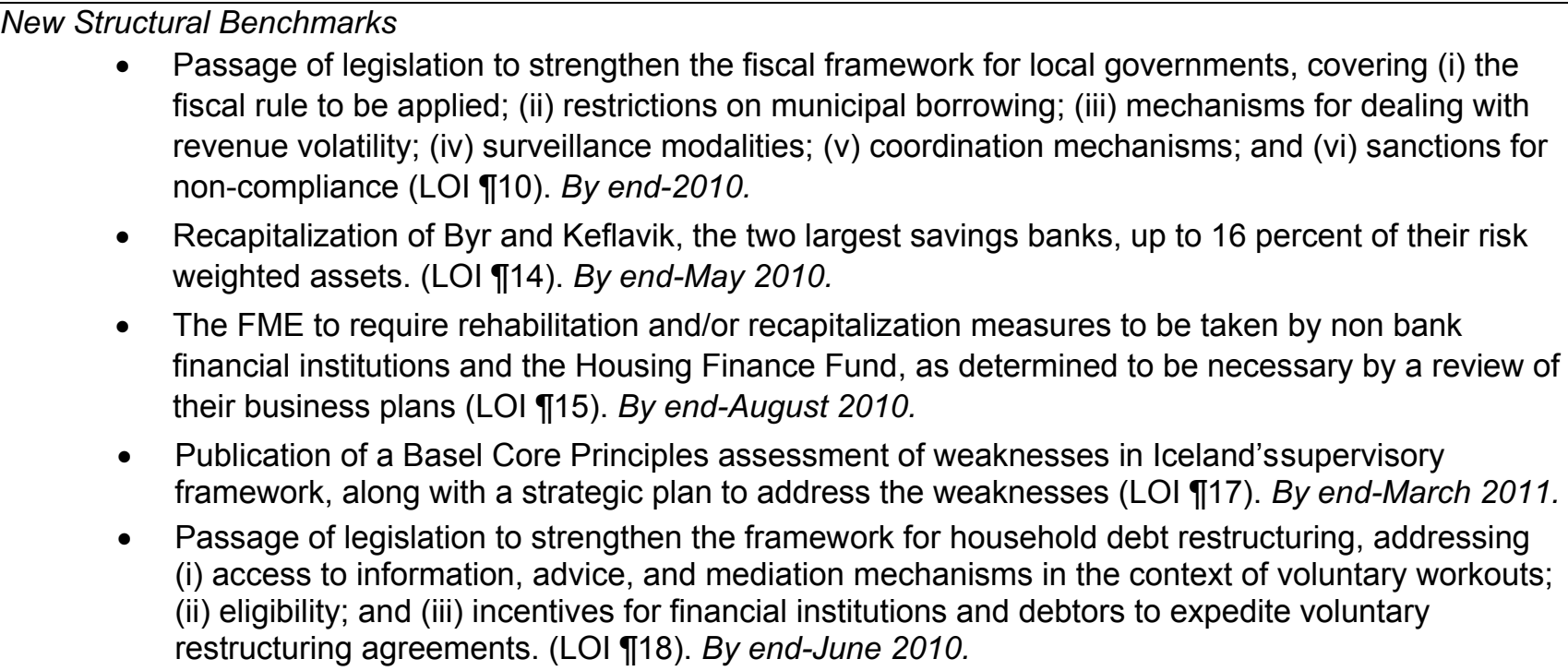 & \\
\hline
\end{tabular}

1/ Corrected from the structural benchmark listed in the table in the First Review Under the Stand-By Arrangement (IMF Country Report No.09/306) to reflect the agreed text in the Letter of Intent. 


\section{Attachment II. Technical Memorandum of Understanding}

1. This memorandum sets out the understandings between the Icelandic authorities and the IMF staff regarding the definitions of quantitative and structural performance criteria, as well as respective reporting requirements for the Stand-By Arrangement (SBA). These performance criteria and indicative targets are reported in Tables 1 and 2.

2. The exchange rate for the purposes of the program is set at 113.9 Icelandic króna per U.S. dollar. The corresponding cross exchange rates are provided in Table 3.

\section{Central Government}

3. Definition: For the purposes of the program, the government includes the central government, which includes government entities of group "A" as defined in the Government Financial Reporting Act No.88/1997.

4. Supporting material: The Ministry of Finance (MoF) will provide to the IMF detailed information on monthly revenues and expenditures both on a cash and accrual basis, domestic and foreign debt redemptions, new domestic and foreign debt issuance, change in the domestic and foreign cash balances of the central government at the central bank of Iceland, all other sources of financing including capital transactions, and arrears of the central government. Data will be provided within 30 days.

\section{Quantitative Performance Criteria, Indicative Targets, and Continuous Performance Criteria: Definitions and Reporting Standards}

\section{A. Floor on the Cumulative Net Financial Balance of the Central Government}

5. Definition: The net financial balance of the central government will be measured from the financing side at current exchange rates, and will be defined after contributions to the government employee's pension fund. The net financial balance will be defined as the negative of the sum of (i) net domestic financing and (ii) net external financing.

- Net domestic financing (NDF) is defined as the change in the stock of the net domestic debt of the central government. Domestic central government debt consists of ISK-denominated debt financed by the banking system (the Central Bank of Iceland (CBI) and commercial banks) and non-bank financial institutions to the central government. It consists of treasury bills, government bonds, promissory notes and other domestic debt instruments issued by the government, including any interest arrears, and loans and advances to the central government by the commercial banks, including any interest arrears. Net domestic central government debt is calculated as the gross debt plus proceeds from the sale of financial assets (including, but not limited to, government, government-backed, or other bonds obtained during the 
central bank recapitalization process, and as a result of failed securities lending) or proceeds from privatization, minus ISK-denominated government deposits with the central bank of Iceland and commercial banks. ISK-denominated government deposits at the central bank of Iceland include the deposits in the treasury current account, government institution current accounts and other time deposits. Domestic debt will be valued at the nominal price for T-notes. For T-bonds and other loans, both of which are indexed, the nominal value of the debt will be adjusted by the consumer price inflation.

- Net external financing is defined as the total of foreign currency denominated financing disbursed to the central government minus the net accumulation of foreign currency deposits at the $\mathrm{CBI}$ and at commercial banks, plus accrued interest from the Icesave-related debt, net change in external arrears, minus amortization paid. Amortization includes all external debt-related payments of principal by the central government. Disbursements and amortization will be valued at the exchange rate at the time of the transaction. Net accumulation of foreign currency deposits is defined as the sum of daily change in the stock of foreign currency deposits at the CBI and at commercial banks in foreign currency, valued at the current daily exchange rate. Accrued interest on Icesave-related debt will be calculated based on the average monthly value of the outstanding stock of Icesave-related debt. The stock of outstanding Icesave-related debt will be calculated as sum of the outstanding loans and the accrued interest from the previous period minus the amount paid out from recovered assets. The stock of Icesave-related debt will be calculated in the currency of the loan agreements (sterling and euro). Accrued interest will be converted to krona at the current (monthly average) exchange rate.

- $\quad$ Adjustments: For the purposes of the program, the net financial balance will exclude any debt issuance for the purposes of bank restructuring and central bank recapitalization. It will; however, include the accrued interest on debts related to central bank and bank recapitalization. Net domestic financing will exclude the retroactive accrued interest on the bank capitalization bonds from October 8, 2008 to October 8, 2009.

\section{Supporting Material:}

- Data on domestic bank and nonbank financing will be provided to the IMF by the Central Bank of Iceland and the Financial Management Department of the MoF within three weeks after the end of the month. This will include data on redemptions of domestic central government liabilities and data on the cash balances in domestic currency of the MoF at the Central Bank of Iceland and in commercial banks.

- Data on net external financing (disbursement, net change in external arrears and amortization) as well as other external borrowing will be provided to the IMF 
monthly by the Financial Management Unit at the MoF within three weeks of the end of each month. Data on the FX cash balances of the MoF at the Central Bank of Iceland and in commercial banks will be reported daily.

\section{B. Floor on the Net International Reserves of the Central Bank of Iceland}

7. Definition: Net international reserves (NIR) of the Central Bank of Iceland (CBI) are defined as the U.S. dollar value of gross foreign assets minus foreign liabilities of the CBI.

- Gross foreign assets are defined consistently with SDDS as readily available claims on nonresidents denominated in foreign convertible currencies. They include the CBI's holdings of monetary gold, SDRs, foreign currency cash, foreign currency securities, deposits abroad, and the country's reserve position at the Fund. Excluded from reserve assets are any assets that are pledged, collateralized, or otherwise encumbered, claims on residents, precious metals other than gold, assets in nonconvertible currencies, and illiquid assets.

- Gross foreign liabilities are defined consistently with SDDS as all FX liabilities to residents and nonresidents, including commitments to sell foreign exchange arising from derivatives, and all credit outstanding and SDR allocation from the Fund. Foreign currency deposits and other liabilities of financial institutions (both active and in the process of winding up) and the general government at the CBI will be included in gross foreign liabilities.

- $\quad$ For program monitoring purposes, the stock of foreign assets and foreign liabilities of the CBI shall be valued at program exchange rates as described on paragraph 2 above. The stock of NIR amounted to $-\$ 425$ million as of October 21, 2008 (at the program exchange rate).

\section{Adjustment mechanism:}

- $\quad$ The NIR floor will be adjusted downward at the program exchange rate by the amount of Nordic disbursements relative to the technical assumption below. For every one dollar of disbursements, NIR floor for each period will be adjusted downward by 0.5 . Nordic disbursements are defined as external disbursements from Denmark, Finland and Sweden to the Government of Iceland and Norway to the CBI.

- $\quad$ For each period, the NIR floor will be adjusted up to an amount specified in the table below. The figures indicate a cap on the cumulative use of NIR. 
NIR adjustment

\begin{tabular}{lcc}
\hline Cumulative flows from End-December 2009 & $\begin{array}{c}\text { In millions of US } \\
\text { dollars at program } \\
\text { exchange rate }\end{array}$ & $\begin{array}{c}\text { Adjustment per one dollar of } \\
\text { additional Nordic } \\
\text { disbursements }\end{array}$ \\
\hline Nordic Disbursements (technical assumption for the adjuster purpose) & \\
End-May 2010 & 0 & -0.50 \\
End-September 2010 & 0 & -0.50 \\
End-December 2010 & 0 & -0.50 \\
NIR cap & & \\
End-May 2010 & -650 & \\
End-September 2010 & -650 & \\
End-December 2010 & -650 & \\
\hline
\end{tabular}

9. Supporting material: Data on net international reserves (both at actual and program exchange rates) and on net foreign financing (balance of payments support loans; cash grants to the consolidated government; amortization (excluding repayments to the IMF); interest payments on external debt by the MoF and the $\mathrm{CBI}$ ) will be provided to the IMF in a table on the CBI's FX flows (which include details of inflows, outflows, and net international reserves) on a monthly basis within two weeks following the end of the month. Flows of net international reserves will be provided on a daily basis.

\section{Ceiling on Net Domestic Assets}

10. Definition: Net domestic assets of the CBI are defined as the sum of net credit to the government, net credit to the private sector and other items net.

- $\quad$ Net credit to the central government is defined in criteria D.

- $\quad$ Net credit to the private sector is defined as the difference between credit to the private sector and liabilities of the private sector to the CBI. Credit to the private sector is defined as the sum of CBI lending to banks and other financial institutions (through its overnight and weekly collateral facilities and any other instruments to which the CBI would extend credit to the private sector) and other assets. Liabilities of the private sector to the $\mathrm{CBI}$ is defined as the sum of current account balances of the banks and other financial institutions at the CBI, central bank CDs in issuance and other liabilities.

- Other items net are defined as the sum of capital contributions, revaluation accounts and retained earnings. Performance against the NDA target will be measured at program exchange rates.

11. Supporting material: The CBI will provide to the IMF with data on net credit to the government and net credit to the private sector. Data on central bank lending to banks and 
other financial institutions through its overnight and weekly collateral facilities, any other instruments to which the CBI would extend credit to the private sector, current account balances of the banks at the CBI, and central bank CDs in issuance, on a daily basis. The CBI will provide the net domestic assets data based on the monthly balance sheets on the monthly basis within two weeks following the end of the month.

\section{Ceiling on Net Credit of the Central Bank of Iceland to the Central Government (Indicative Target)}

12. Definition. Net credit of the CBI to the central government is defined as the difference between $\mathrm{CBI}$ lending to the central government and central government deposits at the $\mathrm{CBI}$ in domestic currency.

- Deposits of the central government at the CBI in domestic currency include the sum of deposits in the treasury current account, government institution current accounts and other time deposits.

- $\quad$ Adjustment. For the purpose of the program, the net credit of the CBI to the central government will exclude any debt issuance for the purposes of recapitalizing the CBI.

- $\quad$ Supporting material: The CBI will provide the IMF with data on central bank lending to the central government and central government deposits at the central bank, on a daily basis with a lag of no more than 10 days.

\section{E. Ceiling on Contracting or Guaranteeing of New Medium and Long Term External Debt by Central Government}

13. Definition: The performance criterion covers public and publicly guaranteed external debt in foreign currency with an original maturity of more than one year. Debt falling within the limit shall be valued in U.S. dollars at the time the contract or guarantee becomes effective.

The term "debt" will be understood to mean a liability created under a contractual arrangement through the provision of value in the form of assets (including currency) or services, and which requires the obligor to make one or more payments in the form of assets (including currency) or services, at some future point(s) in time; these payments will discharge the principal and/or interest liabilities incurred under the contract. Debts can take a number of forms, the primary ones being as follows.

- Loans. That is, advances of money to an obligor by the lender made on the basis of an undertaking that the obligor will repay the funds in the future (including deposits, bonds, debentures, commercial loans and buyers' credits) and temporary exchanges of assets that are equivalent to fully collateralized loans under which the obligor is required to repay the funds, and usually pay interest, by repurchasing the collateral 
from the buyer in the future (such as repurchase agreements and official swap arrangements).

- Suppliers' credits. That is, contracts where the supplier permits the obligor to defer payments until sometime after the date on which the goods are delivered or services are provided.

- Leases. That is, arrangements under which property is provided which the lessee has the right to use for one or more specified period(s) of time that are usually shorter than the total expected service life of the property, while the leaser retains the title to the property. For the purpose of the program, the debt is the present value (at the inception of the lease) of all lease payments expected to be made during the period of the agreement excluding those payments that cover the operation, repair, or maintenance of the property.

- Arrears, penalties, and judicially awarded damages arising from the failure to make payment under a contractual obligation that constitutes debt are debt. Failure to make payment on an obligation that is not considered debt under this definition (e.g. payment on delivery) will not give rise to debt."

- $\quad$ Adjustments. (i) Previously contracted debt that has been rescheduled will be excluded from the definition of "new debt" for the purposes of this performance criterion; (ii) excluded from the limits are purchases from the IMF Stand-By Arrangement and bilateral official loans extended and earmarked for payments on foreign deposit guarantees; (iii) changes in the stock of nonresident holding of medium and long-term debt in krona will also be excluded from definition of new debt; and (iv) arrears arising from intervened banks will be excluded.

14. Supporting material: Details of all new commitments and government guarantees for external borrowing, with detailed explanations, will be provided by the MoF to the IMF on a monthly basis within two weeks of the end of each month. Data will be provided using the actual exchange rates in effect at the time of contract or guarantee.

\section{F. Ceiling on the Stock of Central Government Short-Term External Debt}

15. Definition: The limit on short-term external debt applies on a continuous basis to the stock of short-term external debt in foreign currency owed or guaranteed by the central government of Iceland, with an original maturity of up to and including one year. It applies to debt as defined in paragraph 10 above. Excluded from the limit are any rescheduling operations (including the deferral of interest on commercial debt) and nonresident holding of short-term debt in krona. Debt falling within the limit shall be valued in U.S. dollars at the time the contract or guarantee becomes effective. 
16. Ceiling on the accumulation of new external payments arrears on external debt contracted or guaranteed by central government from multilateral or bilateral official creditors. This performance criterion applies on a continuous basis. External payment arrears consist of external debt service obligations (principal and interest) falling due after October 20, 2008, and that have not been paid at the time due, taking into account the grace periods specified in contractual agreements. Data will be provided on a monthly basis with a lag of no more than 20 days.

\section{G. Reporting Requirement for Financial Institutions in the Winding-up Process}

17. The CBI will provide to the IMF data reports from all financial institutions in the winding-up process on a quarterly basis. The reports will be in the format according to the CBI reporting template agreed with the IMF. The required data will allow the CBI and the IMF to track asset recovery and payout to creditors against their claims for both domestic and external assets and the cross-border movement of the proceeds.

Table 3. Program Exchange Rates

\begin{tabular}{lll}
\hline Icelandic króa per U.S. dollar & Icelandic króa per euro & Icelandic króa per pound \\
113.9 & 150.5 & 193.6 \\
\hline
\end{tabular}




\section{ATTACHMENT III. ICELAND: FUND RELATIONS}

(As of February 28, 2010)

I. Membership Status: Joined: December 27, 1945; Article VIII

II. General Resources Account:
Quota

Fund holdings of currency

Reserve position in Fund

Holdings Exchange Rate

III. SDR Department:

Net cumulative allocation

Holdings

IV. Outstanding Purchases and Loans:

Stand-By Arrangements
SDR Million

117.60

763.97

18.63

SDR Million

112.18

88.77

SDR Million

665.00
Percent Quota

100.00

649.63

15.84

\section{Latest financial Arrangements:}

\begin{tabular}{ccccc}
\hline Type & Date of & Expiration & Amount Approved & Amount Drawn \\
& Arrangement & Date & (SDR million) & (SDR million) \\
Stand-By & Nov 19, 2008 & May 31,2011 & $1,400.00$ & 665.00 \\
\hline
\end{tabular}

VI. Projected Payments to the Fund (SDR Million; based on existing use of resources and present holdings of SDRs):

\begin{tabular}{lccccc} 
& \multicolumn{5}{c}{ Forthcoming } \\
\hline & 2010 & 2011 & 2012 & 2013 & 2014 \\
Principal & & & 280.00 & 332.50 & 52.50 \\
Charges/Interest & 11.81 & 15.80 & 12.76 & 4.27 & 0.52 \\
\cline { 2 - 6 } Total & 11.81 & 15.80 & 292.76 & 336.77 & 53.02 \\
\hline
\end{tabular}

VII. Implementation of HIPC Initiative: Not applicable

VIII. Exchange Rate Arrangements: The Icelandic krona is floating effective October 2008. Iceland has accepted Article VIII, Sections 2(a), 3, and 4 obligations, but maintains an exchange restriction arising from limitations imposed on the conversion and transfer of interest on bonds (whose transfer the FX rules apportion depending on the period of the holding), whose retention has been approved by the Executive Board (Decision No. 14445-(09/106). In addition, Iceland has in place measures that constitute exchange restrictions imposed for security reasons related to financial transactions based on UN Security Council Resolutions. Exchange restrictions arising from the rationing of 
foreign exchange in respect of certain imports were in place at the time of approval of the Stand-By arrangement, but they were lifted in November 2008. The restriction arising from the limitations on the transfer of the indexed portion of amortized principal on bonds that was in place at the time of the first review under the Stand-By Arrangement was lifted on October 31, 2009.

IX. Safeguards Assessment: A first-time safeguards assessment of the CBI has been conducted in connection with the current Stand-By Arrangement. The assessment concluded that the CBI's overall control environment was broadly appropriate for a small central bank, with good controls in the accounting and financial reporting area. The CBI's external and internal audit procedures practices were not found to be in line with international practices, however, and the foreign reserves management area would benefit from development. Recommendations were made to strengthen the external audit process, improve the independence of the internal audit function, establish procedures and controls for the data reporting to the Fund, and review and further develop the CBI's foreign reserves management operations. The authorities have already taken steps to implement these recommendations, notably by appointing an international audit firm under the auspices of the Auditor General to conduct annual external audits of the CBI in line with international standards, starting with financial year 2009. Internal audit was also outsourced.

X. Last Article IV Consultation: Discussion for the 2008 Article IV Consultation was held in Reykjavik during June 23-July 4, 2008. The Staff Report (Country Report No. 08/367) was considered by the Executive Board on September 10, 2008. Article IV Consultations with Iceland are currently held on the 12-month cycle.

XI. Discussions for the Second Review of the Stand-By Arrangements. Discussions were held during December 1-14. The mission met with the Prime Minister, Jóhanna Sigurðardóttir; the Minister of Finance, Steingrímur J. Sigfússon; the Governor of the Central Bank of Iceland, Már Guðmundsson; the Minister of Business Affairs, Gylfi Magnússon; the Minister of Social Affairs, Árni Páll Árnason; and other senior officials; as well as parliamentarians, CEOs of the new banks and Icelandic corporations, the employers federation and labor unions, representatives of creditors, and academics. The staff team comprised M. Flanagan (head), W. Lam and W. Maliszewski (all EUR); M. Chivakul (EUR/SPR), G. Everaert, and I Petrova (FAD); K. Christopherson (LEG); L. Cortavarria (MCM); and P. Dohlman (SPR). The mission overlapped with technical assistance missions by MCM and LEG. The mission was assisted by F. Rozwadowski and E. Karlsdóttir from the resident representative office. B. Olafsson (OED) attended many meetings. 


\section{Technical Assistance:}

\begin{tabular}{lll}
\hline Department & Purpose & Date \\
\hline MCM & Foreign exchange regulation & November 2008 \\
FAD & Budget framework & January 2009 \\
MCM & Monetary operations & February 2009 \\
MCM & Capital account liberalization & February 2009 \\
LEG & Debt restructuring & February 2009 \\
FAD & Budget framework & May 2009 \\
MCM & Capital account liberalization & June 2009 \\
MCM & Public debt management & August 2009 \\
MCM & Monetary operations & September 2009 \\
STA & Monetary and financial statistics & September 2009 \\
FAD & Cash management & September 2009 \\
MCM & Public debt management & October 2009 \\
MCM & Monetary operations & December 2009 \\
MCM & Capital account liberalization & March 2010 \\
\hline
\end{tabular}

XIII. Resident Representative:

Mr. Franek Rozwadowski assumed the position in March 2009. 


\section{IMF Completes Second Review under Stand-By Arrangement for Iceland, Extends the Arrangement, Rephases Access and Approves US \$160 Million Disbursement}

The Executive Board of the International Monetary Fund (IMF) today completed the second review of Iceland's economic performance under a program supported by a Stand-By Arrangement (SBA).

At the request of Iceland's authorities, the Board also extended the SBA by three months to August 31, 2011 to compensate for delays in completing this review, and approved the rephasing of the undisbursed amounts over the remainder of the arrangement. The completion of the second review enables the immediate disbursement of an amount equivalent to SDR 105 million (about US\$160 million), bringing total disbursements under the program to an amount equivalent to SDR 770 million (about US\$1.2 billion).

"The crisis has taken a heavy toll on Iceland and its citizens, but I am confident that the policies and financing now in place will ease the burden of adjustment and help Iceland's economy stage a recovery in the second half of 2010," IMF Managing Director Dominique Strauss-Kahn and Chair, said.

"Looking ahead, the IMF will continue to support Iceland's efforts to address this crisis in any way it can," Strauss-Kahn added.

The SBA was approved on November 19, 2008 (see Press Release No. 08/296) for an amount equivalent to SDR 1.4 billion (about US $\$ 2.1$ billion) and was subsequently extended to May 31, 2011 (see Press release No 09/375). The arrangement entails exceptional access to IMF resources, amounting to 1,190 percent of Iceland's quota.

Following the Executive Board's discussion on Iceland, Mr. Strauss-Kahn stated:

"The crisis has taken a heavy toll on Iceland, but the policies and financing now in place will ease the burden of adjustment and help the economy stage a recovery in the second half of 2010. Looking ahead, the IMF will continue to support Iceland's efforts to address this crisis

Washington, D.C. 20431 • Telephone 202-623-7100 • Fax 202-623-6772 • www.imf.org 
in any way it can. Program policies are geared to address the headwinds from distressed private sector balance sheets, and with determined policy implementation both the recovery and durable reductions in Iceland's debt burden can be achieved.

"The budget for 2010 strikes an appropriate balance between adjustment to secure public debt sustainability and supporting the recovery. The fiscal focus will now shift towards identifying remaining needed fiscal adjustment measures for the medium-term, and to establishing a stronger fiscal-federal framework. The new public debt management strategy is expected to realize durable reductions in rollover risk.

"Monetary policy will continue to focus on preserving currency stability to support program inflation and growth targets. In light of uncertainties about the timing of new external borrowing, capital account liberalization will remain on hold. In the event of further upward pressure on the krona, stronger emphasis should be placed on reserve accumulation.

"Progress continues towards restructuring the financial system. Key near-term priorities include recapitalizing the remaining savings banks by end-May, identifying any needed steps to reinforce the non-bank financial sector, and continued operational restructuring of banks. These efforts will be complemented by strengthening the framework for regulation and supervision.

"Private sector debt restructuring remains a key means to address macroeconomic and financial sector risks. Measures taken to date have established a framework and greater incentives will be built in for voluntary restructurings. Additional tools will help the insolvency regime and court system to support a large volume of private restructurings, if needed.

Iceland's ability to fully implement the program is dependent on mobilizing bilateral external financing and regaining confidence of the markets. Iceland's commitment to continue with best faith efforts to reach an agreement with the Netherlands and the United Kingdom regarding Icesave deposits is welcome, and all parties are called upon to come to a final agreement expeditiously." 


\section{Statement by Per Callesen, Executive Director for Iceland and Bjorn Olafsson, Senior Advisor to Executive Director April 16, 2010}

The economy of Iceland has performed better than previously envisaged, and policy implementation of our IMF program has continued on a steady course despite delays in reviews. All relevant performance criteria for the Second Review have been met. Three program benchmarks have been completed, and the fourth is near completion.

Our Icelandic authorities remain fully committed to the program and place great emphasis on restoring confidence in the economy and repairing the widespread damage inflicted by the currency and banking crises. To this end, the following items continue to play a key role: currency stability; reducing inflation and anchoring inflation expectations; containing and reversing the negative effects on the real economy; debt sustainability; restoring viable and functioning financial institutions and markets.

The authorities have also taken steps to build the longer-term foundations of a sound and healthy financial system and economy. As part of that process, a Parliamentary Special Investigative Commission reported earlier this week on the causes of the financial crisis in Iceland, named responsible parties, submitted potential criminal cases to a special prosecutor, and made several suggestions on institutional reforms. Widespread general discussion on the findings is in its early stages.

The authorities continue to be engaged in good faith negotiations with the authorities of the United Kingdom and the Netherlands in order to come to an agreeable conclusion on the Icesave issue in the near future. Successful implementation of our program is dependent on access to the external financing committed under the program. We firmly expect to meet the requirements set by some of our bilateral partners for access to this financing. Our Icelandic authorities wish to reaffirm that Iceland will honor its obligations with regard to the insured retail depositors of the intervened banks.

\section{Outlook}

The key macroeconomic indicators in Iceland's economy have come out better than expected. The contraction in real GDP growth in 2009 was $6 \frac{1}{2}$ percent but was originally projected at close to 10 percent. Unemployment appears to have stabilized around 8-10 percent but was expected to rise as high as 11 percent. The trade balance has been positive since the fourth quarter of 2008 and was 8 percent of GDP in 2009, as the tradable sector has benefited from currency depreciation and higher export prices. GDP is expected to contract by about $2 \frac{1}{2}-3$ percent in 2010 , but growth should be positive in 2011 . The contraction this year is generally in line with previous estimates, with somewhat more robust consumption offsetting further delays in energy-intensive investment projects. In general, the main factors 
contributing to growth continue to be net exports in the near term, followed by a gradual recovery of domestic demand.

\section{Fiscal policy}

General Government debt is lower than projected. At year-end 2009, the debt ratio was 105 percent of GDP, or about 15 percentage points less than previously envisaged. Lower public debt figures and an improved outlook for public debt sustainability have provided fiscal policy with greater scope to support the economic recovery. Thus the general Government primary deficit adjustment, on a national accounts cash basis, will be just above 4 percent instead of 5 $\frac{1}{2}$ percent of GDP in 2010, delivering a general Government primary deficit level of just below 3 percent of GDP. The authorities expect local governments, in the aggregate, to maintain broadly the same primary balance in 2010 as in 2009 , and their budget plans are in line with this expectation. To achieve our fiscal target, we therefore envisage a central government primary adjustment of 4.4 percent of GDP, achieving a primary deficit level of 2.4 percent of GDP in 2010 .

Our authorities remain fully committed to tackling the deficit head-on. The consolidation path continues to remain front-loaded and should deliver end-2014 general Government debt level around 90 percent of GDP, with a structural balance at around 3 percent of GDP.

Debt management is an intrinsic part of a more robust fiscal stance. To this end, the authorities aim to look at the financing of the deficit and refinancing of debt coming due in conjunction. A comprehensive debt management strategy has been set out, entailing diversification across instruments and investor base, prudent management of rollover risks, and a stronger framework for managing contingent liabilities.

\section{Monetary policy}

Temporary capital account restrictions were imposed in early December 2008 to stabilize the currency and prevent damaging capital outflows. The króna has been relatively stable since mid-2009, and since January 2010 it has strengthened against the euro by about 5 percent. At the same time, the central bank stepped down its sales of foreign currency in support of the króna and has not intervened in the FX market since early November 2009. In late October to early November 2009, capital controls enforcement was improved. Although the swing of the underlying current account into surplus has underpinned currency stability, to a large extent it can be contributed to this stricter enforcement of the capital controls. Most important in this regard is the fact that the link between the onshore and offshore markets for króna has been largely severed. The authorities remain committed to lifting the capital controls, as soon as conditions permit, in a manner that does not undermine the króna.

The Monetary Policy Committee (MPC) has gradually lowered central bank interest rates without undermining either exchange rate stability or the prospects of relatively rapid disinflation in the coming months. The MPC has also realigned market interest rates within a 
narrower corridor, partly through issuing CDs. These measures have enhanced the effectiveness of interest rate policy.

CPI inflation is expected to drop below 5 percent by end-2010 and fall to the 3-4 percent range in 2011. The effect of the stability of the króna and a significant slack in the economy will contribute to reduced price pressures next year. Risks to the inflation outlook emanate from possible second-round effects of exchange rate fluctuations, wage pressures in the tradable sectors, and potentially persistent inflation expectations.

\section{Financial sector policies}

Our authorities consider completion of financial sector restructuring a key near-term priority in order to set the stage for durable renewal of lending, underpin confidence in the banks, and pave the way for private sector debt restructuring.

All three large commercial banks have now been recapitalized, and a majority share has been acquired by foreign creditors in all but NBI (New Landsbanki). A prerequisite for the review was the recapitalization of NBI to 12 percent of Tier 1 capital to risk-weighted assets. The level of public debt has been lowered from initial expectations, with the impact of bank capitalization as reflected in the sale of equity to creditors in those two banks.

With the above measures in place, the focus is now on the need to finalize savings bank recapitalization. Full recapitalization of the savings banks is underway, and its completion has been set for the end of May. Our authorities have proposed the recapitalization of the two largest savings banks, Sparisjóðurinn í Keflavík and Byr, as a new structural benchmark for end-May 2010. If necessary, public funds will be used up to the limits defined in the Emergency Act, and all fit-and-proper criteria will be adhered to, although the authorities are committed to avoiding socialization of private sector losses.

Some challenges remain with regard to non-deposit taking institutions. Among them is the Housing Financing Fund (HFF), which has total assets amounting to approximately 50 percent of GDP. However, the HFF is considered to have better overall mortgage portfolio quality than the banks, as it did not engage in the riskier end of mortgage lending.

As a prudential measure, these institutions will be required to demonstrate that their business plans are sufficiently robust to maintain or restore their solvency and viability without Government support. The FME will review these plans and require improvements where necessary. This is proposed as a structural benchmark for the end of August 2010. For these private undertakings, the authorities remain committed to zero absorption of losses and fair treatment of creditors according to applicable law. Our authorities will also ensure that the HFF is subject to prudential rules similar to those governing other financial intermediaries.

From the time of the crisis, it has been the authorities' firm goal to strengthen regulatory and supervisory practices, both in the near term and over a longer horizon. To this end, several 
draft bills have been submitted to Parliament. We expect the draft legislation addressing deficiencies in the bank regulatory framework to be passed by the end of June. The legislation will improve risk management systems and governance in banks, strengthen provisions on large exposures and connected- and related-party lending, enhance fit-andproper requirements for major shareholders, and grant the FME discretionary powers to act on key fronts.

The authorities have also proposed engaging in an assessment of compliance with the revised Basel Core Principles and formulating a strategic plan to address identified weaknesses, for publication by the end of March 2011. We propose this as a new structural benchmark.

\section{Private sector debt restructuring}

The restructuring of private sector debt is an immediate priority, as it will support fiscal consolidation, contribute to a reduction in external debt, and counterbalance macroeconomic headwinds. The key criteria are well targeted measures with limited fiscal costs. New information about private sector balance sheets suggests that vulnerabilities for the economy may be slightly less than previously perceived; however, there is a pressing need to reduce debt overhang and support growth, as high levels of household and corporate debt are weighing on domestic demand. Corporate debt restructuring would help prevent the exit of viable but over-leveraged companies and boost corporate investment.

The tools that are now being put in place are extensive and broad in scope. A comprehensive framework is being established for household debt restructuring. Within this scheme, emphasis has been placed on access to information, the possibility of payment smoothing, and voluntary workouts, as well as access to court-assisted processes. The passage of legislation to strengthen this framework is proposed as a structural benchmark for the end of June 2010. The necessary measures will also be taken to ensure that the system has enough administrative capacity to process workouts, although additional fiscal costs are not expected.

Measures have also been taken to support and create incentives for voluntary corporate restructuring. Financial institutions are required by law to submit internal guidelines for debt restructuring, which the FME will evaluate and approve. The guidelines include criteria under which loan terms can be altered, criteria to evaluate a debtor's assets and liabilities, and criteria to evaluate a debtor's ability to service debt based on expected future income and cash flow. Incentives include a bill amending the Act on Financial Undertakings, which ensures that unrestructured loans are reflected in banks' books and provisions on a timely basis.

Debt restructuring in the corporate sector will also be facilitated by ensuring that tax treatment of debt write-offs does not complicate restructuring. The insolvency regime will 
also be refined, and amendments are expected to be passed by the end of June. The capacity of the institutional framework to process cases will also be expanded by increasing the number of judges and assistant judges in the court system.

As a final note, our Icelandic authorities would like to express their gratitude for the dedication and professional advice of the Fund's staff, who put in countless hours of hard work in support of Iceland's program. 